\author{
by \\ Syed M. Raza Bokhari \\ M.Phil., University of the Punjab, 2006 \\ A thesis \\ presented to Ryerson University \\ in partial fulfillment of the \\ requirements for the degree of \\ Master of Applied Science \\ in the Program of \\ Environmental Applied Science and Management
}

Toronto, Ontario, Canada, 2017

(C) Syed M. Raza Bokhari 2017 


\section{AUTHOR'S DECLARATION}

I hereby affirm that I am the sole author of this thesis. This is a true copy of the thesis, including any required final revisions, as accepted by my examiners.

I authorize Ryerson University to lend this thesis to other institutions or individuals for the purpose of scholarly research.

I further authorize Ryerson University to reproduce this thesis by photocopying or by other means, in total or in part, at the request of other institutions or individuals for the purpose of scholarly research.

I understand that my thesis may be made electronically available to the public. 


\title{
ABSTRACT \\ THE EFFECT OF ESSENTIAL OILS ON THE GROWTH OF BACTERIA FROM MUNICIPAL WASTEWATER TREATMENT
}

\author{
Syed M. Raza Bokhari \\ Master of Applied Science, Environmental Applied Science and Management, 2017 \\ Ryerson University.
}

Bacterial sensitivity to essential oils has been reported in the case of soil isolated bacteria, food isolated bacteria but there is little evidence available to support the fact that wastewater isolated bacteria show sensitivity to essential oils. Keeping in view this fact the present investigation aims to determine the wastewater isolated bacterial strains sensitivity to six commercially available plant essential oils including clove, cinnamon, oregano, tea tree, fennel, and wintergreen. The essential oils were tested against ten laboratory bacterial strains (Acinetobacter baumanii, Escherichia coli: DH5a, E.coli: AD202, Pseudomonas fluorescens, Pseudomonas poae, Pseudomonas putida, Staphylococcus aureus, and Stenotrophomonas maltophilia) (2) and ten wastewater isolated bacterial strains (Acinetobacter baumanii, Acinetobacter bouretii, Aeromonas hydrophila, E.coli, Enterobacter cloaceae, Flavobacterium branchiophilum, Klebsiella pneumoniae, Pseudomonas staurtii, Serratia fonticola, and Staphylococcus muscae) using the Kirby-Bauer disc diffusion assay, and the broth tube macrodilution MIC assay. The disc-diffusion assay showed that three of the oils, clove, cinnamon and oregano, were the most effective at inhibiting the growth of all the known single isolates. The broth tube MIC assay found that the WWTP isolated bacterial strains such as E. coli, Staphylococcus muscae, Enterobacter cloaceae, Acinetobacter baumanii were most sensitive to clove oil at MIC concentration $\leq 0.52 \mathrm{mg} / \mathrm{ml}$, cinnamon oil at MIC concentration $\leq 0.51 \mathrm{mg} / \mathrm{ml}$, and oregano oil MIC concentration $\leq 0.47$ $\mathrm{mg} / \mathrm{ml}$. Finally, wastewater microbial community samples from activated sludge, returned sludge and anaerobic digesters were reduced by $0 \%>94.24 \%, 46 \%>99 \%, 70 \%>97 \%$ percent when tested against clove, cinnamon, and oregano oils. 


\section{ACKNOWLEDGMENTS}

I would like to express my deepest gratitude to my Supervisor Dr. Kim Gilbride for her valuable suggestions and guidance in every step of my research and compilation of this manuscript. I appreciate her support during hard times especially when my son Ayaan remained very sick. This depicts her kindness and compassion. I would also like to thank Dr. Corey Searcy for his support during difficult times. I would also like to acknowledge Dr. Michal Bardecki and Dr. Lynda McCarthy for their valuable suggestions.

Special thanks to Mr. Amir Tehrani for cultures and all of my Lab fellows for their support. Last but not least a special thanks to my wonderful wife Faryal, kids Ayaan and Jia for their help and support to whom I am always indebted. Finally, I am thankful to my father Prof. Ashraf Shabbir Bokhari and my brother Dr. Ahmad Raza for their consistent prayers and encouragement. 


\section{DEDICATION}

This thesis is dedicated to my Champ syed Apaan Raza, who Gas been a source of inspiration for me always. 


\section{TABLE OF CONTENTS}

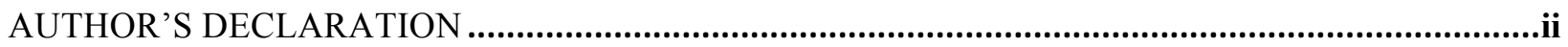

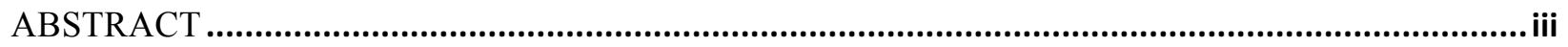

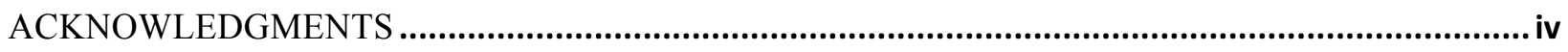

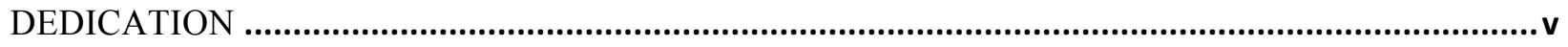

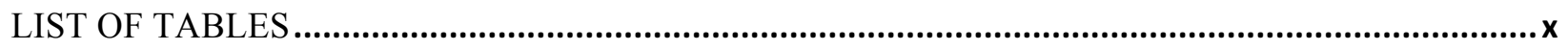

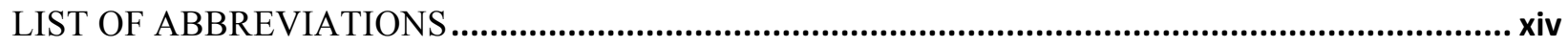

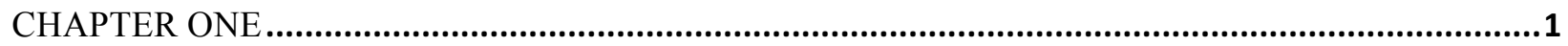

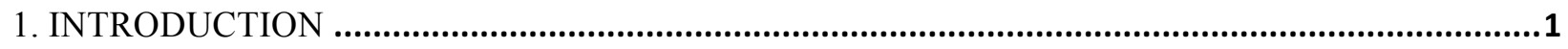

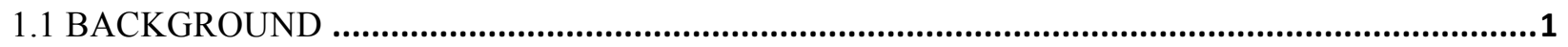

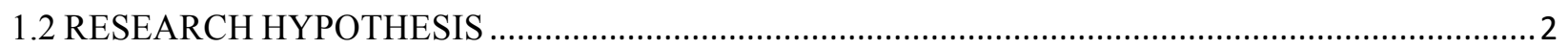

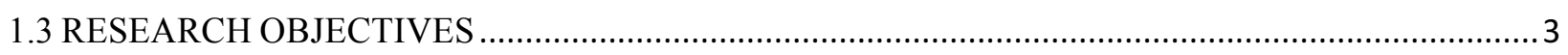

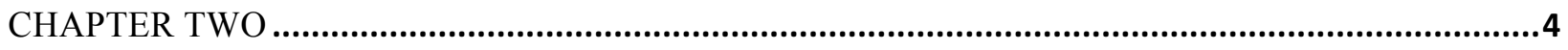

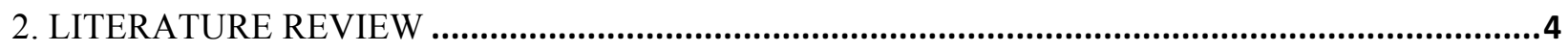

2.1 PREVALENCE OF MULTIDRUG RESISTANT BACTERIA IN WATER ENVIRONMENT .........4

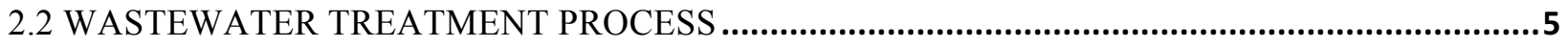

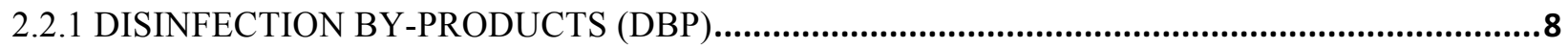

2.2.2 QUEST FOR ALTERNATIVE DISINFECTION ….................................................................10

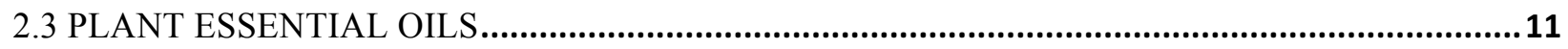

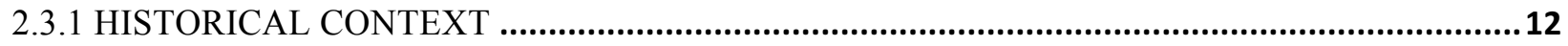

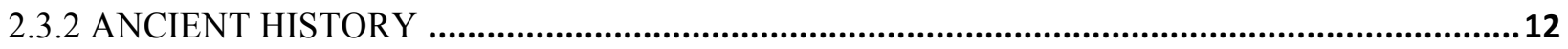

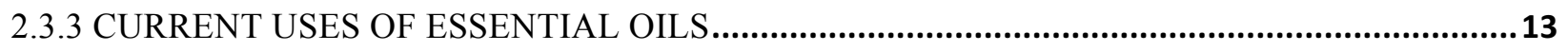

2.3.4 COMMERCIAL PRODUCTION PROCESS OF PLANT ESSENTIAL OILS..............................14

2.3.5. COMMERCIAL PRODUCTION OF PLANT ESSENTIAL OIL ANALYSIS ............................14

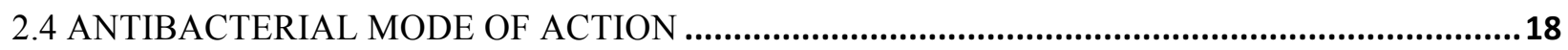




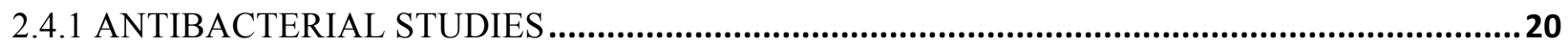

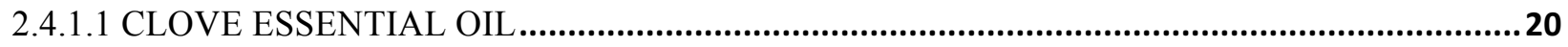

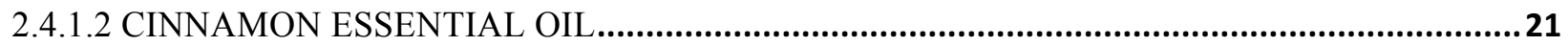

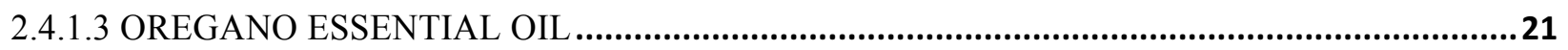

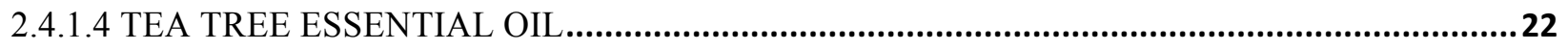

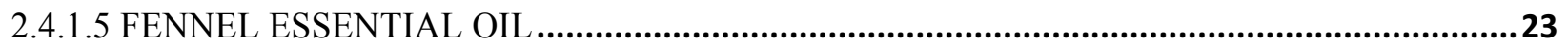

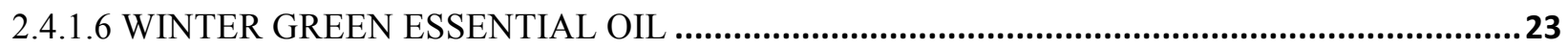

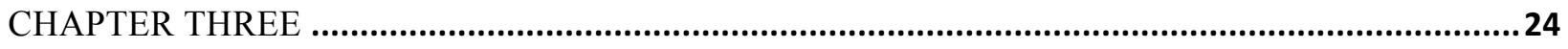

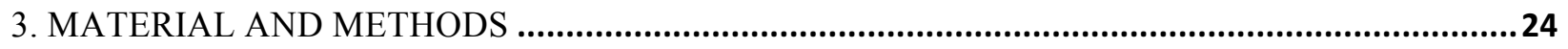

3.1 SOURCE OF EXPERIMENTAL BACTERIAL CULTURES.......................................................24

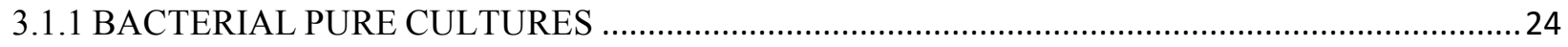

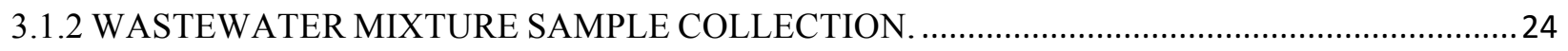

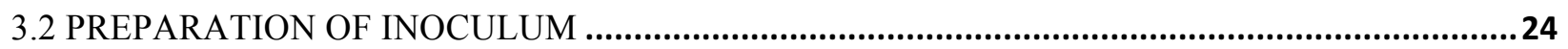

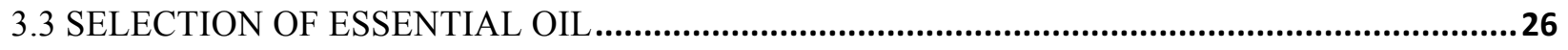

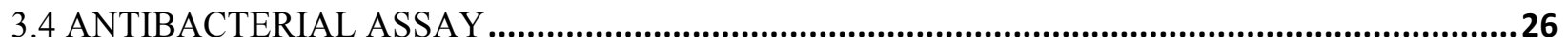

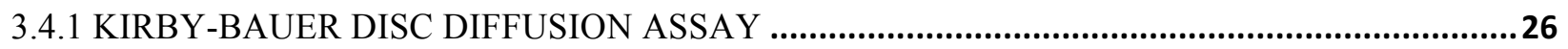

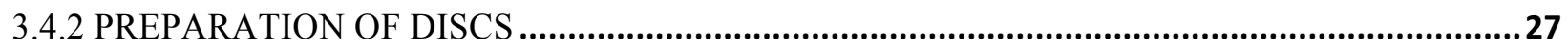

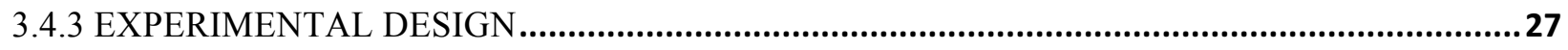

3.4.3.1 PRELIMINARY SCREENING OF ESSENTIAL OILS .........................................................27

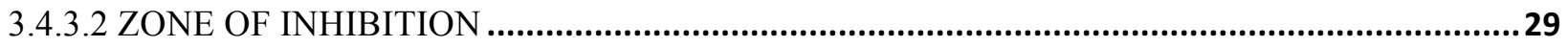

3.5 DETERMINATION OF MIC (MINIMUM INHIBITORY CONCENTRATION) ............................30

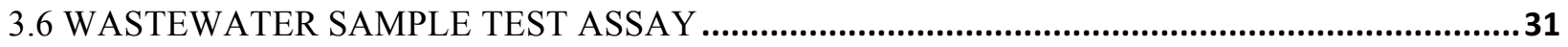

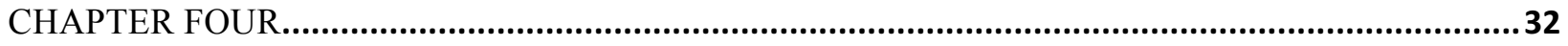

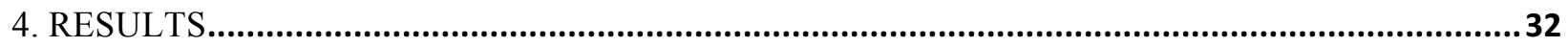

4.1 PRELIMINARY SCREENING OF PLANT ESSENTIAL OILS..................................................32

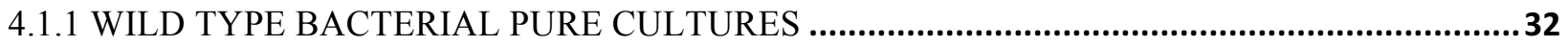


4.1.2 WASTEWATER ISOLATED BACTERIAL STRAINS ............................................................40

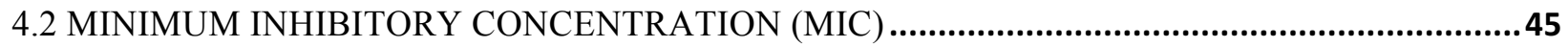

4.2.1 MINIMUM INHIBITORY CONCENTRATION OF CLOVE ESSENTIAL OIL ........................45

4.2.2 MINIMUM INHIBITORY CONCENTRATION OF CINNAMON ESSENTIAL OIL ..................45

4.2.3 MINIMUM INHIBITORY CONCENTRATION OF OREGANO ESSENTIAL OIL.....................45

4.3 GROWTH OF BACTERIA FROM WASTEWATER SAMPLES - PERCENTAGE REDUCTION

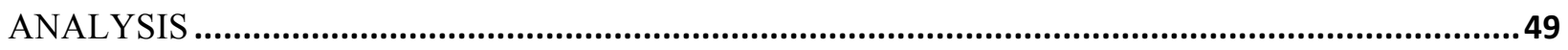

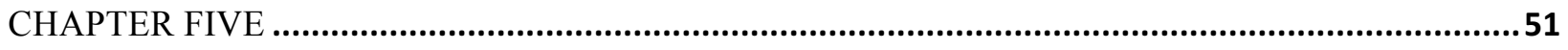

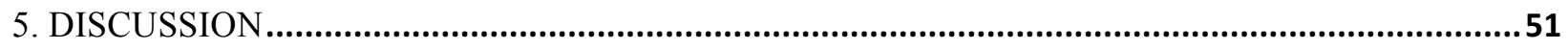

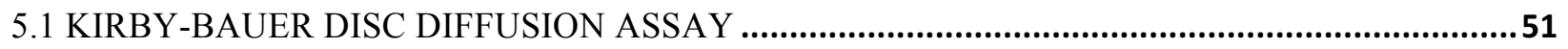

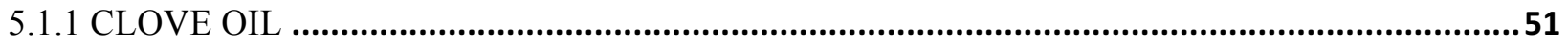

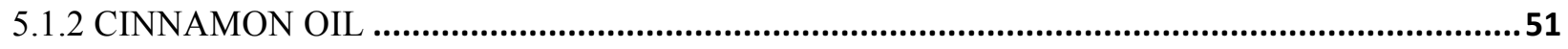

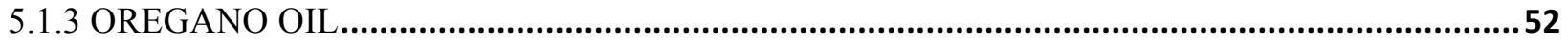

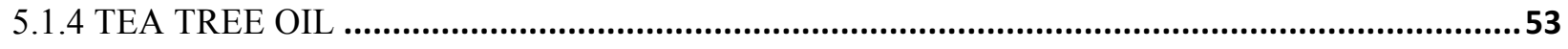

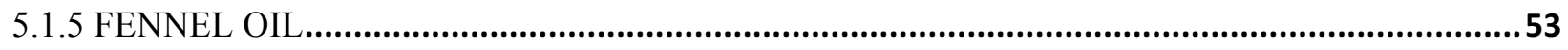

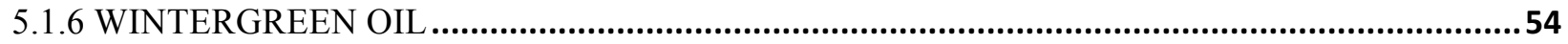

5.2 MINIMUM INHIBITORY CONCENTRATION ASSAY ....................................................54

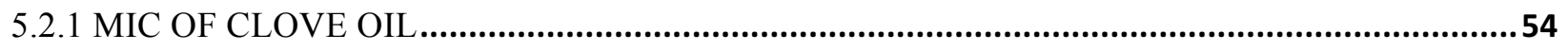

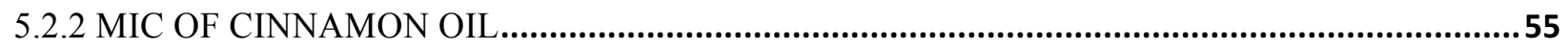

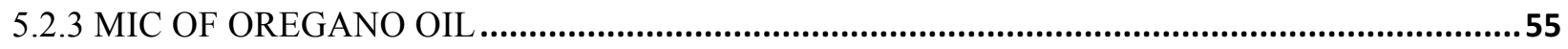

5.3 WASTEWATER SAMPLES BACTERIAL GROWTH REDUCTION PERCENTAGE ANALYSIS

.

6. CONCLUSION

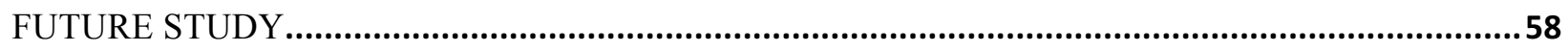

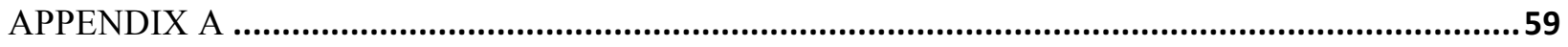

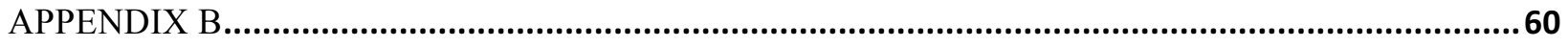




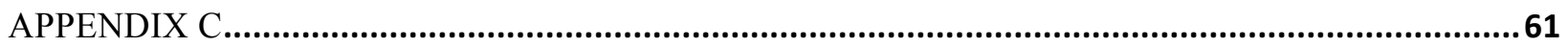

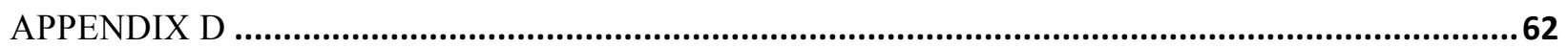

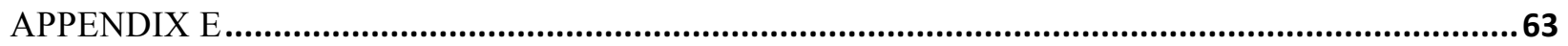

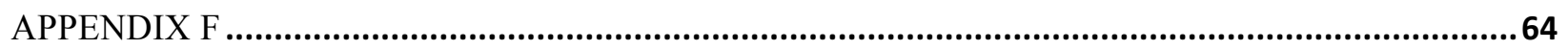

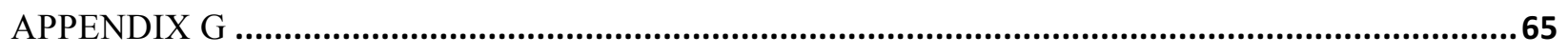

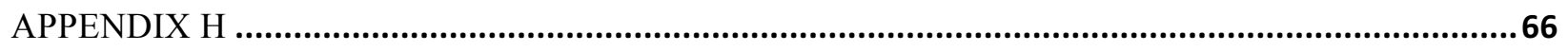

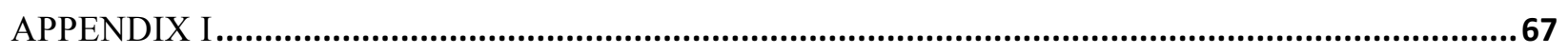

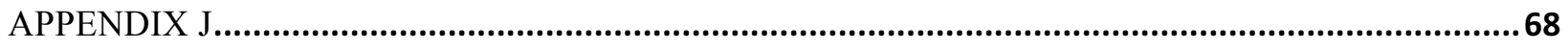

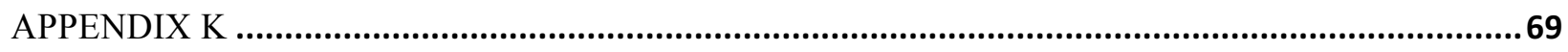

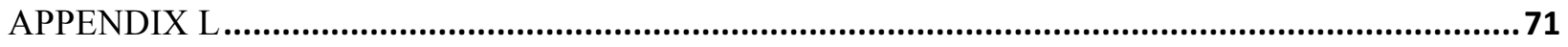

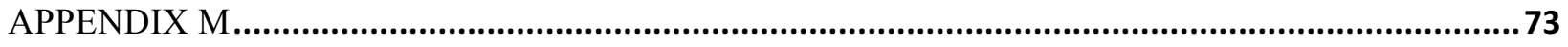

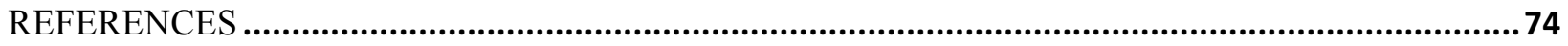




\section{LIST OF TABLES}

TABLE 2.1 WASTEWATER TREATMENT PLANT RESIDUAL CHLORINE.....................................

TABLE 2.2 SOME REGULATED AND NON-REGULATED DISINFECTION BYPRODUCTS IN

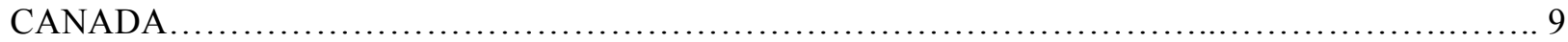

TABLE 2.3 PRODUCTION ANALYSIS OF IMPORTANT ESSENTIAL OILS (2008)................16

TABLE 2.4 ESSENTIAL OIL DISTRIBUTION, ANTIBACTERIAL COMPONENTS, LITERATURE

VALUE .18

TABLE 3.1 INVENTORY OF WILD TYPE AND WASTEWATER ISOLATED BACTERIAL CULTURE. .25

TABLE 3.2 PLANT ESSENTIAL OILS INVENTORY WITH SCIENTIFIC NAME, COMMON NAME,

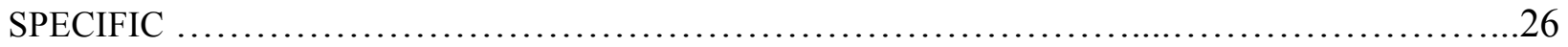

TABLE 3.3 BACTERIAL SENSITIVITY AND DIAMETER OF ZONE OF INHIBITION (13 MM; 6 $\mathrm{MM})$ .30

TABLE 4.1 WILD TYPE BACTERIAL SENSITIVITY TO CLOVE, CINNAMON, OREGANO, FENNEL, TEA TREE AND WINTER GREEN ESSENTIAL OILS DETERMINED BY DISC DIFFUSION ASSAY. .33

TABLE 4.2 WASTEWATER ISOLATED BACTERIAL SENSITIVITY TO CLOVE, CINNAMON, OREGANO ESSENTIAL OILS AS DETERMINED BY DISC DIFFUSION ASSAY.... 41

TABLE. 4.3 WASTEWATER ISOLATED BACTERIAL STRAINS SENSITIVITY TO CLOVE OIL BY EMPLOYING BROTH TUBE MACRO-DILUTION MIC ASSAY .46

TABLE. 4.4 WASTEWATER ISOLATED BACTERIAL SENSITIVITY TO CINNAMON OIL BY EMPLOYING BROTH TUBE MACRO-DILUTION MIC ASSAY

TABLE. 4.5 WASTEWATER ISOLATED BACTERIAL SENSITIVITY TO OREGANO OIL BY EMPLOYING BROTH TUBE MACRO-DILUTION MIC ASSAY. .48 
TABLE 4.6 WASTEWATER ISOLATED BACTERIAL SENSITIVITY TO CLOVE, CINNAMON AND OREGANO OILS BASED ON BROTH TUBE MACRO DILUTION MIC

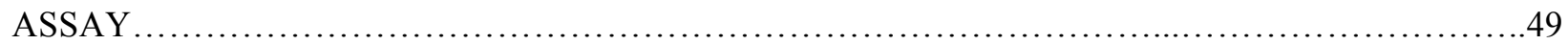

TABLE 4.7 THE PERCENT REDUCTION IN COLONY FORMING UNIT OF MIXED WASTEWATER BACTERIAL CULTURES DUE TO INHIBITION BY CLOVE OIL, CINNIMON OIL AND OREGANO

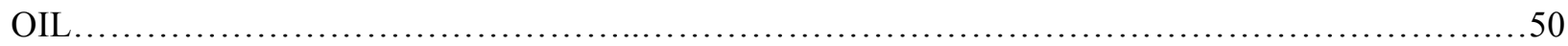




\section{LIST OF FIGURES}

FIGURE 1. CONVENTIONAL WASTEWATER TREATMENT FLOW DIAGRAM (WATER REUSE. 2010). 6

FIGURE 2. THE WASTEWATER TREATMENT PLANT PROCESSES STAGES. .6

FIGURE 3. STEAM DISTILLATION MANUFACTURING PROCESS ESSENTIAL OIL. (HTTP://WWW.UNION-NATURE.COM) 14

FIGURE 4. CANADIAN ESSENTIAL OIL EXPORTS (1998-2007). 15

FIGURE 5. STRUCTURAL FORMULA OF ESSENTIAL OILS CONSTITUENTS OF CLOVE, CINNAMON, OREGANO, FENNEL, TEA TREE, WINTERGREEN.

FIGURE 6. MODES OF ACTION OF PLANT ESSENTIAL OILS ON THE BACTERIAL CELL........19

FIGURE 7. EXPERIMENTAL DESIGN (A) KIRBY-BAUER DISC DIFFUSION ASSAY (B) MINIMUM INHIBITORY CONCENTRATION (C) KIRBY-BAUER DISC DIFFUSION ASSAY FOR WASTEWATER MIX BACTERIAL CULTURES. .28

FIGURE 8. ZONE OF INHIBITION MEASUREMENT .29

FIGURE 9. WILD TYPE BACTERIAL STRAIN SENSITIVITY TO CINNAMON ESSENTIAL OIL DETERMINED BY DISC DIFFUSION ASSAY

FIGURE 10. WILD TYPE BACTERIAL STRAIN SENSITIVITY TO CINNAMON ESSENTIAL OIL DETERMINED BY DISC DIFFUSION ASSAY .35

FIGURE 11. WILD TYPE BACTERIAL STRAIN SENSITIVITY TO OREGANO ESSENTIAL OIL DETERMINED BY DISC DIFFUSION ASSAY .36

FIGURE 12. WILD TYPE BACTERIAL STRAIN SENSITIVITY TO TEA TREE ESSENTIAL OIL DETERMINED BY DISC DIFFUSION ASSAY.

FIGURE 13. WILD TYPE BACTERIAL STRAIN SENSITIVITY TO FENNEL ESSENTIAL OIL DETERMINED BY DISC DIFFUSION ASSAY 
FIGURE 14. WILD TYPE BACTERIAL STRAIN SENSITIVITY TO WINTERGREEN ESSENTIAL OIL DETERMINED BY DISC DIFFUSION ASSAY …………………………………………...39

FIGURE 15. WASTEWATER ISOLATED BACTERIAL STRAINS SENSITIVITY TO CLOVE ESSENTIAL OIL DETERMINED BY DISC DIFFUSION METHOD. ............................................42

FIGURE 16. WASTEWATER ISOLATED BACTERIAL STRAINS SENSITIVITY TO CINNAMON ESSENTIAL OIL DETERMINED BY DISC DIFFUSION METHOD.

FIGURE 17. WASTEWATER ISOLATED BACTERIAL STRAINS SENSITIVITY TO OREGANO ESSENTIAL OIL DETERMINED BY DISC DIFFUSION METHOD ..............................................44 


\section{LIST OF ABBREVIATIONS}

AT

BOD

CBC

CEPA

CFU

DIG

DPB's Disinfection Byproduct

ECCC Environment and Climate Change Canada

EO's Essential oils

FDA Federal Drug and Food Administration

GRAS Generally recognized as safe

HAAs Haloacetic acid

HANs Haloacetonitrile

HKs Haloketones

MAC Maximum Acceptable Concentration

MOE Ministry of Environment

MIC Minimum Inhibitory Concentration

NCCLS National Committee on Clinical Laboratory Standards.

NDMA Nitrosodimethylamine

NOM Natural Organic Matter 


$\begin{array}{ll}\text { PAA } & \text { Peracetic Acid } \\ \text { RS } & \text { Return Sludge } \\ \text { TiO2 } & \text { Titanium Dioxide } \\ \text { THM's } & \text { Trihalomethane } \\ \text { TOC } & \text { Total Organic Carbon } \\ \text { TRC } & \text { Total Residual Chlorine } \\ \text { TSB } & \text { Tryptic Soy Broth } \\ \text { USEPA } & \text { United States Environmental Protection Agency } \\ \text { WWTP } & \text { Wastewater Treatment Plant } \\ \text { WHO } & \text { World Health Organization } \\ \text { WT } & \text { Wild-type }\end{array}$




\section{CHAPTER ONE}

\section{INTRODUCTION}

\subsection{Background}

Water is an invaluable natural resource for sustaining life. Globally, 1.8 billion individuals utilize contaminated drinking water sources (WHO 2011). The presence of contamination such as waterborne pathogens and chemical contaminants pose an invisible threat to the human population and can lead to various health complications (Fawell et al. 2003; Public Health Agency of Canada 2013). Urban runoff and wastewater treatment plants are primary contributors to the release of pathogenic bacteria and pharmaceuticals such as antibiotics (Rizzo et al. 2013). Moreover, the growing use of pharmaceutical products and their subsequent discharge into urban sewers may contribute to the increase in numbers of bacteria that develop resistance to antibiotics and metals due to mutations and horizontal gene transfer under this selective pressure (Davies \& Davies 2010). Developing countries are exposed to polluted water sources due to the discharge of approximately $95 \%$ of their urban sewage as untreated wastewater directly into surface waters used as drinking water sources for their population (Pimentel et al. 2004). In Canada, each year the Great Lakes waterways are recipients of billions of liters of untreated raw sewage which includes pharmaceuticals emerging from both point, as well as non-point sources, as a result of dumping, runoff, wastewater effluent breaches, and combined sewer overflow (Environment Canada 2001; Burton 2013). For example, as recent as November 2015, the City of Montreal dumped 8 billion liters of its raw sewage into the Saint Lawrence River possibly releasing pathogenic, antibiotic-resistant bacteria (CBC News 2015).

Currently, wastewater treatment plants use disinfectants such as chlorine, chlorine dioxide, and chloramines which are powerful oxidants to attenuate pathogenic organisms in the effluent. The standard contact time of chlorine with effluent is $30 \mathrm{~min}$ as per standard guidelines (MOE 2008). However, residual chlorine in water can react with natural organic matter (NOM) resulting in the formation of disinfection by-products (DBPs) such as trihalomethane, bromodichloromethane, bromoform, and chloroform. There are about 600 DBPs known so far whereas a countless number of them still need to be identified (Richardson et al. 2007; Health Canada 2008; Hrudey, S.E. 2008). During peak flow time primary effluent and secondary effluent 
bypass flows are disinfected using chlorine at levels ranging from $2.5 \mathrm{mg} / \mathrm{L}$ to $3.5 \mathrm{mg} / \mathrm{L}$ (City of Toronto 2010). Canadian Environmental Protection Act (CEPA) and Ontario guidelines, policies require chlorine levels below $0.02 \mathrm{mg} / \mathrm{L}$ to eliminate the risk of deleterious effect to aquatic life (Health Canada 1995; CEPA 1999; MOE 2008). The toxicity of very low levels of chlorine residuals to fish and marine life has become a concern to mitigate wastewater effluents a subsection wastewater system effluents regulation enacted under the Fisheries Act which is administered by ECCC (Environment and Climate Change Canada 2016). Studies have reported carcinogenic and deleterious effects of chlorinated wastewater effluents downstream from Canadian sewage treatment plants, demonstrating that levels in the effluent exceeding $0.02 \mathrm{mg} / \mathrm{L}$ may cause acute lethality to fish, and changes to the structure of the benthic invertebrate communities (Minister of Supply and Services 1993; Health Canada 1995; MOE 2008; Environment and Climate Change Canada 2016). Feasible alternatives to chlorine such as peracetic acid (PAA), ferrate, bromine compounds, pasteurization, ultrasonic cavitation, electron beam (E-Beam) and gamma irradiation, and photo-catalysis / titanium dioxide $\left(\mathrm{TiO}_{2}\right)$ have been studied and are under pilot studies. However, more research is needed to find disinfection products that are less toxic or biocontrol agents that are renewable, cost effective and environmentally friendly. Although chlorine is still considered the first choice for disinfection, it is important to examine additional technologies and additives that can be used to decontaminate water. Furthermore, since chlorine will most likely continue to be used, it is important to look at the synergy that these methodologies could have with chlorine use and the effect on pathogen dissemination and residual chlorine compounds in the water.

\subsection{Research Hypothesis}

Traditionally we have used chlorine as a primary choice disinfectant for water treatment, however, to increase the options available for water treatment other products need to be examined. Essential oils have been shown through the decades to have antibacterial activity and to be effective for food security and disinfection (Burt et al 2003; Winward et al 2008). Furthermore, they are natural products that are considered more environmentally friendly than chlorine. The goal of this research project is to determine whether plant essential oils can be used as an antibacterial agent to reduce or eliminate bacteria from the final effluent of an activated sludge treatment process in a municipal wastewater treatment facility. 
Hypothesis: It is hypothesized that six plant essential oils would have an inhibitory effect on ten bacterial pure cultures and ten wastewater isolated bacteria due to their antibacterial property. To determine their antibacterial activity against wastewater isolated bacteria standard bioassays were employed as suggested by NCCLS 2014 which are disc diffusion assay (qualitative analysis) and broth tube dilution assay (quantitative analysis). One may predict an alternative or additive antibacterial agent which is naturally driven from renewable resources such as plants.

\subsection{Research Objectives}

To address the goal of this project, the short-term objectives are:

Objective 1. To determine the antibacterial activity of essential oils against known bacteria. Six essential oils (oil of clove (Syzygium aromaticum), oil of cinnamon (Cinnamomum cassia), oil of oregano (Origanum vulgare), oil of tea tree (Melaleuca alternifolia), oil of fennel (Foeniculum vulgare) and oil of wintergreen (Gaultheria procumbens) were chosen and tested against 10 known wildtype bacterial pure cultures (Acinetobacter baumanii, E.coli, Pseudomonas fluorescens, Pseudomonas poae, Pseudomonas putida, Staphylococcus aureus and Stenotrophomonas maltophiles) and 10 wastewater isolates (Acinetobacter baumanii, Pseudomonas staurtii. Aeromonas hydrophila, E.coli, Klebsiella pneumoniae, Serratia fonticola, Staphylococcus muscae, Enterobacter cloaceae, Flavobacterium branchiophilum, Acinetobacter bouretii) that had been previously isolated from the wastewater activated sludge treatment process by our lab and identified. The Kirby-Bauer antimicrobial susceptibility test was used to determine the sensitivity of the bacteria to each oil at a predetermined concentration. The results will indicate the efficacy of each of the oils.

Objective 2: To determine the minimum inhibitory concentration (MIC) of the oils needed to cause a significant inhibition of bacterial growth. This was accomplished by using a 2-fold dilution series of three of the essential oils against the bacterial strains.

Objective 3: To determine the inhibitory activity of the essential oils against mixed wastewater microbial communities collected from various aeration tanks and digesters in the WWTP. The Kirby-Bauer susceptibility assay (objective 1) was used along with the MIC of the oils determined in objective 2 to measure the inhibition of the oils against the mixed bacterial communities from four aeration tanks (AT-2, AT-4, AT-6, AT-8), two anaerobic digesters (DG-1, DG-2) and a return sludge (RS). 


\section{CHAPTER TWO}

\section{LITERATURE REVIEW}

\subsection{Prevalence of Multidrug Resistant Bacteria in Water Environment}

The environmental balance of water bodies is being disturbed due to rapid urbanization in many parts of the world. Since urban populations tend to thrive near water bodies, they are considered responsible for the increasing amounts of contaminants such as pharmaceuticals, personal care products, organic matter, pathogenic bacteria and toxic compounds that enter our water system including wells, streams, lakes, and rivers (Ramaiah et al. 2002). In Canada, a recent study has shown that one in every five first nation reserves are affected by boil water advisories due to the unacceptable quality of drinking water contaminated with coliform as well as antibiotic resistant genes (Fernando et al. 2016).

Both surface water and groundwater in the province of Ontario are prone to contamination emerging from dumping, runoff, wastewater effluent breaches, and combined sewer overflow due to extensive land use by urban, industrial, rural, and agriculture within the Lake Ontario drainage basin (Hlavinek 2009). Every year the Great Lakes waterways are recipients of billions of liters of untreated sewage (Brubaker 2011). In Walkerton, Ontario, in 2000, a tragedy occurred due to contamination of well no.5 with Escherichia coli 0157: H7 and Campylobacter jejuni coming from runoff from a nearby cattle farm. About 2,300 individuals experienced gastroenteritis, 65 were hospitalized, 27 developed hemolytic uremic syndrome, and seven died (Hrudey et al. 2003). Similarly, the First Nations drinking water crises continue to pose a challenge as figures are gathered based on a water risk analysis model by the government which disclosed facts on 120 Ontario First Nation communities inspected for regional risk summary based on their water source and water treatment classification. The report summarized 158 water systems during an inspection and found that 72 were at high risk; 62 were considered medium risk and only 25 considered low risk (Murphy et al. 2015). Overall, many drinking water advisories are issued by Health Canada each year. For example, in 2011 alone, Ontario had 37 advisories, Alberta had 33 advisories, British Columbia had 31 advisories, and Saskatchewan had 20 drinking water advisories (Health Canada 2011). About $80 \%$ to $90 \%$ of all infectious diseases worldwide are due to waterborne pathogens (Epstein et al. 1994; Pimentel et al. 2007). Besides pathogens, pharmaceuticals are becoming emerging contaminants due to their excessive use in human and veterinary medicine (Fent et al. 2006). Pharmaceutical compounds are designed to target specific metabolic pathways 
in humans and animals for therapeutic benefits; however, their impact on non-target organisms has the possibility of becoming deleterious even at very low concentrations (Moldovan 2006). Municipal wastewater is one of the main pathways by which these compounds can enter into the environment (Ternes and Joss 2004). Growing use of pharmaceuticals and their discharge into urban sewage may contribute to the increase in numbers of bacteria that develop antibiotic resistance due to mutations and horizontal gene transfer under this selective pressure (Davies and Davies 2010). In many cases, it has been inferred that bacteria tend to acquire resistance to multiple antibiotics producing multidrug-resistant bacteria or super bugs.

Urban runoff and wastewater treatment plants are hotspots for the release of antibiotics and pathogenic bacteria (Rizzo et al. 2013). Bacteria have a tendency to acquire resistance to antibiotics by gene swapping that may transform them into antibiotic resistant cells (Baquero 2008). Currently, developing countries are exposed to polluted water sources due to the discharge of approximately $95 \%$ of their untreated urban raw sewage directly into surface waters affecting about $50 \%$ of their population (Pimentel et al. 2007). As some studies show notable bacteria can be detected in wastewater treatment plant samples such as Pseudomonas staurtii, Aeromonas hydrophila, E.coli, Klebsiella pneumoniae, Acinetobacter baumanii, Serratia fonticola, Staphylococcus muscae, Enterobacter cloaceae, Flavobacterium branchiophilum, Acinetobacter bouretii, Pseudomonas fluorescence, Staphylococcus aureus, Pseudomonas poae, Stenotrophomonas maltophiles and Pseudomonas putida (Gilbride et al. 2006; Helt 2012).

Canada has devised stringent laws and policies to protect water from the source to tap. These laws are in place to reduce the threat of water contamination from pathogenic bacteria emanating as a result of dumping, runoff, wastewater effluent breaches, and combined sewer overflow (Environment Canada 2015; Environment and Climate Change Canada 2016). Based on evidence-based studies it is indicated that surface water and ground water is prone to contamination by pathogenic or antibiotic resistant bacteria which justifies a search for new innovative, alternative, antibacterial agents, novel molecules to be explored which may inhibit the growth of pathogenic and multidrug-resistant bacteria (Djeussi et al. 2013; Galvao et al. 2012).

\subsection{Wastewater Treatment Process}

Wastewater is the water after usage from residential, industrial, institutional and commercial sources that enters the wastewater treatment plant for processing. The city of Toronto has four 
WWTPs that process nearly 340 million gallons of sewage a day. The increased volume of wastewater being produced in Toronto annually is partially due to the rise in the metropolitan population (City of Toronto, 2010). In conventional wastewater treatment, following an initial screening step, there are three main stages known as primary, secondary, and tertiary treatment (Fig. 1\&2).

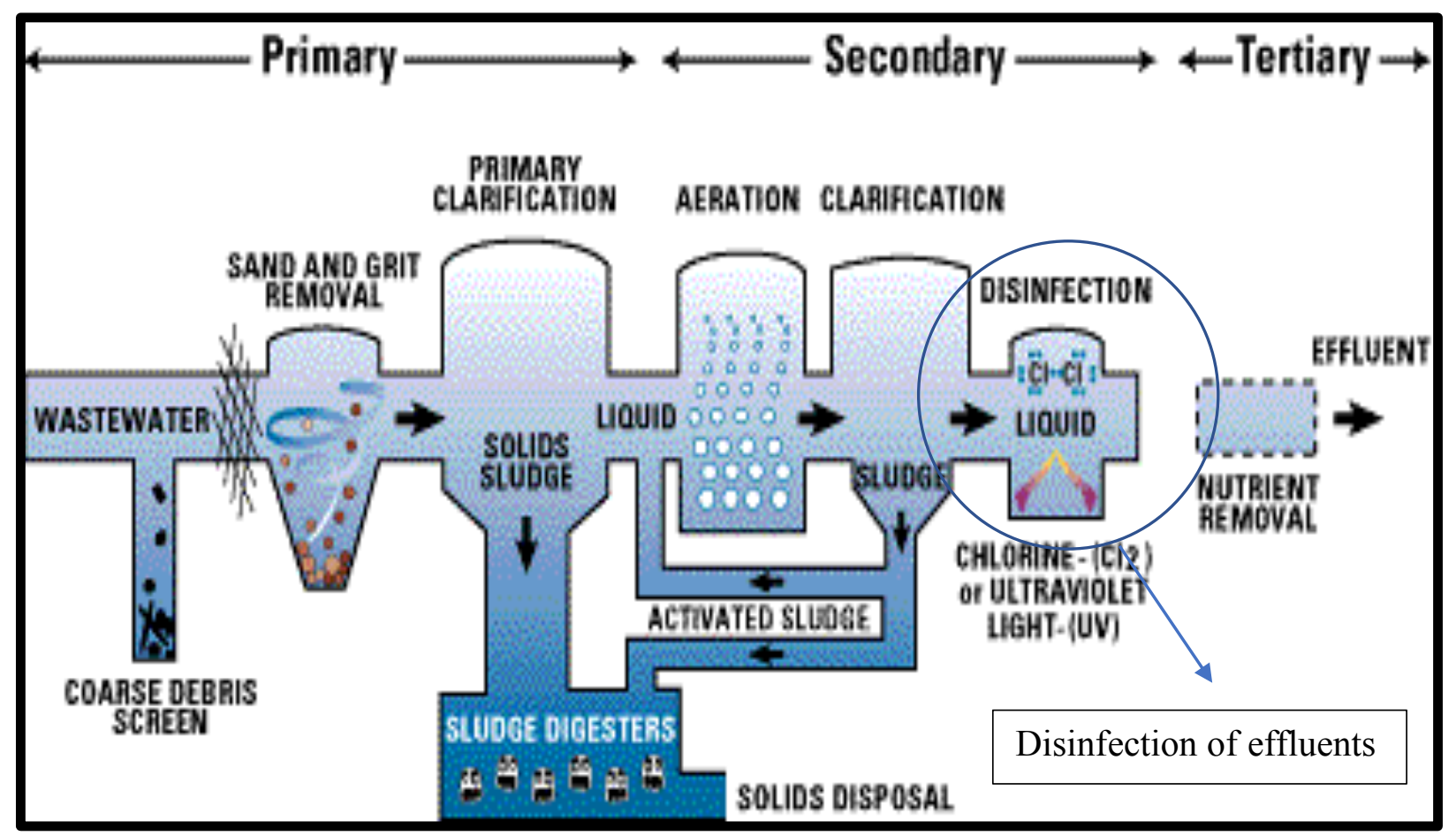

Figure 1. Conventional Wastewater Treatment Flow Diagram (Water Reuse. 2010).

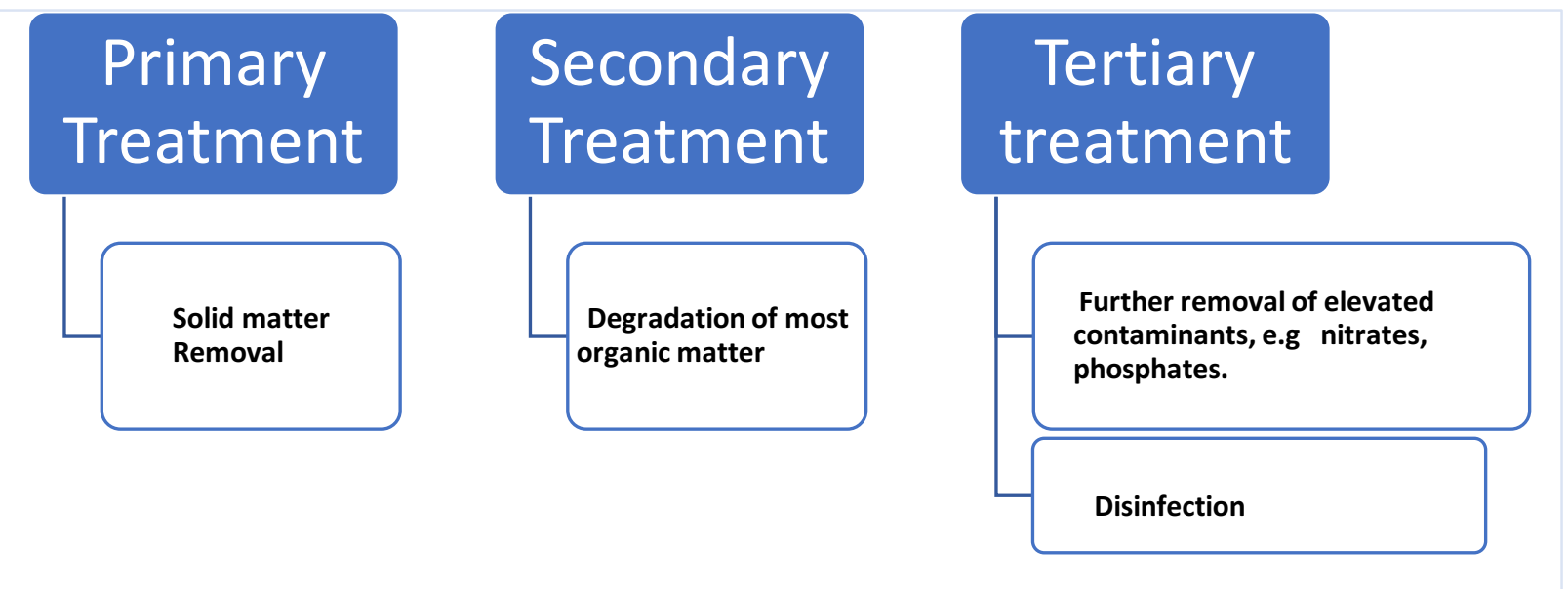

Figure 2. The Wastewater Treatment Plant Processes Stages. 
After the wastewater is collected from the various sources, it is carried through a series of pipes to a wastewater treatment plant. Here the wastewater is first subjected to a preliminary process that physically removes large debris using bars and screens. Subsequently, primary treatment can occur in large tanks where the flow of wastewater coming in is reduced to hold the wastewater in these tanks for several hours. Meanwhile, heavier solids such as sand, soil, rocks, grit and other materials will sink to the bottom and are separated and removed. The remaining liquid, called the primary effluent, is then subjected to the secondary treatment (biological treatment). In this stage, the wastewater is blended with a bacteria-rich sludge that can digest dissolved colloidal organic materials which remain in the primary effluent. Oxygen is usually added in this step to aid in microbial growth and metabolism. The main purpose of this step is to reduce the biochemical oxygen demand (BOD) of the effluent. Often the sludge produced during aerobic treatment can be further treated by anaerobic treatment. Tertiary treatment is further applied if the additional removal of nutrients such as phosphorus or nitrogen is needed. If not, the wastewater is subjected to a disinfection method such as chlorination or UV to reduce disease-causing bacteria before being released into surface waters. Roughly $70 \%-90 \%$ of facilities in North America use chlorine in one form or another (Health Canada 2008). Virtually all of the large plants discharging to Lake Ontario use chlorine, including all of the Toronto wastewater treatment plants (City of Toronto 2010). The disinfection of secondary effluent coming from clarifier in wastewater treatment plant is accomplished by dosing chlorine in any form (gas or liquid) and maintaining adequate contact time between the chlorine and the microorganisms. The chlorine residual remaining in the wastewater after a predetermined contact time can be measured to evaluate the effectiveness of the disinfection process since chlorine will be utilized if microorganisms remain in the effluent. The presence of a chlorine residual demonstrates that the microorganisms have been destroyed. The standard contact time of chlorine with effluent is $30 \mathrm{~min}$ as per standard guidelines (MOE 2008). Chlorine is known to have a deleterious effect on aquatic life at relatively low concentrations of $0.02 \mathrm{mg} / \mathrm{ml}$. The toxicity of very low levels of chlorine residuals to fish and marine life has become a concern. Studies have reported effects of chlorinated wastewater effluents downstream from Canadian sewage treatment plants causing acute lethality to fish, and changes to the structure in benthic invertebrate communities when total residual chlorine levels, rises above $0.02 \mathrm{mg} / \mathrm{L}$ (Supply and Services Canada 1993; MOE 2008; Health Canada 2013). These effects were 
noticeable and spanned up to 500 meters away from the outfall. Based on the deleterious effects on fish habitat, aquatic biota, chlorinated wastewater effluents have been enlisted in the Toxic Substances list of the Canadian Environmental Protection Act, 1999 (CEPA 1999). Accordingly, a guideline to maintain total residual chlorine (TRC) concentrations less than $0.02 \mathrm{mg} / \mathrm{L}$ in the wastewater effluent discharged to surface water has been established. During peak flow time primary and secondary effluent bypass flows are disinfected using chlorine. "At that point" the residual chlorine minimum limit of $0.02 \mathrm{mg} / \mathrm{L}$ level exceeds from $2.5 \mathrm{mg} / \mathrm{L}$ to $3.5 \mathrm{mg} / \mathrm{L}$ which is well above the standard set by CEPA and Fisheries Act (the City of Toronto. 2010; Environment and Climate Change Canada 2016).

Table 2.1. Wastewater Treatment Plant Residual Chlorine

\begin{tabular}{|c|c|c|c|c|c|}
\hline Year & $\begin{array}{l}\text { Average } \\
\text { Flow } \\
\text { (ML/d) }\end{array}$ & $\begin{array}{c}\text { Average } \\
\text { Chlorine } \\
\text { Consumption } \\
(\mathbf{k g} / \mathbf{d})\end{array}$ & $\begin{array}{c}\text { E.coli } \\
\left({ }^{1} \mathrm{CFU} / 100\right. \\
\mathrm{mL})\end{array}$ & $\begin{array}{c}{ }^{*} \text { CEPA/ } \\
\text { Fisheries Act } \\
\left({ }^{2} \text { MAC) }\right. \\
(\mathrm{mg} / \mathrm{L})\end{array}$ & $\begin{array}{c}\text { Residual Chlorine } \\
(\mathrm{mg} / \mathrm{L})\end{array}$ \\
\hline 2006 & 701 & 1,531 & 3 & 0.02 & 0.9 \\
\hline 2007 & 585 & 1,298 & 2 & 0.02 & 0.9 \\
\hline 2008 & 645 & 1,434 & 2 & 0.02 & 0.9 \\
\hline 2006-2008 & 644 & 1421 & 2 & 0.02 & 0.9 \\
\hline
\end{tabular}

Source: City of Toronto. 2010

\subsubsection{Disinfection By-Products (DBP)}

Chlorine has been the first choice disinfectant for over a century ago. Water supply systems in Canada utilize chlorine as a disinfectant (Health Canada 2008) based on it being cost effective

\footnotetext{
${ }^{1}$ CFU Colony Forming Unit

${ }^{2}$ MAC Maximum Allowable Concentration. Found in *CEPA, 1999; *Fisheries Act; MOE 2008; wastewater system effluent regulation 2016.
} 
while having good efficacy in removing a wide variety of pathogens. Studies show that chlorine as a strong oxidizing agent can react with natural organic matter (NOM) usually measured as total organic carbon (TOC) during or after the chlorination process of secondary effluent leaving minimum residual chlorine limits between $0.2 \mathrm{mg} / \mathrm{L}$ to $4 \mathrm{mg} / \mathrm{L}$ (Table.2.1). Perhaps the most challenging and daunting task ever faced by drinking water industry for the past three decades is the formation of DPB's (disinfection byproducts) as a result of disinfection of effluent by using chlorine and its precursors. There are about 600 DBP's known so far whereas a countless number of them still need to be identified (Richardson et al. 2007; Health Canada 2008; Hrudy, S.E. 2008). Chlorinated disinfection byproducts are a group of chemical substances that are unintentionally produced as a byproduct of the disinfection process mostly when the disinfectant reacts with naturally occurring organic matter (NOM) in surface water, or drinking water (Health Canada 2016). Some of the more common DBPs are trihalomethane (THMs), bromate, chlorite, nitrosodimethylamine (NDMA) and haloacetic acid (HAAs) which are regulated (Table 2.2). However, other DBPs are also formed that are not regulated in Canada so far such as iodo THMs, haloketones (HK's), haloacetonitriles (HAN's) (Richardson et al. 2007). In Canada, guidelines set standards for some of the DBP's with a maximum acceptable concentration (MAC) in water sources such as Trihalomethanes (THM4) $0.1 \mathrm{mg} / \mathrm{L}, \mathrm{N}-\mathrm{Nitrosodimethylamine} \mathrm{(NDMA)} 0.00004$ $\mathrm{mg} / \mathrm{ml} \mathrm{Haloacetic} \mathrm{acid} \mathrm{(HAA)} 0.08 \mathrm{mg} / \mathrm{L}$, Bromodichloromethane (BDCM) $0.01 \mathrm{mg} / \mathrm{L}$, and chlorite $1 \mathrm{mg} / \mathrm{L}$ (Health Canada 2014).

Table 2.2. Some Regulated and Nonregulated Disinfection Byproducts in Canada.

\begin{tabular}{|c|c|c|c|}
\hline $\begin{array}{l}\text { Regulated Disinfection } \\
\text { Maximum Acceptable } \\
\text { (MAC) in Canada. }\end{array}$ & $\begin{array}{r}\text { By-Products } \\
\text { Concentration }\end{array}$ & \multicolumn{2}{|c|}{$\begin{array}{l}\text { Non-Regulated Disinfection By-products } \\
\text { in Canada. (Maximum Acceptable } \\
\text { Concentration (MAC) in US). }\end{array}$} \\
\hline *Trihalomethanes (THMs) & $0.10 \mathrm{mg} / \mathrm{L}$ & **Haloacetonitriles (HANs) & $0.7 \mathrm{ng} / \mathrm{L}$ \\
\hline *Haloacetic acid (HAA) & $0.08 \mathrm{mg} / \mathrm{L}$ & $* *$ Haloketones (HKs) & $0.7 \mathrm{ng} / \mathrm{L}$ \\
\hline *Bromate & $0.08 \mathrm{mg} / \mathrm{L}$ & **Iodo THMs & ---- \\
\hline *Chlorite & $1 \mathrm{mg} / \mathrm{L}$ & & \\
\hline \multicolumn{4}{|c|}{ *N- nitrosodimethylamine (NDMA) $0.00004 \mathrm{mg} / \mathrm{ml}$} \\
\hline
\end{tabular}

Source: Regulated by Health Canada 2014*; Regulated by US EPA 2006**

Health Canada and provincial ministries reports are indicative of the fact that formation of disinfection by-products in Canadian water sources (Chowdhury et al. 2011). Studies suggest that disinfection by-products might be linked to possible cancer and mutagenic risk to animals and 
humans along with other health implications such as miscarriage, stillbirth, low birth weight, preterm delivery and cardiac anomalies (Ashbolt, 2004; Gopal et al. 2007; Richardson et al. 2007). Mode of exposure of disinfection by-product may be through ingestion of drinking water, inhalation, or dermal exposure (USEPA, 2006). Demographically approximately $75 \%$ of the population in Canada thrives in cities (Statistics Canada, 2008) where the main source of drinking water is municipal water system, therefore, much of the population may have been exposed to disinfection byproducts throughout their lifetime (Health Canada, 2008). The microbiological risk from improperly disinfecting the water, however, is more evident than presence of those disinfection by-products in drinking water (MOE, 2008; WHO, 2000) and therefore chlorine is still the disinfectant of choice. More recently, some municipal water systems have implemented alternative disinfection system such as UV disinfection system to reduce the exposure to DBPs without compromising proper disinfection (Health Canada, 2008; USEPA, 2006).

\subsubsection{Quest for Alternative Disinfection}

Based on the literature published so far Epstein et al. 1994; Fawell et al. 2003; Ashbolt, 2004; Gopal et al. 2007; Richardson et al. 2007; Pimentel et al. 2007; Hrudy, S.E. 2008; Brubaker 2011; Chowdhury et al. 2011 surface water and groundwater can be contaminated by pathogenic or antibiotic resistant bacteria and high chlorine residual along with formation of disinfection byproducts has become emerging challenge for regulatory authorities and water industries, in view

of above facts it is justified to look for alternative water disinfection methods or synergistic constituents that are environmentally friendly (Djeussi et al. 2013; Galvao et al. 2012). A very few research papers published (1998-2015) have tested plant extracts, plant proteins and essential oils for their antibacterial potential against surface water isolated bacteria and gray water disinfection. For instance, one study was done on river water isolated bacteria "preparation of Moringa Oleifera flower to treat contaminated water" (Maiara et al. 2011). The researcher used aqueous extract and precipitated protein fraction from Moringa oleifera that showed antibacterial activity against grampositive and gram-negative bacteria derived from the river, lake water. Further, it was concluded that antibacterial activity was due to Moringa oleifera flower preparation could be a potential source of the disinfectant agent to treat contaminated water. In a similar paper published in 2008 entitled "Essential oils for the disinfection of greywater" eight essential oils were tested to disinfect gray water collected from bathroom sinks, bath, and shower it was reported that all essential oils 
showed effective results. The current research project is based on the same principles that determined plant essential oil antibacterial activity (Bauer-Kirby, 1966, F. Karanagh, 1972 and Brantner et al. 1994) against waterborne pathogenic bacteria. This study might add to knowledge to establish the fact that plant essential oils could be another possible alternative solution to inhibit pathogenic and antibiotic resistant bacteria found in water and wastewater. As previous studies have indicated, plant essential oils are well known for their antibacterial properties against a broad range of gram positive and gram negative bacterial pathogens (Edris 2007; Lang and Buchbauer 2012; Teixeira et al. 2013).

\subsection{Plant Essential Oils}

We depend on plants and their components for our fundamental needs such as food, medicine and natural antimicrobial agents (Rai and Kon 2013). Earth has a rich renewable resource of roughly 250,000 higher plant species among which 80,000 species are medicinal (Joy et al. 1998). Since the ancient time, it has been recognized that some plant possesses antimicrobial potential (Finnermore 1926). Over the centuries, mankind has used plants and their parts such as leaves, stems, roots, flowers, seeds, and fruits to cure diseases and relieve physical suffering (Trease and Evans 2009). An essential oil is volatile organic oil which is mostly an aromatic oily liquid derived from different plant parts such as root, stem, leaves, flower, fruit, seeds, twigs, bark, buds, wood, resin and peel through steam distillation (Guenther, 1948; Lawless 2013; Sangwan et al. 2001). Plants are a valuable natural resource that is not only renewable but is also considered environmentally friendly (Chemat et al. 2012). Natural antibacterial components such as plant essential oils, plant extracts, and plant proteins possess antibacterial activity against a broad range of bacteria (Trease and Evans 2009; Maiara et al. 2012; Rai). These plants contain chemical constituents such as essential oils, tannins, polyphenols, terpenoids, phytoalexins, isothiocyanates allicins and anthocyanins (Somaatmadja et al. 1964; Beuchert et al. 1989; Delaquis and Mazza 1995; Lis-Balchin and Deans 1997; Cutter 2000). Nearly 3,000 essential oils are estimated among them with 300 being produced commercially for pharmaceutical purposes as antimicrobial agents (Mendes et al. 2010). Various studies have shown the efficacy of essential oils and their constituents as antibacterial, antiviral, antifungal, insecticidal, herbicidal and antiparasitic potential (Bishop 1995; Carson et al. 1995; Hammer et al. 1999; Burt et al. 2004; Campiglia et al. 2007; Edris 2007; Ayvaz et al. 2010; Stephanie de Rapper et al. 2013; Monzote et al. 2014). 
Further phytochemistry has shown that the antimicrobial potential of plant essential oil is due to compounds such as carvacrol, eugenol, anethole, cinnamaldehyde, cineole, linalool, terpinen-4-ol, and methyl salicylate (Trease and Evans 2009). Essential oils and plant extracts are now gaining acceptance as phytodisinfectants (Yongabi et al. 2011), biopesticides (Mohan et al. 2011), aromatherapy (Ali et al. 2015), pharmaceutical (Edris 2007) and food preservatives (Burt et al. 2004).

\subsubsection{Historical Context}

According to, the medieval forerunner of chemistry also known as Alchemist, the "soul of a plant is its oil, and its spirit is the plant's alcohol or tincture" (Lawless 2013). Historically, fragrant plant oils have been utilized for many years, as incense, perfumes, cosmetics and for their therapeutic and culinary applications. With the advent of human civilization, plant essential oils have been part and parcel of early culture, where their religious and healing roles became inextricably merged. For instance, in the east, springs of juniper are burnt for purification in Tibetan temples, Arabs in middle east use perfumes derived from rose and jasmine in their religious ceremonies. Similarly, in the west, frankincense is used during the Roman Catholic congregation ceremonies (Lawless 2013).

\subsubsection{Ancient History}

The knowledge of the healing power of plant products and their safe usage is as old as the dawn of human civilization. The history of using plant products goes back to the period of early Romans, Greeks, Egyptians, Indians, Arabs, Australians, Africans, and Europeans (Dias et al. 2012). The application of healing power of plants started from the use of poultices and imbibed infusion of thousands of indigenous plants such as hollyhock dating back to the era of Neanderthals (Thomson, W.A.R (ed) 1978; Leroi-Gourhan 1975; Lietava 1992) with actual written evidence documented as far back as the Sumerians (3000-5400 BC) and Akkadians (2270-2083 BC) of ancient Mesopotamia (Costa et al. 1999; Sinclair and Hechtman 2011).

The (1470-1670) era witnessed many publications on herbalism including the "Grete Herbal," and the concept of herbal medicine emerged. For the first time, Paracelsus von Hohenheim (1493-1541) used the term essential oil for a natural product and this term refer to alchemist idea of sublime extractive as "Quinta Essentia" material which acts as an active 
ingredient of pharmacologically important drugs (Guenther 1948; Haagen-Smit. 1961). By the $16^{\text {th }}$ Century, the use of essential oils and their production by distillation became widespread in Europe. In the $17^{\text {th }}$ Century, the preparation of essential oil was well known, and pharmacies stocked 15-20 different oils (Guenther 1948). One of the traditional herbs that later on became a drug by the end of $17^{\text {th }}$ century was Digitalis purpurea L (commonly known as Foxglove) that defined the pathway for modern pharmacology (Goldman 2001). In the $18^{\text {th }}$ Century during colonization of Australia, tea tree was used for a medicinal purpose which was already practiced by the natives of Australia long before. By $19^{\text {th }}-20^{\text {th }}$ Century, use of essential oils medicine gradually become less with the passage of time and was used mostly for flavors and aroma. However, researchers are still focusing their attention on the antimicrobial activity of natural products. Recently researchers have extracted 30000 antimicrobial compounds from 1340 plants (Tajkarimi et al. 2010).

\subsubsection{Current Uses of Essential Oils}

The number of species of plants which are aromatic is estimated to be 17500, distributed across approximately 60 plant families some of which are Asteraceae, Lauraceae, Lamiaceae, Myrtaceae, Pinaceae, Rosaceae, Rutaceae, and Umbelliferae (Bakkali et al. 2008). The essential oils and their components are used successfully as dental canal sealer, fractions are formulated in shampoos, toothpaste, disinfectants, topical ointments, drugs, multivitamins, and cosmetics, perfumery (Manabe et al. 1987), as phytodisinfectants such as Moringa oleifera (Yongabi et al. 2011), as food preservatives to enhance shelf life, (Burt 2004), as pharmaceuticals such as aspirin, quinine, morphine, and eugenol and as biopesticides such as piperidine (Mohan et al. 2011). Due to their relatively safe status "GRAS" Generally recognised as safe (FDA 2016) some essential oils are gaining interest among the consumers based on the fact that they are also considered safe for the environment and mimic the effect of developing resistance to pathogenic bacteria due to diversity of mechanism of action of essential oils their application in packaging material, coated onto polyvinyl surface (Appendini 2002). Highly volatile, essential oils are sometimes lost due to evaporation during the packaging process of finished processed food using microencapsulation technology encapsulating antimicrobial EOs, but they also can be released in products at a controlled rate to deliver effective inhibitory concentrations over extended periods and thereby extend shelf life (Iraj Rasooli 2007). 


\subsubsection{Commercial Production Process of Plant Essential Oils}

The extraction of essential oil is done by steam distillation, cold pressing, or using organic solvents; the oil yield is dependent on environmental conditions and distillation processes. The yield can vary between batches from the same trees and between different sites of their collection (Price 1987). Various techniques for the production of commercial essential oils are used such as the conventional steam distillation method where plant material is placed in a distillation apparatus containing boiling water which produces steam and oil which are recaptured and finally separated out to produce essential oil. An example of steam distillation is seen in the Figure. 3. However, the liquid carbon dioxide or supercritical carbon extraction methods are used when there is less oil present in flowers, and it is performed under low temperature and high pressure. These methods are employed in industrial manufacturing units throughout the world.

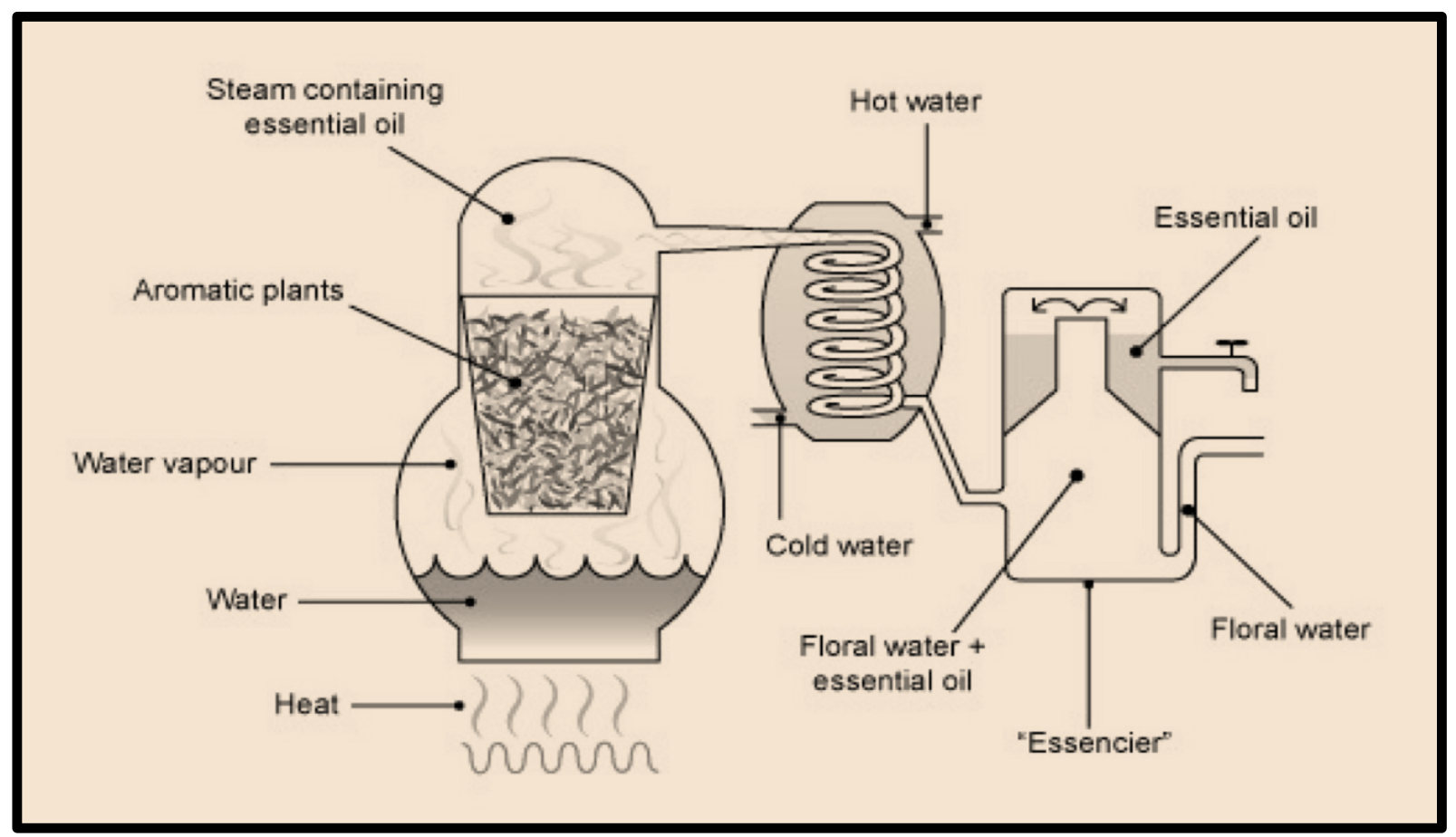

source: (http://www.union-nature.com)

Figure 3. Steam Distillation Manufacturing Process Essential oil.

\subsubsection{Commercial Production of Plant Essential Oil Analysis}

A rough estimate predicts that 3000 plant essential oils are reported in the literature, whereas 300 of them are of commercial importance (Tuley de Silva 1997). In the year 1999, globally the 
business of plant essential oil sales around the world reached $\$ 15$ billion in total among which Europe had $\$ 7$ billion in sales, Japan's sales reached \$2.4, Asia's sales reached \$2.7, and North America's sales reach $\$ 3$ billion. Commercially an approximate production of 40,000 to 60,000 tons per annum has been reported worldwide with an ever increasing trend regarding consumption (Djlani and Dicko. 2012). An overview of world and Canadian exports of plant essential oil depicts its ever growing need within the global market (Fig 4, Table 2.3).

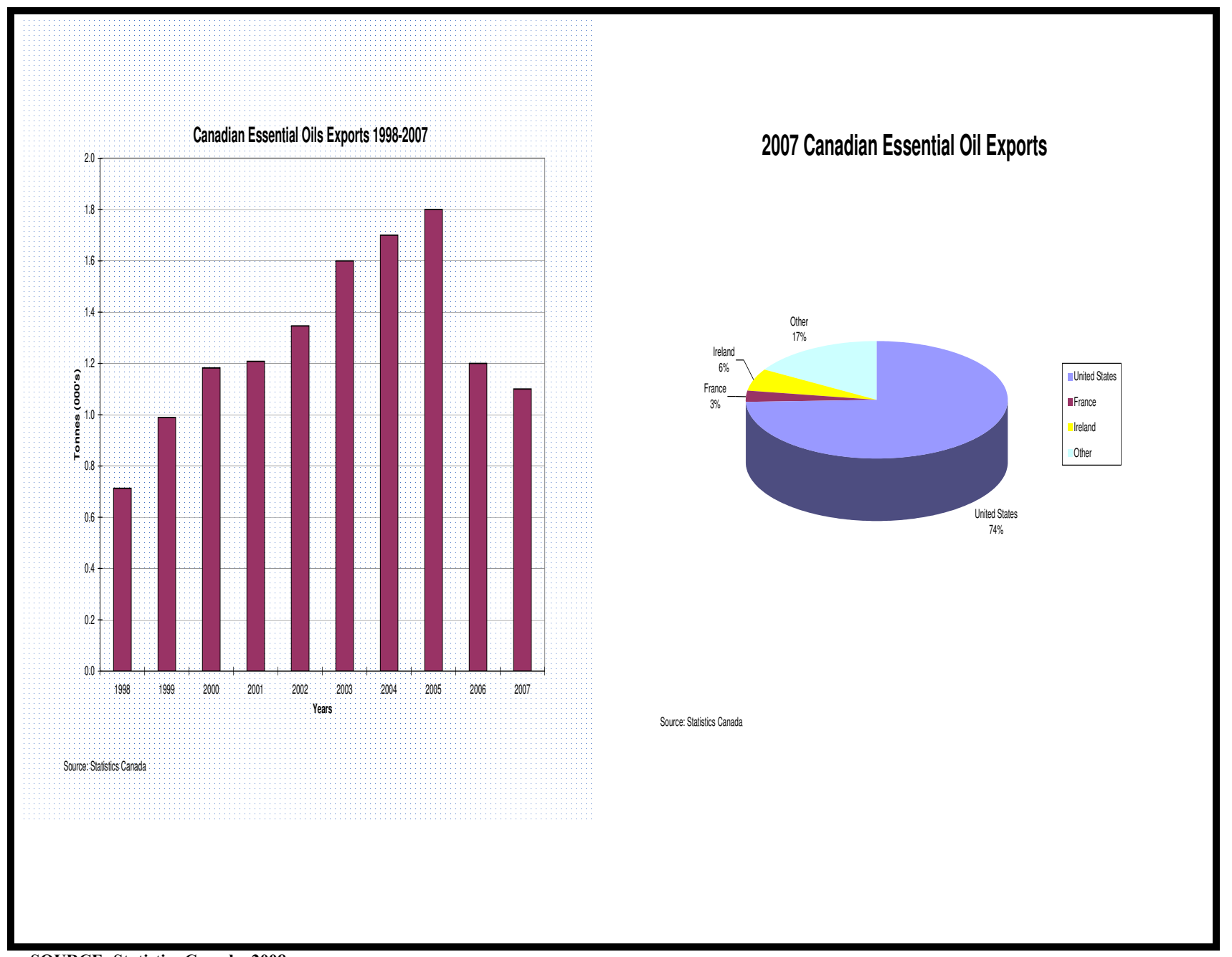

SOURCE: Statistics Canada, 2008

Figure 4 Canadian Essential Oil Exports (1998-2007) 
Table 2.3. Production Analysis of Important Essential Oils (2008)

\begin{tabular}{|c|c|c|}
\hline Essential Oil & $\begin{array}{c}\text { Production } \\
\text { (Metric Tons) }\end{array}$ & Countries \\
\hline Orange oils & 51000 & USA, Brazil, Argentina \\
\hline Corn mint oil & 32000 & India, China, Argentina \\
\hline Lemon oils & 9200 & Argentina, Italy, Spain \\
\hline Eucalyptus oils & 4000 & China, India, Australia, South \\
\hline & & Africa \\
\hline Peppermint oil & 3300 & India, USA, China \\
\hline Clove leaf oil & 1800 & Indonesia, Madagascar \\
\hline Citronella oil & 1800 & China, Sri Lanka \\
\hline Spearmint oils & 1800 & USA, China \\
\hline Cedar wood oils & 1650 & USA, China \\
\hline Litsea cubeba oil & 1200 & China \\
\hline Patchouli oil & 1200 & Indonesia, India \\
\hline Lavandin oil & 1100 & France \\
\hline Corymbia citriodora oil & 1000 & China, Brazil, India, Vietnam \\
\hline Oregano oil & $15-20$ & Turkey \\
\hline Cinnamon oil & 90 & Sri Lanka \\
\hline Clove oil & 2000 & Indonesia, Madagascar, Sri Lanka \\
\hline Tea tree & $2-20$ & Australia \\
\hline Fennel oil & 0.35 & Turkey \\
\hline Wintergreen & $50-80$ & China \\
\hline
\end{tabular}

Source: Lawrence 2009; Trease and Evans 2009.

\subsubsection{Composition of Plant Essential Oil}

Antibacterial activity of plant essential oils can be attributed to the chemical constituents and functional groups present in plant essential oils, the proportions in which they are present, and the interactions between them (Dorman and Deans 2000). higher inhibition activity of clove, cinnamon, oregano, essential oil are due to the main constituents, cinnamaldehyde, eugenol, 
thymol, and carvacrol, against Staphylococcus aureus and Pseudomonas aeruginosa (Lambert et al. 2001). It has been observed that the combination of thymol and carvacrol exhibited higher antibacterial activity than either compound alone and further that the inhibitory effect of oregano is mainly due to the additive antibacterial action of these two compounds (Delaquis et al. 1995). The detailed compositional analysis achieved by gas chromatography and mass spectrophotometry of essential oils have shown that phenolic compounds are chiefly responsible for antimicrobial activity (Cosentino et al. 1999). A chemical structural formula of the main antibacterial components of plant essential oils is seen in Figure 5. As reported by various researchers from (1999 to 2014) cinnamon essential oil possesses $80 \%$ cinnamaldehyde (Mith et al. 2014), clove essential oil possess $85 \%$ to $95 \%$ eugenol (Moreira et al. 2005), oregano essential oil possesses 46\% cineole and $26.1 \%$ linalool (Ultee and Smid 2001), fennel essential oil possesses anethol $55 \%$ to $75 \%$ anethol (Hammer et al. 1999), tea tree essential oil possess $40.1 \%$ terpine- 4 -ol (Hammer et al. 1999) and winter green possesses methyl salicylate 95\% methyl salicylate (Hammer et al. 1999).

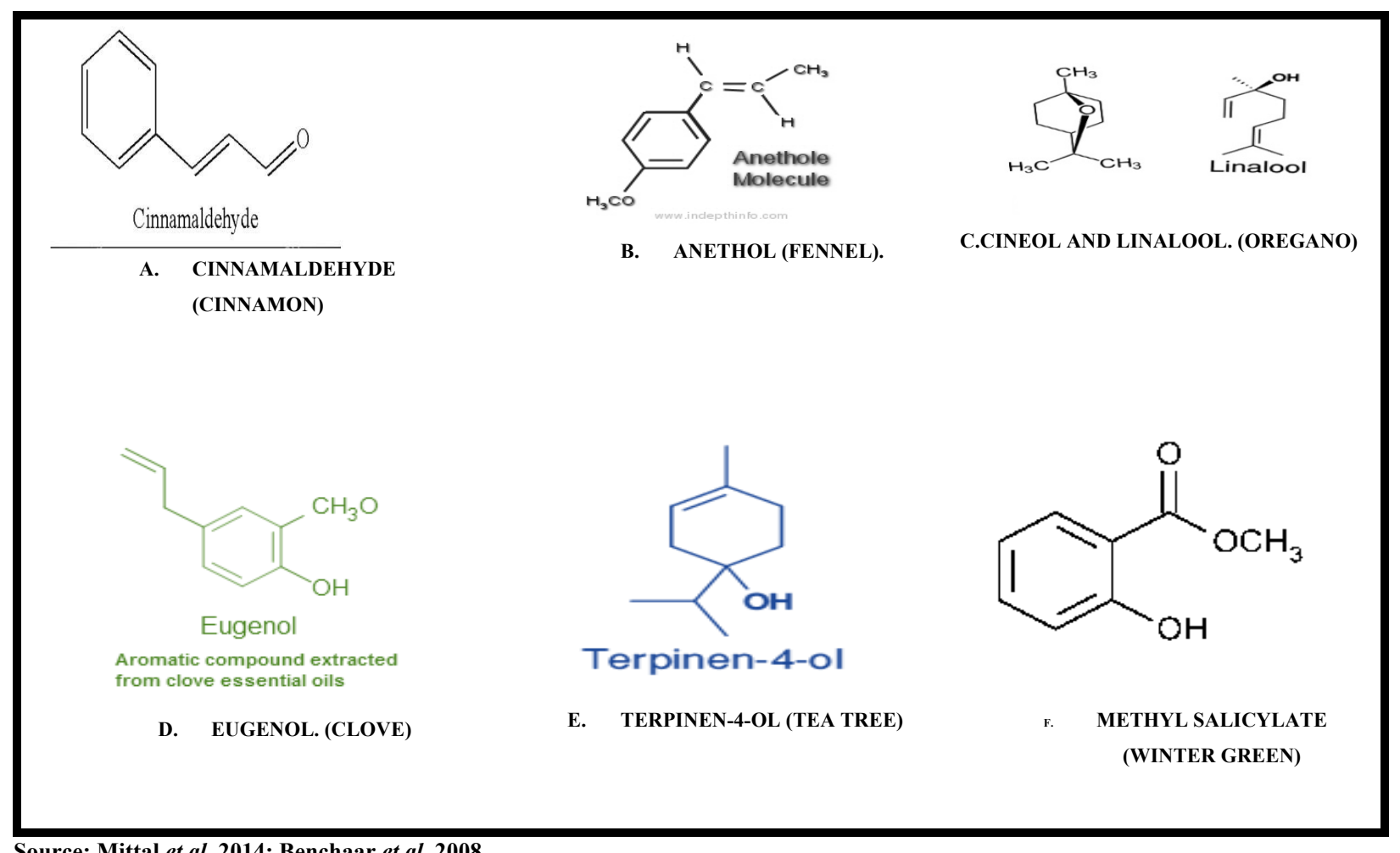

Source: Mittal et al. 2014; Benchaar et al. 2008.

Figure 5. Structural Formula of Essential Oils Constituents of Clove, Cinnamon, Oregano, Fennel, Tea tree, Wintergreen. 
Table 2.4. Essential oil Distribution, Antibacterial Components, Literature value.

\begin{tabular}{|c|c|c|c|c|c|c|}
\hline Essential oil & Plant Species & $\begin{array}{l}\text { Antibact } \\
\text { compone }\end{array}$ & $\begin{array}{l}\text { erial } \\
\text { nts }\end{array}$ & & $\begin{array}{l}\text { Part of } \\
\text { Plant }\end{array}$ & Origin \\
\hline Cinnamon & $\begin{array}{l}\text { Cinnamomum } \\
\text { zeylanicum }\end{array}$ & $\begin{array}{l}\text { Cinnamald } \\
65 \%-80 \%\end{array}$ & hyde & & $\begin{array}{l}\text { Bark of } \\
\text { tree }\end{array}$ & Sri Lanka \\
\hline Clove & $\begin{array}{l}\text { Syzygium } \\
\text { aromaticum }\end{array}$ & $\begin{array}{l}\text { Eugenol } \\
75 \%-85 \%\end{array}$ & & & Bud & Madagascar \\
\hline Oregano & Origanum vulgare & $\begin{array}{l}\text { Carvacrol } \\
80 \%\end{array}$ & $\begin{array}{l}\text { Cineole } \\
46 \%\end{array}$ & $\begin{array}{l}\text { Linalool } \\
26.1 \%\end{array}$ & Leaves & $\begin{array}{c}\text { Mediterranean, } \\
\text { Europe }\end{array}$ \\
\hline Tea tree & $\begin{array}{l}\text { Melaleuca } \\
\text { alternifolia }\end{array}$ & $\begin{array}{l}\text { Terpnen-4- } \\
40.1 \%\end{array}$ & & & Leaves & Australia \\
\hline Fennel & $\begin{array}{l}\text { Foeniculum } \\
\text { vulgare }\end{array}$ & $\begin{array}{l}\text { Anethole } \\
55-75 \%\end{array}$ & & & Seed & Spain \\
\hline Wintergreen & $\begin{array}{l}\text { Gaultheria } \\
\text { procumbens }\end{array}$ & $\begin{array}{l}\text { Methyl Sal } \\
95 \%\end{array}$ & cylate & & Berries & North America \\
\hline
\end{tabular}

Source: Hammer et al. 1999, Ultee and Smid, 2001, Mith et al. 2014, Moreira et al. 2005

This study examines the antibacterial potential of six plant essential oils by employing KirbyBauer disc diffuaion assay against bacterial pure cultures. The three most effective essential oils were then selected for qualitative and quantitative analysis of bacterial communities from a wastewater treatment plant process.

\subsection{Antibacterial Mode of Action}

Studies show that antibacterial activity of essential oil is due to different modes of action of essential oil on bacterial cell such as cell wall and membrane disturbance, ATP production imbalance, protein synthesis imbalance, $\mathrm{pH}$ disturbance, intracytoplasmic changes, bacterial DNA mutation, anti-quorum sensing activity (Oussalah et al. 2007; Becerril et al. 2012; Burt et al. 2004; Bouhdid et al. 2009; Turgis et al. 2009; Khan et al. 2009; Brackman et al. 2011). Studies show the antibacterial activity of essential oils is linked to hydrophobicity resulting in greater cell permeability and ultimately leakage of cell constituents (Ultee et al. 2000; Lambert et al. 2001; Caillet et al. 2005). Scanning electron microscopy (SEM) observation of food borne bacteria E.coli 0157:H7 and Salmonella enterica showed the presence of white spots and holes on the cell wall, distorted and unfinished cell shape when exposed to orange, mustard, and spanish oregano 
essential oil (Gaunt et al. 2005; Turgis et al. 2009). Studies reported the action of essential oil components such as carvacrol and p-cymene triggered the production of heat shock protein (HSP) in E.coli 0157:H7 (Burt et al. 2003). Some studies also reported intracellular ATP loss through membrane disturbance (Oussalah et al. 2007; Turgis et al. 2009) in bacterial strains such as E.coli 0157:H7, Listeria monocytogenes, Staphylococcus aureus and Salmonella enterica. Bacteria showed a decrease in intracellular ATP when exposed to oil of mustard, oil of oregano and carvacrol at their MIC concentration (Ultee et al. 2000; Caillet et al. 2005; Turgis et al. 2009). Similarly, a decrease in $\mathrm{pH}$ has been reported in E.coli 0157:H7, Salmonella enterica, Listeria monocytogenes, Staphylococcus aureus and Pseudomonas aeruginosa when exposed to oil of oregano, oil of cinnamon, oil of savory and oil of mustard (Ultee et al. 2000; Oussalah et al. 2007; Turgis et al. 2009).

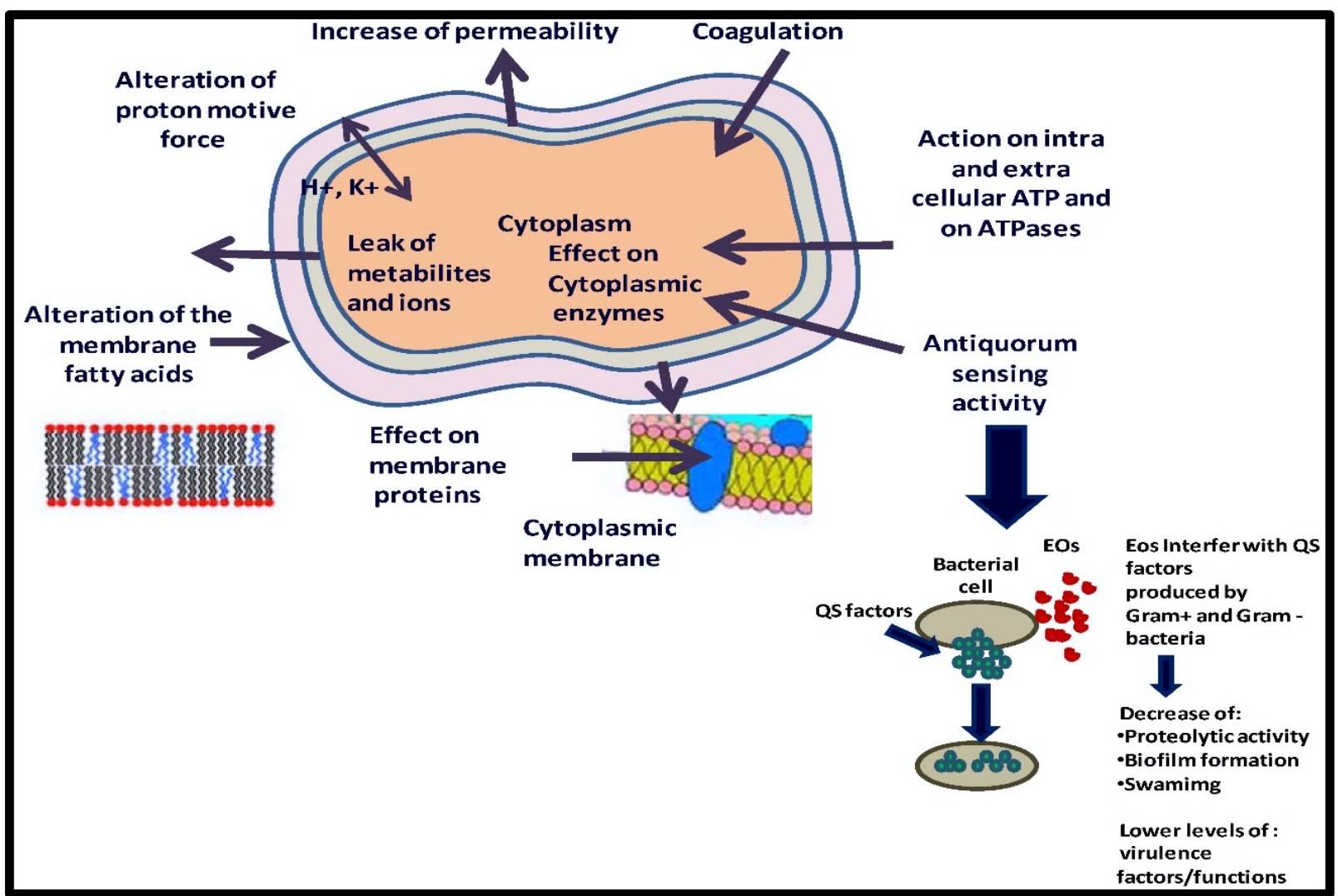

Source: Nazzaro et al. 2013.

Figure 6. Modes of Action of Plant Essential Oils on the Bacterial Cell.

Some studies show anti-quorum sensing activity of cinnamon, clove, geranium, lavender and rosemary (Khan et al. 2009; Brackman et al. 2011). 


\subsubsection{Antibacterial Studies}

Based on a literature review of articles published (1994-2016 see reference below), six essential oils were selected for study based on their antibacterial properties and their minimal toxicity. The six essential oils were oil of clove (Syzygium aromaticum L.), oil of cinnamon (Cinnamomum zeylanicum. (Nees \& T.Nees, J.Presl), oil of oregano (Origanum vulgare L.), oil of tea tree (Melaleuca alternifolia (Maiden \& Betche), Cheel), oil of fennel (Foeniculum vulgare Mill.), and oil of wintergreen (Gaultheria procumbens. L.). Previous studies have shown antibacterial properties of the above mentioned essential oils against a wide array of bacteria.

\subsubsection{Clove Essential Oil}

Extraction of clove oil is done from the flower buds of Syzygium aromaticum L., which belong to the family Myrtaceae, a tree 10-20m high that is indigenous to melaleuca or clove island; oil of clove is a colorless, pale yellow liquid. The major chemical constituents are eugenol (84-95 \%), acetyl eugenol (3\%), carvacrol and cinnamaldehyde (Trease and Evans, 1989). Eugenol is utilized widely in perfume and flavoring industries. The FDA considers eugenol as Generally Recognised As Safe ("GRAS”). A literature review of eight relevant articles published between 1998-2014 used clove essential oil against a wide array of bacteria isolated from sources such as food, food spoilage, soil, and hospital. In antibacterial studies, Kirby-Bauer disc diffusion method has been employed to test bacterial sensitivity to clove essential oil the results showed significant antibacterial activity against bacterial strains such as E.coli, E.coli: 0157, Staphylococcus aureus, Pseudomonas aeruginosa, Bacillus subtilis, Proteus vulgaris, Salmonella enteritis, Campylobacter jejuni (Smith-Palmer et al. 1998; Hammer et al. 1999; Burt et al. 2003; Dorman and Deans 2003; Carson et al. 2006; Roller et al. 2009; Rather et al. 2012). Furthermore, clove essential oil have reduce the bacterial population completely at or below MIC value of $5000 \mathrm{mg} / \mathrm{l}$ level for Escherichia coli, Staphylococcus aureus, Bacillus cereus, Yersinia enterocolitica (Siddiqua et al. 2014). In another study, de Rapper et al. (2013) reported MIC against Staphylococcus aureus and Pseudomonas aeruginosa of $1.5 \mathrm{mg} / \mathrm{ml}$. Similarly, (Burt et al. 2003) reported a MIC value of $0.4-2.5 \mathrm{ul} / \mathrm{ml}$ each based on microdilution assay for clove essential oil against food isolated pathogens such as E.coli and Staphylococcus aureus. It was also reported that MICs against Klebsiella pneumoniae and E.coli were $>6.4 \mathrm{mg} / \mathrm{ml}$ and $>1.6 \mathrm{mg} / \mathrm{ml}$ 
respectively (Prabuseenvasan et al. 2006). Moreira et al. (2005) reported a MIC value for clove essential oil against E.coli ATCC 25158 of $0.25 \mathrm{ml} / 100 \mathrm{ml}$.

\subsubsection{Cinnamon Essential Oil}

Extraction of Cinnamon oil is from the bark of the shoots grown on the cut stock of Cinnamon cassia Blume. It is native to Sri Lanka and cultivated in Ceylon, Madagascar, Jamaica, and Brazil. The major chemical constituents are cinnamic aldehyde and 4-10\% eugenol (Trease and Evans 1989). FDA considers cinnamon essential oil as Substance Generally Recognised As Safe (“GRAS"). A literature review of eight relevant articles published between 1998-2014 used cinnamon essential oil against a broad range of bacterial strains isolated from sources such as food, soil, and hospital. Studies conducted on essential oil of cinnamon have shown significant antibacterial activity during preliminary screening against bacteria such as Brochothrix thermosphacta, E.coli, E.coli: 0157, Listeria monocytogenes, Salmonella typhimurium, Staphylococcus aureus, Pseudomonas flourescens, Pseudomonas aeruginosa, Bacillus subtilis, Proteus vulgaris, Salmonella enteritis, Campylobacter jejuni (Smith-Palmer et al. 2002; Prabuseenivasan et al. 2006; Oussalah et al. 2007 ; Dobre et al. 2011; Becerril et al. 2012; Akhtar et al. 2014; Yap et al. 2014 ; Raut et al. 2014; Mith et al. 2014). Using the Kirby-Bauer disc diffusion method (Mith et al. 2014) showed the antibacterial activity of cinnamon essential oil against food-borne, food spoilage bacteria such as Listeria monocytogenes, Salmonella typhimurium, E.coli: 0157, Brochothrix thermosphacta, Pseudomonas fluorescens, E.coli, Staphylococcus aureus. Furthermore, the cinnamon essential oil showed significant inhibition with a MIC value of $0.125 \mathrm{ul} / \mathrm{ml}$, and an MBC (Minimum Bactericidal Concentration) value of $0.25 \mathrm{ul} / \mathrm{ml}$ against all five bacteria tested except Pseudomonas fluorescens that remained resistant against cinnamon at $\mathrm{MIC} / \mathrm{MBC}$ value $1 \mathrm{ul} / \mathrm{ml}$. According to another paper, the MIC of cinnamon essential oil against Klebsiella pneumoniae and E.coli was $3.2 \mathrm{mg} / \mathrm{ml}$, and $>1.6 \mathrm{mg} / \mathrm{ml}$ respectively (Prabuseenvasan et al. 2006). Similarly, another paper has reported a MIC value of $5 \mathrm{mg} / \mathrm{ml}$ of cinnamon essential oil against E.coli with broth microdilution assay (Silveria et al. 2012).

\subsubsection{Oregano Essential Oil}

Oregano oil extracted from the leaves of Origanum vulgare L., which belong to the family Lamiaceae, is a perennial herb that grows from $8-20 \mathrm{~cm}$ tall having opposite leaves $1-4 \mathrm{~cm}$ long. 
Oregano oil chemically consists of cineole $46 \%$ and linalool 26.1\% (Trease and Evans 1989). A literature review done on relevant articles published between 2000-2012 used oregano essential oil against a wide array of bacteria isolated from sources such as food, food spoilage, soil, and hospital. Studies conducted on essential oil of oregano have shown significant antibacterial activity during preliminary screening by employing disc diffusion method of oregano essential oil against bacteria such as Acinetobacter calcoacetica, Aeromonas hydrophila, Alcaligenes faecalis, Bacillus subtilis, Beneckea natriegens, Brevibacterium linens, Brocothrix thermosphacta, Citrobacter freundii, Clostridium sporogenes, Enterococcus faecalis, Enterobacter aerogenes, Erwinia carotovora, Escherichia coli, Flavobacterium suaveolens, Klebsiella pneumonia, Lactobacillus plantarum, Leuconostoc cremoris, Micrococcus luteus, Proteus vulgaris, Pseudomonas aeruginosa, Salmonella pullorum, Serratia marcescens, Staphylococcus aureus and Yersinia enterocolitica, Enterobacter cloacae, E.coli ATCC25158, E.coli ATCC32922, E.coli CI, E.coli CII, (Dorman 2000; Moreira et al. 2005; Silviera et al. 2012). Furthermore, a MIC assay of oregano essential oil against Aeromonas hydrophilia showed MIC value of $2.5 \mathrm{ul} / \mathrm{ml}$ when the broth microdilution assay was employed (Azeredo et al. 2011). Similarly, another paper showed a MIC value of $0.5 \mathrm{ug} / \mathrm{ml}$ against Enterobacter cloacae by employing the broth microdilution assay (Sokovic et al. 2010). It was also reported in the literature that oregano essential oil possesses a MIC value of $1.8 \mathrm{ml} / 100 \mathrm{ml}$ against E.coli based on a broth microdilution assay (Moreira et al. 2005).

\subsubsection{Tea Tree Essential Oil}

Tea tree oil is derived from leaves of Melaleuca alternifolia which belong to the family Myrtaceae, native to Australia, is a tree or tall shrub about $7 \mathrm{~m}$ tall. The major chemical constituents of tea tree oil are terpinin 4-ol 40\% (Trease and Evans, 1989). A literature review done on a relevant articles published between 1997-2005 have demostrated tea tree essential oil against few bacteria isolated from sources such as food, food spoilage, soil, and hospital. Studies conducted on essential oil of tea tree have shown least antibacterial activity during preliminary screening by employing disc diffusion method against bacteria such as Escherichia coli, Pseudomonas aeruginosa, and Staphylococcus aureus, E.coli ATCC25158, E.coli ATCC32922, E.coli CI, E.coli CII, (Hili 1997; Moreira et al. 2005). 


\subsubsection{Fennel Essential Oil}

Sweet fennel oil is extracted from seeds of Foeniculum vulgare L. subsp. vulgare, var. dulce, ("Umbelliferae") the fruit resembles a bitter variety but has a sweet taste and low volatile content. Cultivated in many parts of Europe and imported from India, China and Pakistan (Trease and Evans 1989). A literature review done on a relevant article published in 2006 used fennel essential oil against few bacteria isolated from sources such as food, food spoilage, soil, and hospital. Studies conducted on essential oil of fennel have shown some antibacterial activity during preliminary screening by employing disc diffusion method against bacteria such as Bacillus subtilis, Bacillus cereus, Escherichia coli, Pseudomonas sp and Staphylococcus aureus (Helal et al. 2006).

\subsubsection{Winter Green Essential Oil}

Wintergreen oil is extracted from leaves of Gaultheria procumbens which belong to the family Ericaceae. It is a small, low-growing shrub, typically reaching 10-15 cm tall. The leaves are elliptical to ovate $2-5 \mathrm{~cm}$ long and 1-2 $\mathrm{cm}$ broad. The major chemical constituent of the oil of wintergreen is methyl salicylate. A literature review done on a relevant article published in 2006 used wintergreen essential oil against few bacteria isolated from sources such as food, food spoilage, soil, and hospital. Studies conducted on essential oil of wintergreen have shown some antibacterial activity during preliminary screening by employing disc diffusion method against bacteria such as Proteus vulgaris, Escherichia coli, Pseudomonas aeruginosa, Staphylococcus cerevisiae, Bacillus subtilis. There was no activity recorded against Klebsiella pneumonia (Prabuseenivasan et al. 2006). 


\section{CHAPTER THREE}

\section{MATERIAL AND METHODS}

\subsection{Source of Experimental Bacterial Cultures}

Both wild-type and wastewater isolated bacterial cultures were previously isolated from the wastewater activated sludge treatment process by our lab and identified.

\subsubsection{Bacterial Pure Cultures}

The bacterial pure cultures listed in Table 3.1 were utilized for preliminary screening testing. Frozen stocks of all the strains, made with $40 \%$ glycerol and $60 \%$ of a $5 \% \mathrm{w} / \mathrm{v}$ trisodium citrate solution in water, were maintained at $-80^{\circ} \mathrm{C} \pm 1{ }^{\circ} \mathrm{C}$ and routinely subcultured onto Nutrient Agar (Difco Laboratories, MI, USA) plates. The cultures were stored at $4^{\circ} \mathrm{C}$ and sub-cultured every week to maintain viability and avoid contamination.

\subsubsection{Wastewater mixture sample collection.}

The wastewater samples were taken from the activated sludge tanks (AT-2, AT-4, AT-6, AT-8) the digestors, (DIG-1 DIG-2) and the returned sludge (RS). WWTP bacterial aeration tank samples were obtained from the Humber Wastewater Treatment Plant and used to test the efficacy of the oils against a mixed culture.

\subsection{Preparation of Inoculum}

Broth suspension of the wild type pure bacterial cultures and wastewater isolated bacteria were prepared by inoculating $3 \mathrm{ml}$ of Tryptic Soy Broth (Scott Laboratories Inc., CA, USA) with a single colony from the respective R2A Agar plate culture. and vortexed; colonies were added until the suspension matched a 0.5 McFarland standard. 
Table 3.1. Inventory of wild type and wastewater isolated bacterial cultures.

\begin{tabular}{|c|c|c|}
\hline Name of Bacteria & Lab Frozen Stock No & $\begin{array}{l}\text { Source of strain } \\
\text { (Lab Isolated) }\end{array}$ \\
\hline Acinetobacter baumannii & 27 & Wild type \\
\hline Acinetobacter baumannii & $12 \mathrm{~K}$ & WWTP \\
\hline Acinetobacter bouretii & $10 \mathrm{~A}$ & WWTP \\
\hline Aeromonas hydrophila & $7 \mathrm{~A}$ & WWTP \\
\hline E. coli: $D H 5 \infty$ & 17 & Wild type \\
\hline E. coli: AD202 & 36 & Wild type \\
\hline E. coli: $D H 5 \infty$ & 9 & Wild type \\
\hline E. coli & & WWTP \\
\hline Enterobacter cloacae & $12 \mathrm{E}$ & WWTP \\
\hline Flavobacterium branchiophilum & $8 \mathrm{I}$ & WWTP \\
\hline Klebsiella pneumoniae & $11 \mathrm{~A}$ & WWTP \\
\hline Pseudomonas fluorescens & 8 & Wild type \\
\hline Pseudomonas poae & 26 & Wild type \\
\hline Pseudomonas putida & BBC- 443 & Wild type \\
\hline Pseudomonas staurtii & $14 \mathrm{D}$ & WWTP \\
\hline Serratia fonticola & $4 \mathrm{~B}$ & WWTP \\
\hline Staphylococcus aureus & 16 & Wild type \\
\hline Staphylococcus muscae & $15 \mathrm{D}$ & WWTP \\
\hline Stenotrophomonas maltophilia & 13 & Wild type \\
\hline Stenotrophomonas maltophilia & 33 & WWTP \\
\hline
\end{tabular}

3 A wild type is the original strain of an organism which has not undergone any form of mutation genetically or phenotypically 


\subsection{Selection of Essential Oil}

The commercial essential oils such as clove, cinnamon, oregano, fennel, teatree, and wintergreen manufactured by Now essential oils were purchased from Noah Natural Food Canada. These essential oils were claimed $100 \%$ pure extracted through steam distillation process. For broth tube, macro-dilution MIC assay each essential oils were dissolved in 5\% Tween, a stabilizing and dispersing agent, as required. All essential oils used in this experiment are listed in Table. 3.2

Table 3.2. Plant Essential oils Inventory with Scientific Name, Common Name, Specific Gravity, Concentration and Color.

\begin{tabular}{|c|c|c|c|c|}
\hline Scientific Name & $\begin{array}{c}\text { Common } \\
\text { Name }\end{array}$ & $\begin{array}{c}\text { Specific } \\
\text { gravity }\end{array}$ & $\begin{array}{c}{ }^{4} \text { Concentration } \\
\text { in } \mathrm{mg} / \mathrm{ml} \text { of } \\
50 \mathrm{uL} \text { of } \mathrm{E} . \mathrm{O} \\
\text { taken }\end{array}$ & Color \\
\hline Cinnamoтит cassia (Nees \& T.Nees) J.Presl & Cinnamon & 1.03 & $51.5 \mathrm{mg} / \mathrm{ml}$ & Pale yellow \\
\hline Foeniculum vulgare Mill. & Fennel & 0.96 & $48 \mathrm{mg} / \mathrm{ml}$ & Pale yellow \\
\hline Gaultheria procumbens $\mathrm{L}$. & Winter Green & 1.18 & $59 \mathrm{mg} / \mathrm{ml}$ & Pinkish yellow \\
\hline Origanum vulgare $\mathrm{L}$. & Oregano & 0.94 & $47 \mathrm{mg} / \mathrm{ml}$ & Pale yellow \\
\hline Melaleuca alternifolia (Maiden \& Betche) Cheel & Tea Tree Oil & 0.89 & $44.5 \mathrm{mg} / \mathrm{ml}$ & Colorless \\
\hline Syzygium aromaticum (L.) Merrill \& Perry. & Clove & 1.04 & $52 \mathrm{mg} / \mathrm{ml}$ & Colorless \\
\hline
\end{tabular}

Source: Hili 1997; Hammer et al. 1999; Dorman. 2000; Helal et al. 2006; Prabuseenivasan et al. 2006; Mith et al. 2014

\subsection{Antibacterial Assay}

The antibacterial assay was divided into a two-tiered testing process.

1. The qualitative analysis involved preliminary screening of plant essential oils against bacterial pure cultures using the Kirby-Bauer disc diffusion method.

2. The quantitative analysis which included the determination of MIC by employing broth tube macro-dilution assay.

\subsubsection{Kirby-Bauer disc diffusion Assay}

The Kirby-Bauer disc diffusion method was adopted from National Committee on Clinical Laboratory Standards for preliminary screening of essential oils which is principally modified from testing of antibiotics (Hammer et al. 1999; NCCLS 2014). Testing was done with cultures that had been grown in a Tryptic Soy Broth (TSB) suspension standardized to a 0.5 McFarland standard representing approximately $1 \times 10^{6} \mathrm{CFU}$.

\footnotetext{
${ }^{4}$ Assuming Each E.O's are100 \% pure as claimed by manufacturer. The concentration is calculated based on Specific Gravity of each E.O's multiplied by the volume used for each Assay.
} 


\subsubsection{Preparation of Discs}

To complete the Kirby-Bauer disc diffusion assay as suggested by National Committee on Clinical Laboratory Standards., the necessary antibacterial susceptibility discs containing the essential oils were inoculated with $50 \mathrm{uL}$ of the essential oil and left to diffuse into the disc for 2 hours.

\subsubsection{Experimental Design}

\subsubsection{Preliminary Screening of Essential Oils}

Each plant essential oil was tested for antibacterial activity (Fig. 7A) against all the selected wild type bacterial cultures and wastewater isolated bacteria (Table 3.1). A bacterial suspension was prepared by inoculating $3 \mathrm{ml}$ of TSB with pure colonies, and vortexed; colonies were added until the suspension matched a $0.5 \mathrm{McFarland}$ standard. A sterile cotton swab was then dipped into the bacterial suspension and swabbed onto the R2A agar plate. Prepared filter discs (13 $\mathrm{mm}$ or $6 \mathrm{~mm})$ immersed with the essential oils, were placed onto the surface of the agar. The Petri plates were then incubated in an upright position at $37^{\circ} \mathrm{C}$ for 72 hours. Petri plates were sealed with paraffin or plastic tape to reduce evaporation of essential oil component.

The experiments were carried out in triplicate for each essential oil against each of the wild type bacterial cultures. Simultaneously controls were tested by using $50 \mu$ of vegetable oil and $5 \%$ acetone to compare the efficacy of antibacterial constituents found in each essential oil. Testing of antibacterial activity of 5\% acetone or vegetable oil such as $5 \%$ olive oil are used as diluent in some essential oils. The susceptibility of bacteria to the inhibitory effects of the selected essential oils was assessed based on the Kirby-Bauer disc diffusion assay (Hammer et al. 1999; NCCLS 2014). All the steps involved in the antibacterial assay were performed in sterilized/ aseptic condition. 


\section{Experimental Design}

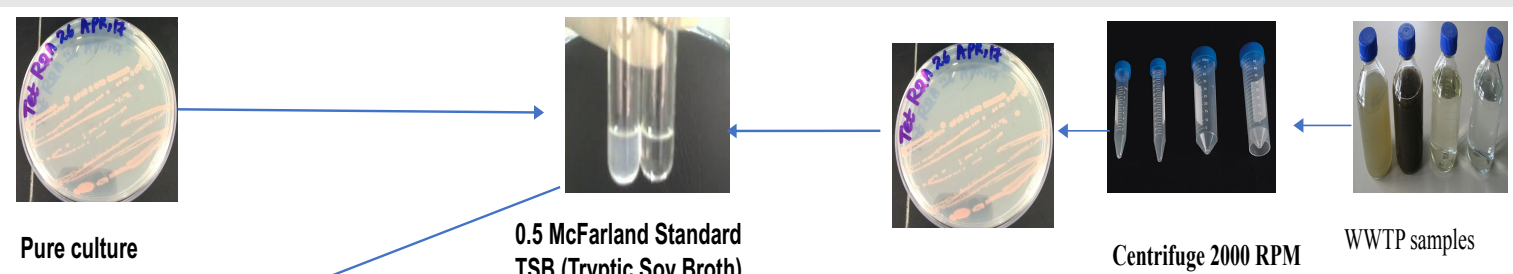

Sterile swab used to spread the suspension on to R2A Plate

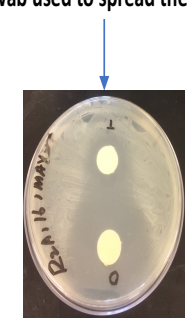

A

Kirby- Bauer disc diffusion Assay

- Kirby and Bauer. 1966.

- NCCLS. 2014. TSB (Tryptic Soy Broth)

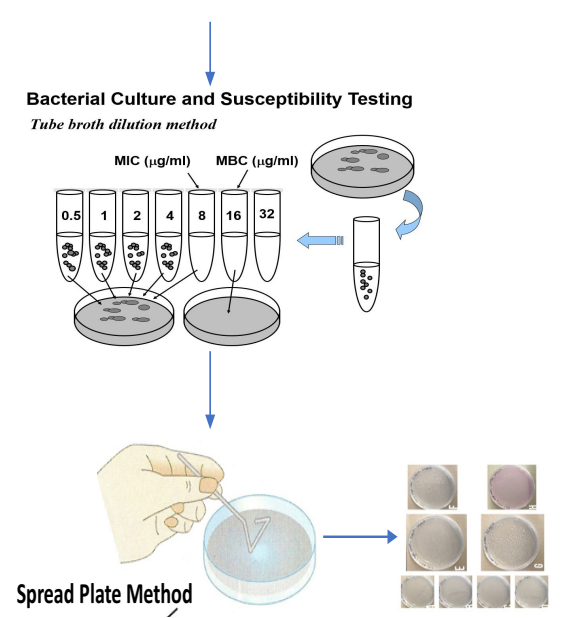

B Broth-tube Macro-dilution MIC Assay
Centrifuge 2000 RPM

WWTP samples

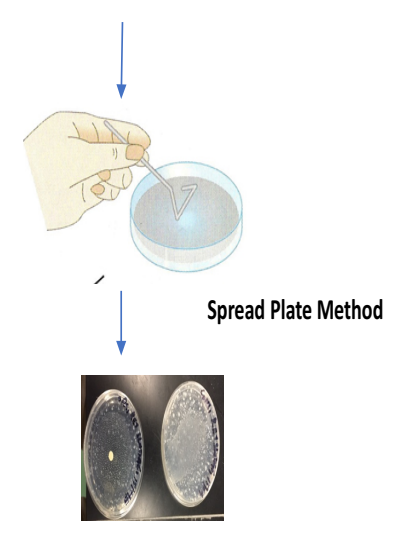

Kirby-Bauer disc diffusion Assay

Figure 7. Experimental Design (A) Kirby-Bauer Disc Diffusion Assay (B) Minimum Inhibitory Concentration (C) Kirby-Bauer Disc diffusion assay for wastewater mix bacterial cultures. 


\subsubsection{Zone of Inhibition}

The zone of inhibition was determined by measuring the diameter of the zone in $\mathrm{mm}$ minus the diameter of the disc. The bacterial sensitivity and diameter of the zone of inhibition was determined with slight modification to interpret the results. The zones of inhibition produced by the essential oil were recorded by using a scale (Fig. 8).

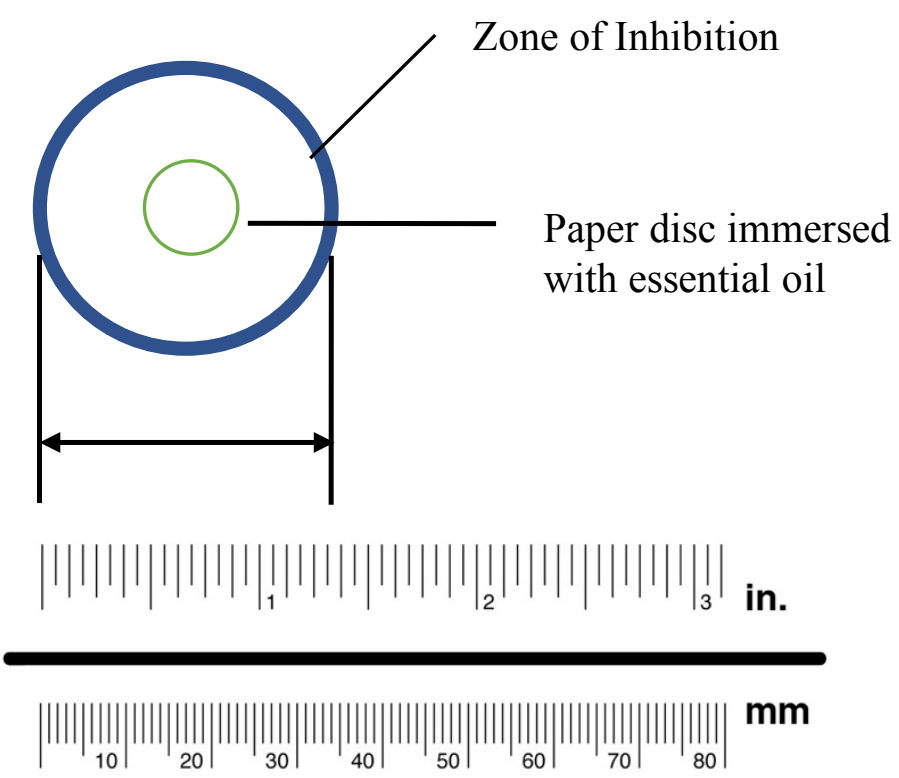

Figure 8. Zone of Inhibition Measurement 
Table 3.3. Bacterial Sensitivity and Diameter of Zone of Inhibition (13 mm*; 6 mm**)

\begin{tabular}{|c|c|}
\hline Sensitivity & Zone of inhibition in $\mathrm{mm}$ \\
\hline (-) Not Sensitive. & $\begin{array}{l}\text { - Zone of inhibition less than or equal to } 14 \mathrm{~mm}^{*} \\
\text { - Zone of inhibition less than or equal to } 7 \mathrm{~mm}^{* *}\end{array}$ \\
\hline$(+)$ Intermediate & $\begin{array}{l}\text { - Zone of inhibition of diameter } 15 \mathrm{~mm}-17 \mathrm{~mm}^{*} \\
\text { - Zone of inhibition of diameter } 8 \mathrm{~mm}-10 \mathrm{~mm}^{* *}\end{array}$ \\
\hline$(++)$ Sensitive. & $\begin{array}{l}\text { - Zone of inhibition of diameter } 19 \mathrm{~mm}-23 \mathrm{~mm} * \\
\text { - Zone of inhibition of diameter } 12 \mathrm{~mm}-14 \mathrm{~mm} * *\end{array}$ \\
\hline$(+++)$ Very Sensitive & $\begin{array}{l}\text { - Zone of inhibition of diameter greater than } 24 \mathrm{~mm}^{*} \\
\text { - Zone of inhibition of diameter greater than } 15 \mathrm{~mm}^{* *}\end{array}$ \\
\hline
\end{tabular}

Source: Moriera et al. 2005

* measurement used with larger $13 \mathrm{~mm}$ discs

** measurement used with smaller $6 \mathrm{~mm}$ discs

\subsection{Determination of MIC (Minimum Inhibitory Concentration)}

Minimum inhibitory concentration (MIC) is the lowest concentration of a compound required to inhibit visible growth of bacteria after 72 hrs incubation time. Based on the results obtained from the preliminary screening assay of the six essential oils, three oils (clove, cinnamon, and oregano) were subjected to quantitative analysis. The MIC assay was carried out by employing the broth tube macro-dilution method with modification (Ericsson and Sherris, 1971; Wiegand et al. 2008). Wastewater isolated bacterial cultures (Table 3.1) were tested against clove, cinnamon and oregano oils (Table 3.2) to determine the MIC (Minimum Inhibitory Concentration) of each essential oil. Broth tube dilution method as suggested by CLSI adopted from Stephanie de Rapper et al. 2013 with some modifications. The stock solution was prepared for each essential oil by taking $32 \mathrm{ul}$ of essential oil was diluted in $1 \mathrm{ml}$ of $5 \%$ acetone $(\mathrm{v} / \mathrm{v})$ at the starting dilution volume of $32 \mathrm{ul}$ based on specific gravity essential oil actual concentration was computed in $\mathrm{mg} / \mathrm{ml}$ by 
assuming essential oils are 100\% pure (Table 3.2). Further two-fold serial dilutions of the stock essential oil solution yielded dilution volumes of 16, 8, 4, 2, 1, and 0.5ul (Fig. 7B). A control tube of $5 \%$ Tween $+5 \%$ acetone + bacterial suspension without essential oil was used as a reference. The bacterial culture in a log phase growth was diluted in Tryptic Soy Broth (TSB) to achieve 0.5 McFarland standard and then spread plated onto the R2A plate. All plates were incubated at room temperature for 72 hours, and all experiments were done in triplicate.

\subsection{Wastewater Sample Test Assay}

The seven wastewater samples such as aeration tank (AT-2, AT-4, AT-6, AT-8), digesters (DIG1, DIG-2), and Return Sludge (RS) containing mixed population of different bacteria was tested against three essential oils such as clove oil, cinnamon oil, and oregano oil. The three essential oils were screened for their bacterial growth inhibitory activity. A 200 ul aliquot of each raw wastewater sample was mixed with $100 \mu \mathrm{l}$ distilled water. The mixture (100 $\mu \mathrm{l})$ was spread plated on R2A and prepared filter discs, $(6 \mathrm{~mm})$ immersed with the essential oil at their MIC cons. clove $0.52 \mathrm{mg} / \mathrm{ml}$, cinnamon oil $0.51 \mathrm{mg} / \mathrm{ml}$ and oregano $0.47 \mathrm{mg} / \mathrm{ml}$ were placed on it as described by the Kirby-Bauer Disc diffusion assay with slight modifications (Fig. 7C). The Petri plates were then incubated in an upright position at room temperature for 72 hours. The experiment was conducted in triplicate. 


\section{CHAPTER FOUR}

\section{RESULTS}

\subsection{Preliminary Screening of Plant Essential Oils.}

\subsubsection{Wild Type Bacterial Pure Cultures}

The susceptibility of ten wild type bacterial pure cultures was determined against six plant essential oils and the results are shown in Table 4.1. The degree of sensitivity was determined by using the Kirby-Bauer disc diffusion assay as standardized by NCCLS 2014 and the susceptibility measurements provided by the manufacturer $\left(\mathrm{BBL}^{\mathrm{TM}} \mathrm{Taxo}^{\mathrm{TM}} 13 \mathrm{~mm}\right.$ disc) were adopted as resistant to very sensitive. Results showed that Staphylococcus aureus was very sensitive $(+++)$ to five of the essential oils and sensitive $(++)$ to tea tree oil with zones of inhibition halos recorded based on triplicate results (Table 4.1; Appendix A, C, D, E, F \& G). Acinetobacter baumanii showed sensitivity to clove oil, cinnamon, and oregano oil and showed lesser to no sensitivity to fennel, tea tree, and wintergreen oils. Three E.coli strains were used and showed some variation in sensitivity. E.coli: AD202 was very sensitive to clove and cinnamon oils, less inhibited by oregano and fennel oils and less to no inhibition to tea tree and wintergreen oils. The two strains of E.coli:DH5 $\alpha$ were very sensitive to clove and cinnamon oils but showed less inhibition to the other four oils. Pseudomonas fluorescens was found to be very sensitive $(+++)$ to sensitive $(++)$ to clove oil, cinnamon oil, and oregano oil but less so to the other three oils. Pseudomonas poae was very sensitive to cinnamon oil, oregano oil, clove oil and tea tree oil. Similarly, Pseudomonas putida also was very sensitive $(+++)$ to sensitive $(++)$ against cinnamon oil, wintergreen oil, and clove oil. The two strains of Stenotrophomonas maltophilia were sensitive to cinnamon and clove and a lesser extent to tea tree oil for one and oregano for the other. Based on these results, it appeared that clove oil, cinnamon oil, and oregano oil were the most effective at inhibiting the growth of a variety of both Gram positive and Gram negative bacteria. The control 5\% acetone and vegetable oil did not show any antibacterial activity (Table 4.1; Appendix J). 
Table 4.1. Wild Type Bacterial Sensitivity to Clove, Cinnamon, Oregano, Fennel, Tea tree and Winter green Essential Oils Determined by a Disc Diffusion Assay.

\begin{tabular}{|c|c|c|c|c|c|c|c|}
\hline \multirow{4}{*}{ Bacterial Strains } & \multirow{2}{*}{\multicolumn{7}{|c|}{$\begin{array}{l}\text { Essential Oils Used } \\
\text { Zones of Inhibition in ( } \mathrm{mm})\end{array}$}} \\
\hline & & & & & & & \\
\hline & \multirow{2}{*}{$\begin{array}{l}\text { Clove } \\
(52 \mathrm{mg} / \mathrm{ml})\end{array}$} & \multirow{2}{*}{$\begin{array}{c}\text { Cinnamon } \\
(51.5 \mathrm{mg} / \mathrm{ml})\end{array}$} & \multirow{2}{*}{$\begin{array}{c}\text { Oregano } \\
(47 \mathrm{mg} / \mathrm{ml})\end{array}$} & \multirow{2}{*}{$\begin{array}{l}\text { Fennel } \\
(48 \mathrm{mg} / \mathrm{ml})\end{array}$} & \multirow{2}{*}{$\begin{array}{l}\text { Teatree } \\
(44.5 \mathrm{mg} / \mathrm{ml})\end{array}$} & \multirow{2}{*}{$\begin{array}{c}\text { Winter } \\
\text { Green } \\
(59 \mathrm{mg} / \mathrm{ml})\end{array}$} & Control \\
\hline & & & & & & & $\begin{array}{ll}\text { ve } & 5 \% \\
\mathrm{~g} & \text { Acetone } \\
\text { Oil } & \text { Acen } \\
\end{array}$ \\
\hline Acinetobacter baumanii (27) & ++ & ++ & +++ & + & - & + & - \\
\hline E.coli:DH5 $\infty(17)$ & ++ & +++ & - & ++ & - & - & - \\
\hline E.coli:AD202 (36) & +++ & +++ & + & + & - & - & - \\
\hline E.coli:DH5 & ++ & +++ & - & + & - & - & - \\
\hline Pseudomonas fluorescens (8) & +++ & +++ & ++ & + & - & - & - \\
\hline Pseudomonas poae (26) & +++ & +++ & +++ & + & +++ & + & - \\
\hline Pseudomonas putida (BBL-443) & ++ & ++ & + & + & + & +++ & - \\
\hline Staphylococus aureus (16) & +++ & +++ & +++ & +++ & ++ & +++ & - \\
\hline Stenotrophomonas maltophilia (13) & ++ & + & + & ++ & ++ & +++ & - \\
\hline Stenotrophomonas maltophilia (33) & ++ & +++ & + & + & + & ++ & - \\
\hline $\begin{array}{l}\text { Total Sensitive (ZOI> } 15 \mathrm{~mm}) \\
\text { Total Resistant }(\mathrm{ZOI}<15 \mathrm{~mm})\end{array}$ & $\begin{array}{l}\text { S-10 } \\
\text { R-0 }\end{array}$ & $\begin{array}{c}\text { S-10 } \\
\text { R-0 }\end{array}$ & $\begin{array}{l}\text { S-8 } \\
\text { R-2 }\end{array}$ & $\begin{array}{l}\text { S-10 } \\
\text { R-0 }\end{array}$ & $\begin{array}{l}\text { S-5 } \\
\text { R-5 }\end{array}$ & $\begin{array}{l}\text { S-6 } \\
\text { R-4 }\end{array}$ & $\begin{array}{c}\text { S-0 } \\
\text { R-10 }\end{array}$ \\
\hline \begin{tabular}{ll}
\multicolumn{2}{l}{ Sensitivity Index } \\
$-\quad$ Bacteria Not Sensitive \\
$+\quad$ Intermediate Sensitive \\
++ & Bacteria Sensitive \\
++ & Bacteria Very Sensitive
\end{tabular} & & & & & & & \\
\hline
\end{tabular}




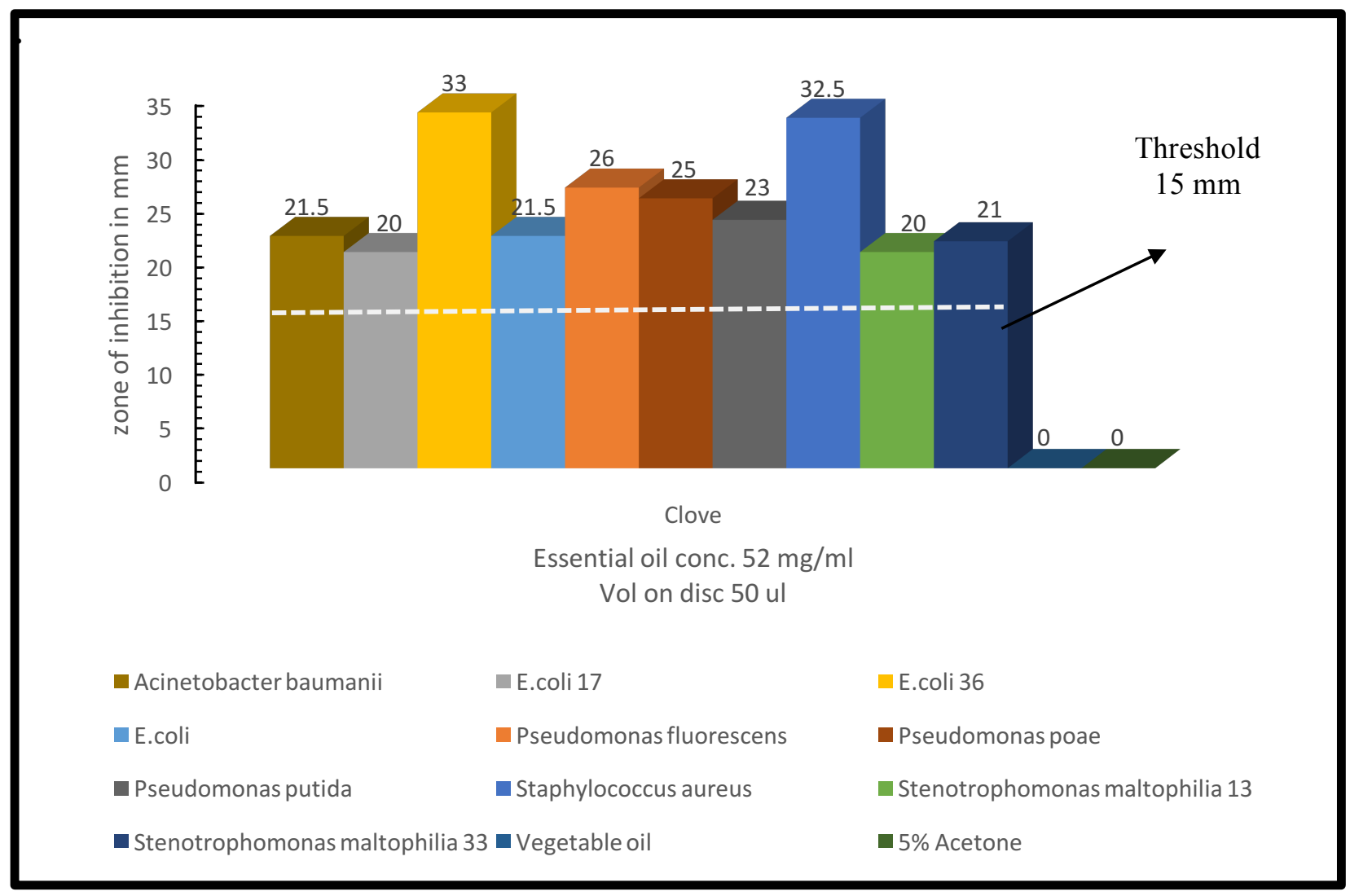

Figure 9. Wild type Bacterial Strain Sensitivity to Cinnamon Essential Oil Determined by Disc Diffusion Assay. 


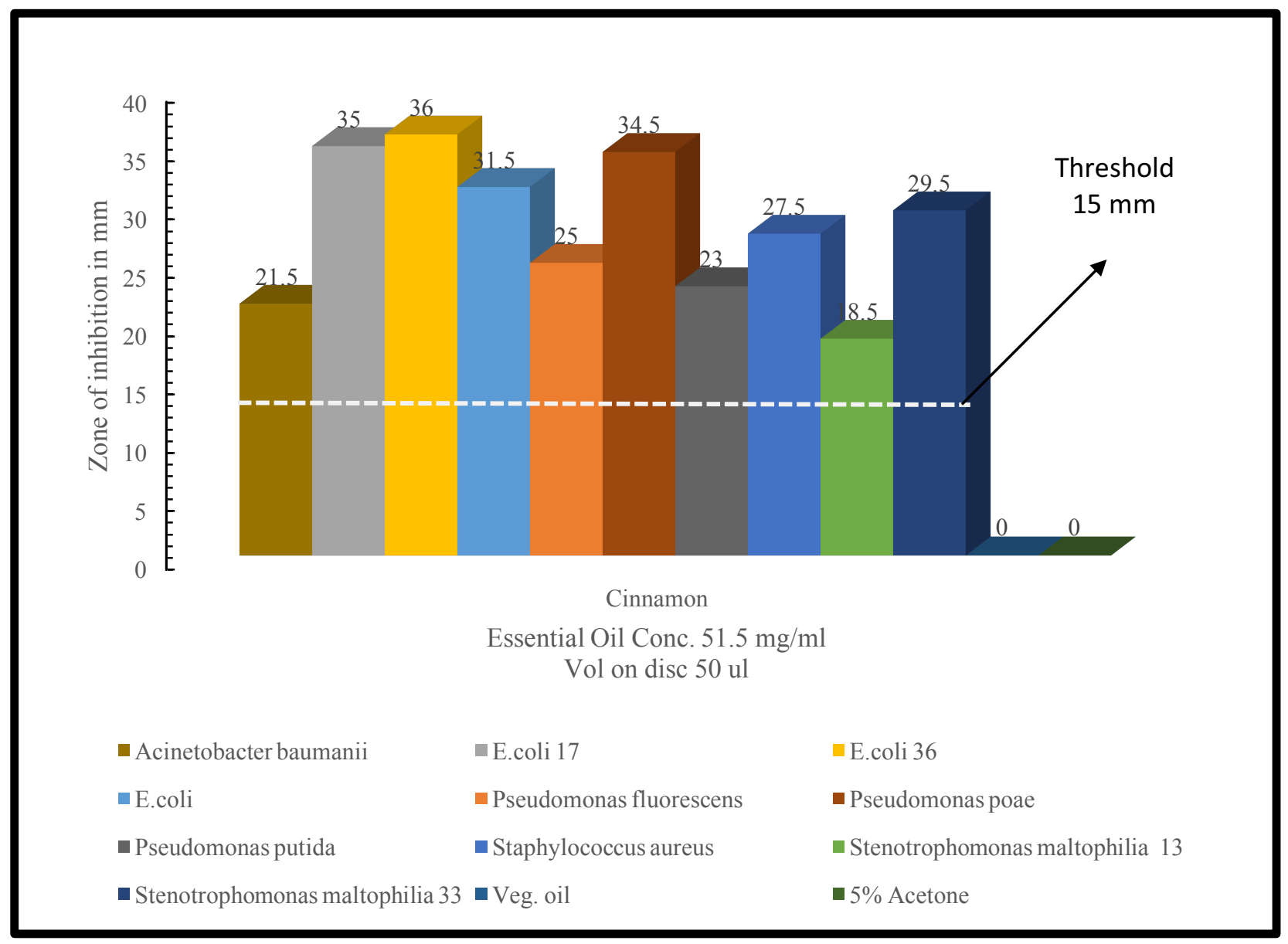

Figure 10. Wild type Bacterial Strain Sensitivity to Cinnamon Essential Oil Determined by Disc Diffusion Assay. 


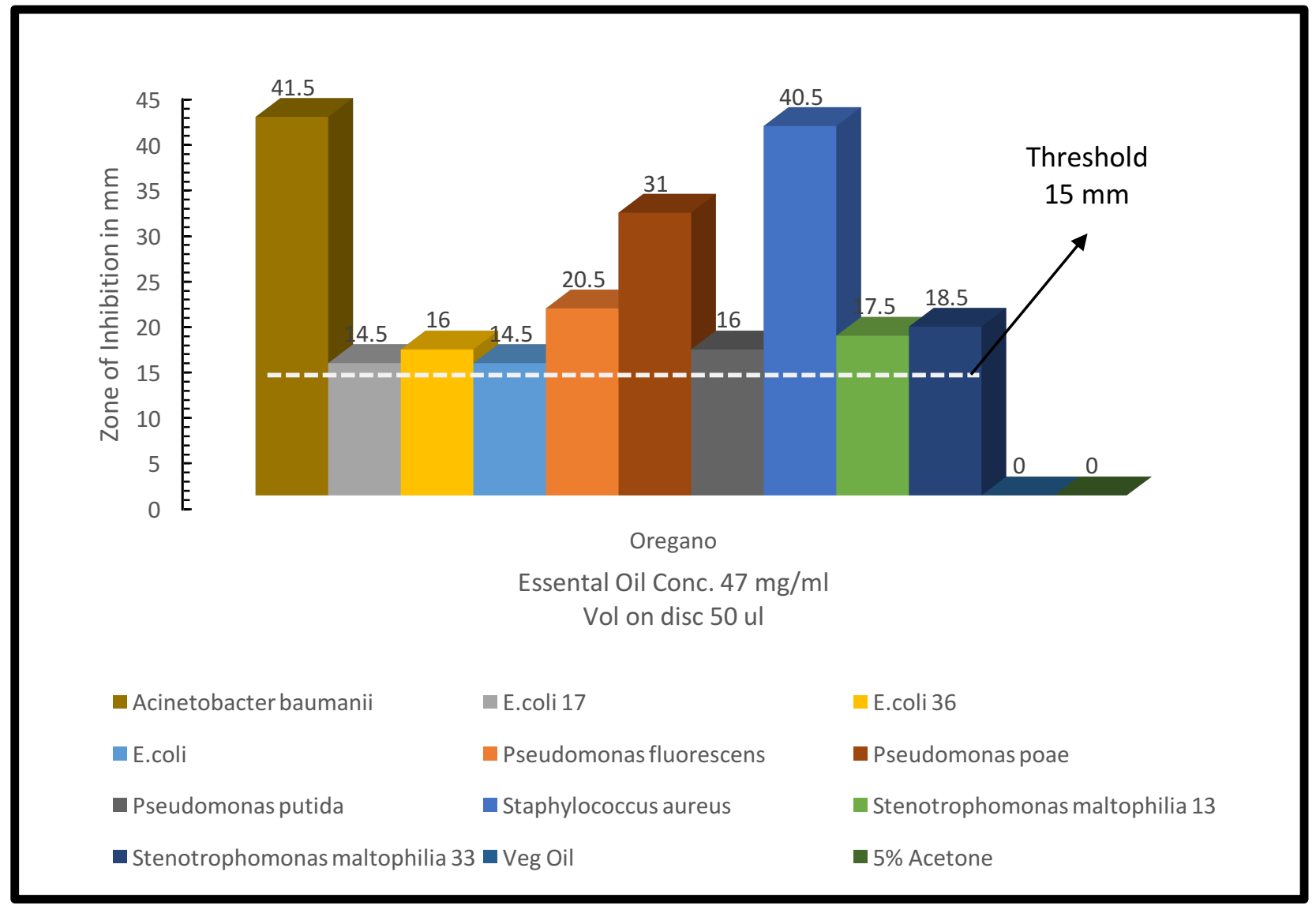

Figure 11. Wild type Bacterial Strain Sensitivity to Oregano Essential Oil Determined by Disc Diffusion Assay. 


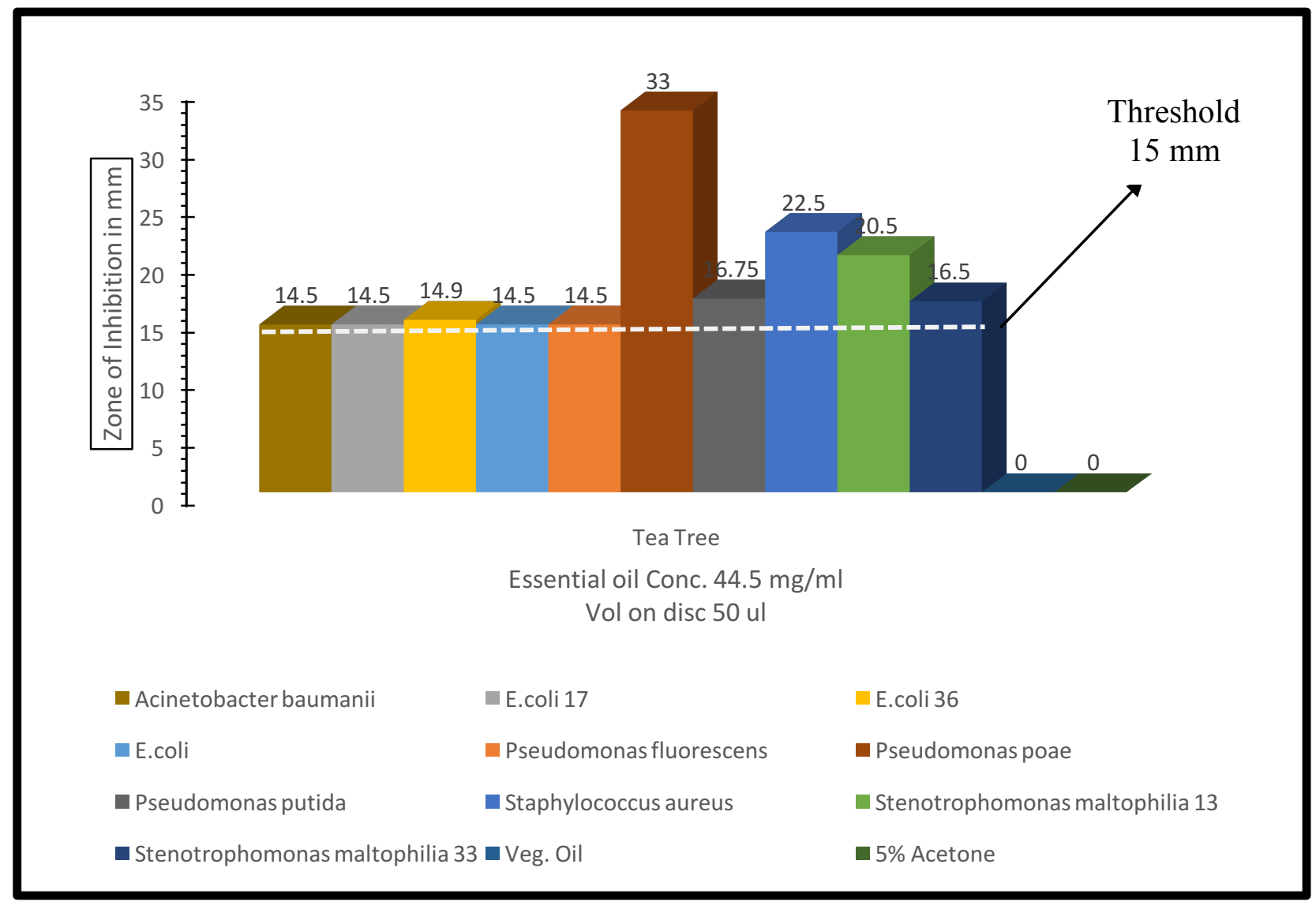

Figure 12. Wild type Bacterial Strain Sensitivity to Tea tree Essential Oil Determined by Disc Diffusion Assay. 


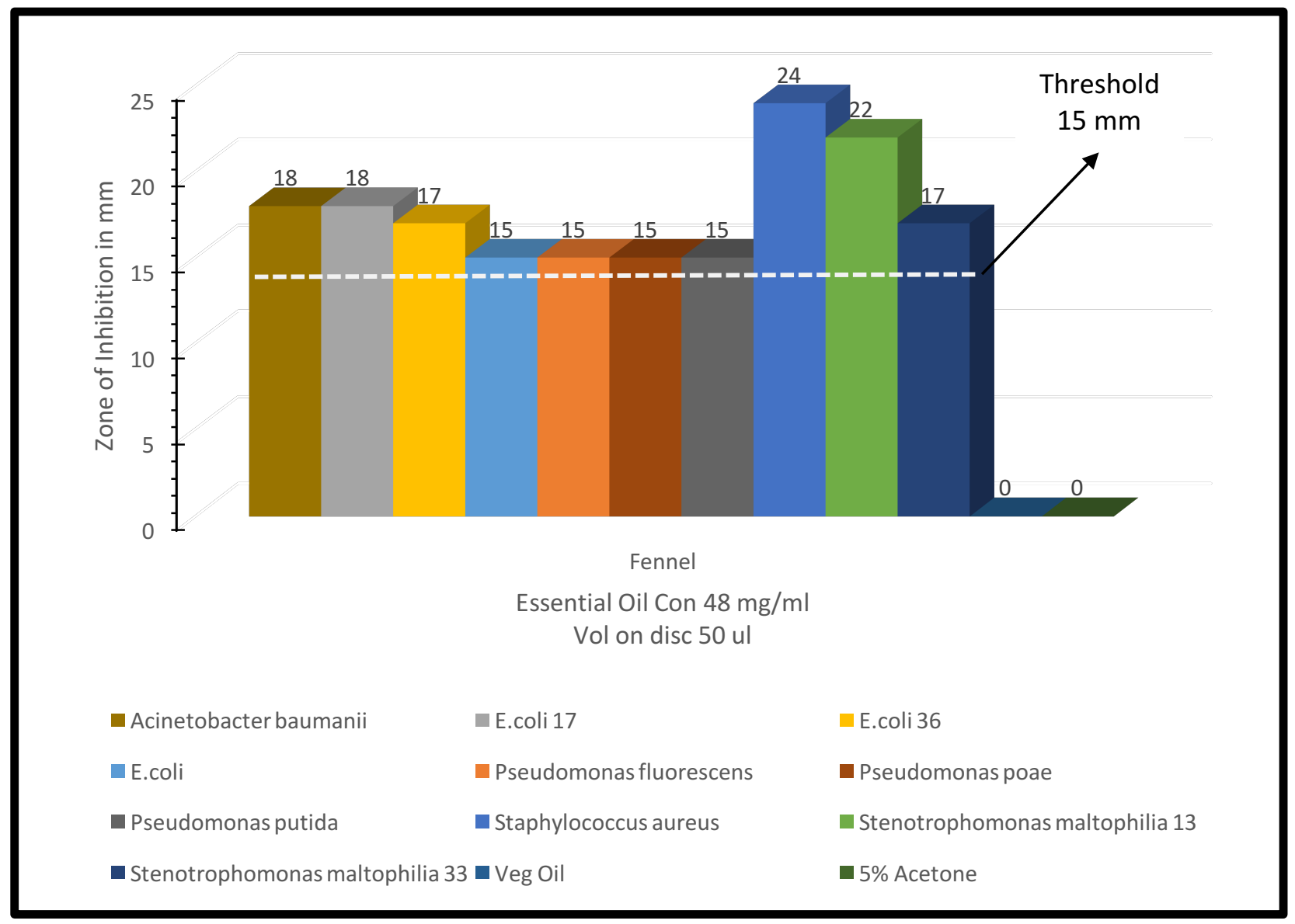

Figure 13. Wild type Bacterial Strain Sensitivity to Fennel Essential Oil Determined by Disc Diffusion Assay. 


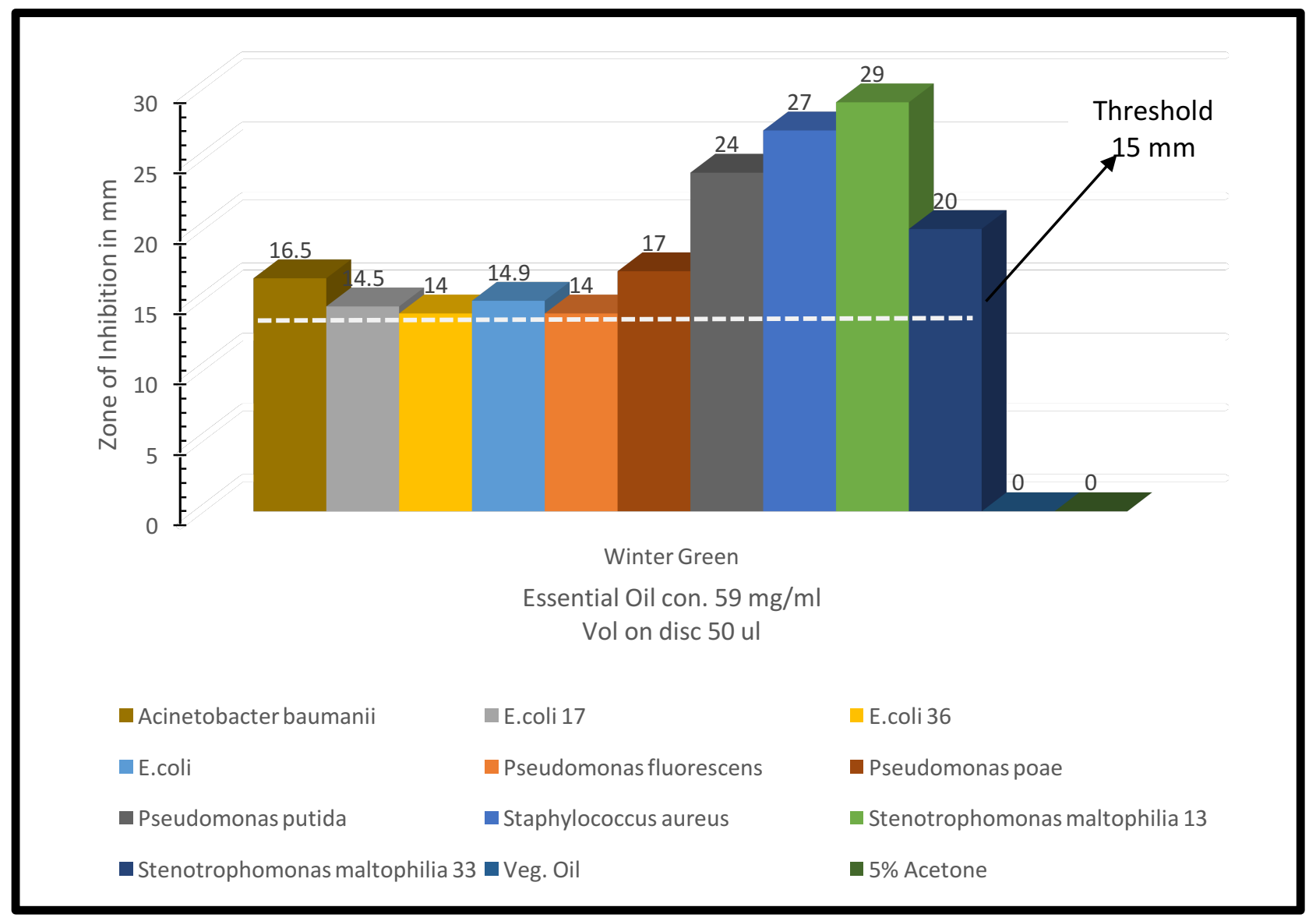

Figure 14. Wild type Bacterial Strain Sensitivity to Wintergreen Essential Oil Determined by Disc Diffusion Assay. 


\subsubsection{Wastewater isolated bacterial strains}

In the case of ten wastewater isolated bacterial strains, sensitivity was determined against three of the plant essential oils such as clove, cinnamon and oregano, results are shown in (Table 4.2; Appendix B, H, I and J). The degree of sensitivity was determined by using the Kirby-Bauer method as standardized by NCCLS 2014.

The wastewater isolated bacterial strains such as Acinetobacter baumanii, Acinetobacter bouretii, Aeromonas hydrophilla, E. coli, Flavobacterium barchiophillum, Klebsiella pneumonii, Serratia fonticola, Staphylococcus muscae, Pseudomonas staurtii were very sensitive to all three essential oils. One exception was Enterobacter cloaceae that was found to be very sensitive $(+++)$ to clove oil, cinnamon oil but only sensitive $(++)$ to oregano oil. Based on these results, it appeared that clove oil, cinnamon oil, and oregano oil were the most effective at inhibiting the growth of a variety of both Gram positive and Gram negative bacteria. All experiments were done in triplicate with the mean \pm S.E (Standard Error) values of the zones of inhibition halos in mm to clove, cinnamon, oregano. The complete results are presented in the Appendix B. 
Table 4.2. Wastewater Isolated Bacterial Sensitivity to Clove, Cinnamon and Oregano Essential Oils as Determined by Disc Diffusion Assay.

\begin{tabular}{|c|c|c|c|c|c|}
\hline \multirow{4}{*}{ Bacteria } & \multirow{2}{*}{\multicolumn{3}{|c|}{$\begin{array}{l}\text { Essential Oils Used } \\
\text { Zones of Inhibition in (mm) }\end{array}$}} & & \\
\hline & & & & & \\
\hline & \multirow{2}{*}{$\begin{array}{c}\text { Clove } \\
\text { (52 mg) }\end{array}$} & \multirow{2}{*}{$\underset{(51.5 \mathrm{mg})}{\operatorname{Cinnamon}}$} & \multirow{2}{*}{$\underset{(47 \mathrm{mg})}{\text { Oregano }}$} & \multicolumn{2}{|c|}{ Control } \\
\hline & & & & Veg Oil & $\begin{array}{c}5 \% \\
\text { Acetone }\end{array}$ \\
\hline Acinetobacter baumanii (12K) & +++ & +++ & +++ & - & - \\
\hline Acinetobacter bouretii (10A) & +++ & +++ & +++ & - & - \\
\hline Aeromonas hydrophilla (7A) & +++ & +++ & +++ & - & - \\
\hline E. coli (36) & +++ & +++ & +++ & - & - \\
\hline Enterobacter cloaceae (12E) & +++ & +++ & ++ & - & - \\
\hline Flavobacterium branchiophilum (8I) & +++ & +++ & +++ & - & - \\
\hline Klebsiella pneumoniae (11A) & +++ & +++ & +++ & - & - \\
\hline Pseudomonas staurtii (14D) & +++ & +++ & +++ & - & - \\
\hline Staphylococcus muscae (15D) & +++ & +++ & +++ & - & - \\
\hline Serratia fonticola (4B) & +++ & +++ & +++ & - & - \\
\hline $\begin{array}{l}\text { Total Sensitive (ZOI }>15 \mathrm{~mm}) \\
\text { Total Resistant }(\mathrm{ZOI}<15 \mathrm{~mm})\end{array}$ & $\begin{array}{l}\text { S-10 } \\
\text { R-0 }\end{array}$ & $\begin{array}{l}\text { S-10 } \\
\text { R-0 }\end{array}$ & $\begin{array}{l}\text { S-10 } \\
\text { R-0 }\end{array}$ & $\begin{array}{c}\text { S-0 } \\
\text { R-10 }\end{array}$ & $\begin{array}{c}\text { S-0 } \\
\text { R-10 }\end{array}$ \\
\hline
\end{tabular}

\section{Sensitivity Index}

- $\quad$ Bacteria Not Sensitive

+ Intermediate Sensitive

++ Bacteria Sensitive

+++ Bacteria Very Sensitive 


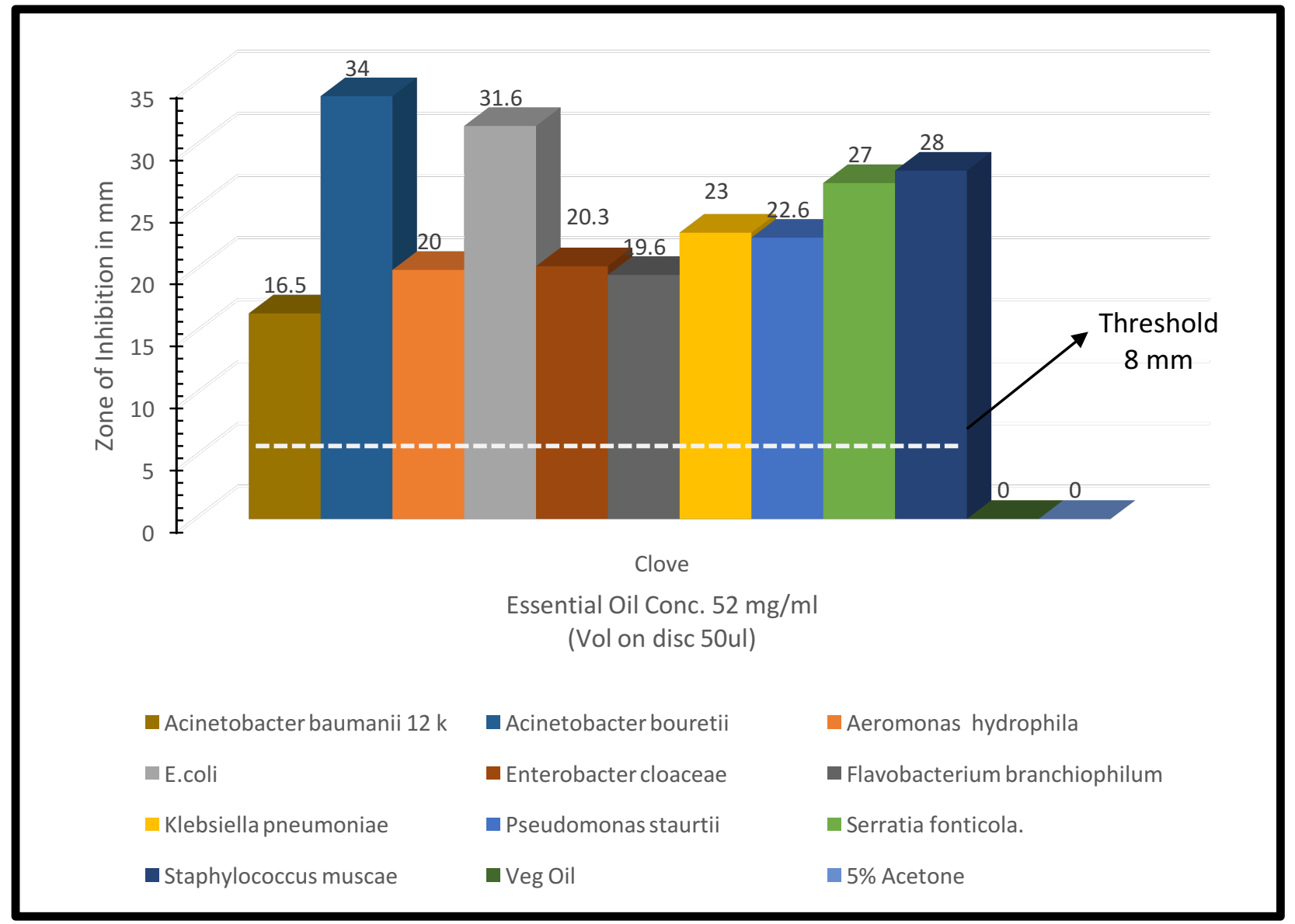

Figure 15. Wastewater Isolated Bacterial Strains Sensitivity to Clove Essential Oil Determined by Disc Diffusion Method. 


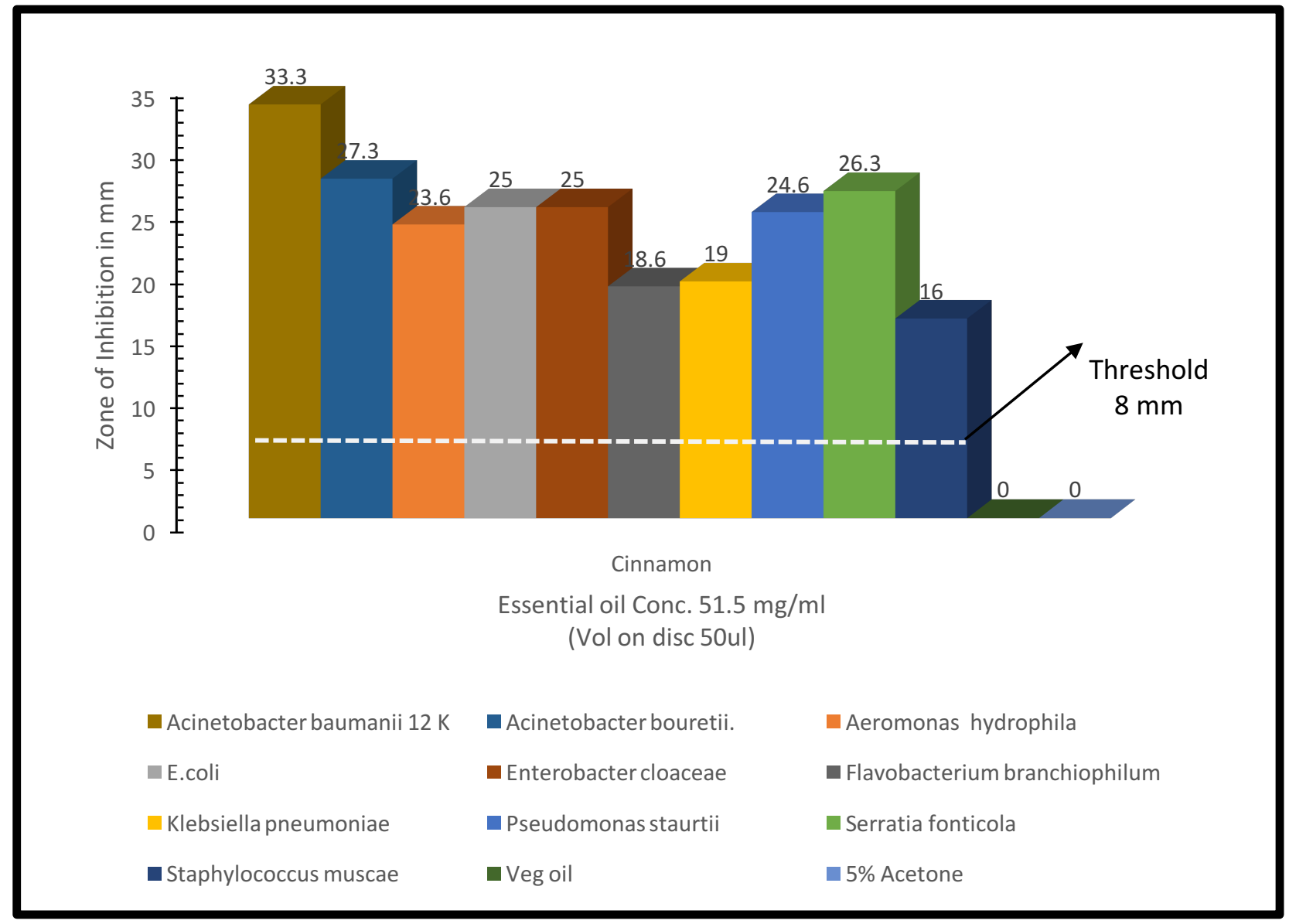

Figure 16. Wastewater Isolated Bacterial Strains Sensitivity to Cinnamon Essential Oil Determined by Disc Diffusion Method. 


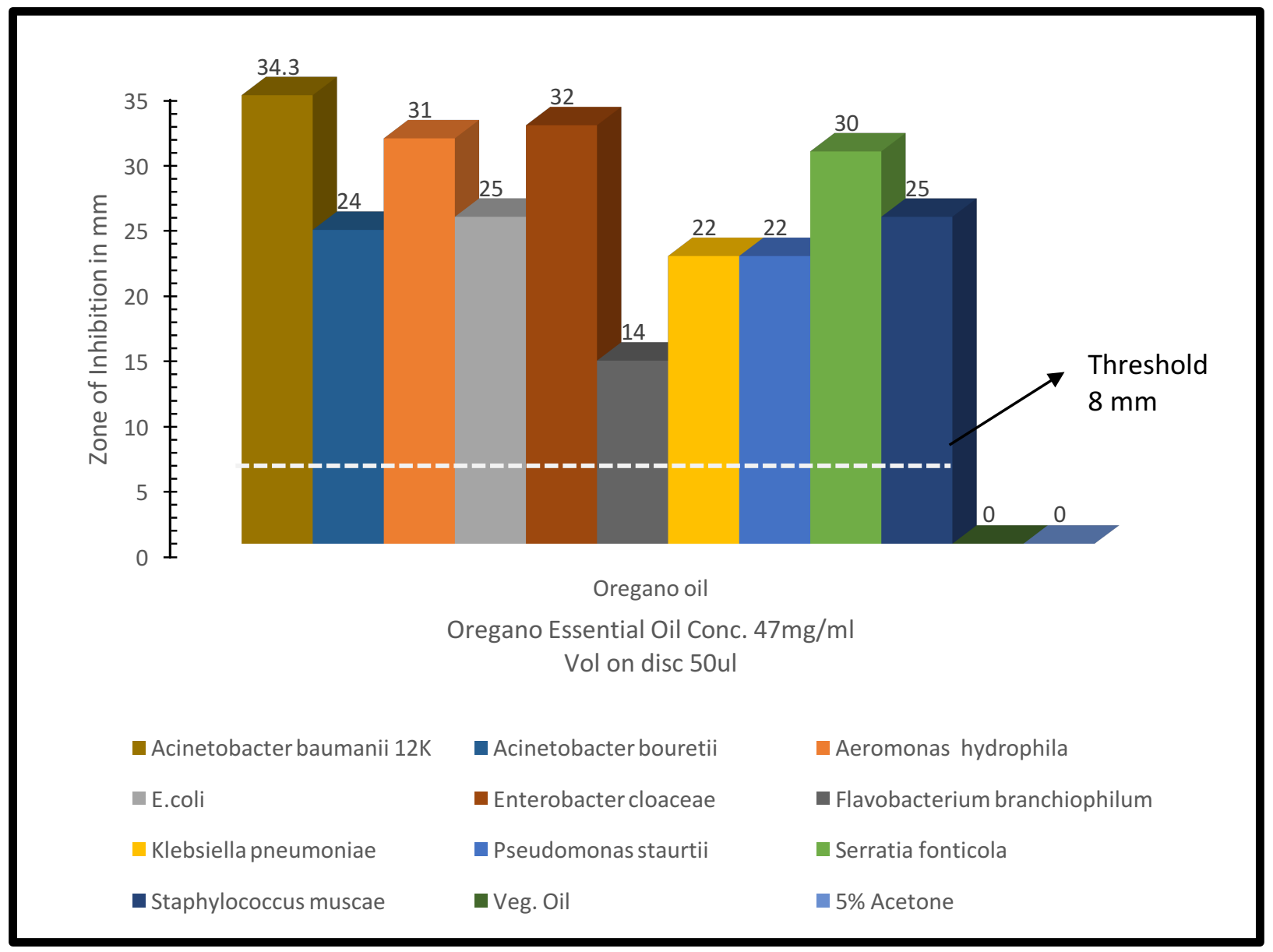

Figure 17. Wastewater Isolated Bacterial Strains Sensitivity to Oregano Essential Oil Determined by Disc Diffusion Method. 


\subsection{Minimum Inhibitory Concentration (MIC)}

The minimum inhibitory concentration required to show inhibition of bacterial growth was determined for the three essential oils that were effective against the wastewater bacterial strains. The MIC for clove, cinnamon, oregano oils was determined by employing broth tube macro dilution method as outlined by NCCLS 2014. The results are shown in Tables 4.3, 4.4, 4.5 and 4.6.

\subsubsection{Minimum Inhibitory Concentration of Clove Essential Oil}

Among the wastewater isolated bacterial strains assayed E. coli, Staphylococcus muscae, Enterobacter cloaceae, Acinetobacter baumanii were found to be most sensitive to clove oil with a minimum inhibitory concentration of $0.52 \mathrm{mg} / \mathrm{ml}$ followed by Klebsiella pneumoniae with a MIC of $1.04 \mathrm{mg} / \mathrm{ml}$. Aeromonas hydrophila and Acinetobacter bouretii both showed a MIC of $2.08 \mathrm{mg} / \mathrm{ml}$ whereas Pseudomonas staurtii, and Serratia fonticola were comparitively less sensitive with a minimum inhibitory concentration of $4.16 \mathrm{mg} / \mathrm{ml}$ (Tables 4.3 and 4.6; Appendix $\mathrm{K}, \mathrm{L})$.

\subsubsection{Minimum Inhibitory Concentration of Cinnamon Essential Oil}

Among the wastewater isolated bacteria assayed E. coli, Enterobacter cloaceae, Acinetobacter baumanii were found to be most sensitive to Cinnamon with a MIC of $0.51 \mathrm{mg} / \mathrm{ml}$ followed by Acinetobacter bouretii with a MIC of $1.03 \mathrm{mg} / \mathrm{ml}$. Aeromonas hydrophila, Pseudomonas staurtii were comparitively less sensitive with MIC of $4.12 \mathrm{mg}$ followed by Staphylococcus muscae, Serratia fonticola, Klebsiella pneumoniae with MICs of $8.24 \mathrm{mg} / \mathrm{ml}$ respectively (Tables 4.4 and 4.6; Appendix K, L).

\subsubsection{Minimum Inhibitory Concentration of Oregano Essential Oil}

Among the wastewater isolated bacteria assayed E. coli, Staphylococcus muscae, Enterobacter cloaceae, Acinetobacter baumanii were found to be most sensitive with a MIC of $0.47 \mathrm{mg} / \mathrm{ml}$ followed by Serratia fonticola, Klebsiella pneumoniae, Acinetobacter bouretii with MICs of 3.76 $\mathrm{mg} / \mathrm{ml}$ whereas Aeromonas hydrophila was the least sensitive of all other bacterial strains with a MIC of $30.08 \mathrm{mg} / \mathrm{ml}$ (Tables 4.5 and 4.6; Appendix K, L). 
Table. 4.3. Wastewater Isolated Bacterial Strains Sensitivity to Clove Oil by Employing Broth Tube Macro-dilution MIC Assay.

\begin{tabular}{|c|c|c|c|c|c|c|c|c|}
\hline \multirow[b]{2}{*}{ Bacteria } & \multicolumn{8}{|c|}{ Clove Oil Concentration/ Volume Taken } \\
\hline & $\begin{array}{c}33.28 \\
\mathrm{mg} / \mathrm{ml} \\
(32 \mathrm{ul})\end{array}$ & $\begin{array}{c}16.64 \\
\mathrm{mg} / \mathrm{ml} \\
(16 \mathrm{ul})\end{array}$ & $\begin{array}{r}8.32 \\
\mathrm{mg} / \mathrm{ml} \\
(8 \mathrm{ul})\end{array}$ & $\begin{array}{r}4.16 \\
\mathrm{mg} / \mathrm{ml} \\
(4 \mathrm{ul})\end{array}$ & $\begin{array}{r}2.08 \\
\mathrm{mg} / \mathrm{ml} \\
(2 \mathrm{ul})\end{array}$ & $\begin{array}{c}1.04 \\
\mathrm{mg} / \mathrm{ml} \\
(1 \mathrm{ul})\end{array}$ & $\begin{array}{c}0.52 \\
\mathrm{mg} / \mathrm{ml} \\
(0.5 \mathrm{ul})\end{array}$ & $\begin{array}{c}\text { Control } \\
5 \% \text { Polyso } \\
\text { rbate } 80\end{array}$ \\
\hline Acinetobacter baumanii (10A) & - & - & - & - & - & - & - & + \\
\hline Acinetobacter bouretii (12K) & - & - & - & - & - & + & + & + \\
\hline Aeromonas hydrophila (7A) & - & - & - & - & - & + & + & + \\
\hline E. $\operatorname{coli}(36)$ & - & - & - & - & - & - & - & + \\
\hline Enterobacter cloaceae (12E) & - & - & - & - & - & - & - & + \\
\hline Flavobacterium branchiophilum (8I) & - & - & - & - & - & - & - & + \\
\hline Klebsiella pneumoniae (11A) & - & - & - & - & - & - & + & + \\
\hline Pseudomonas staurtii (17D) & - & - & - & - & + & + & + & + \\
\hline Serratia fonticola (4B) & - & - & - & - & + & + & + & + \\
\hline Staphylococcus muscae (15D) & - & - & - & - & - & - & - & + \\
\hline $\begin{array}{l}\text { Total Sensitive } \\
\text { Total Resistant }\end{array}$ & $\begin{array}{l}\text { S-10 } \\
\text { R-0 }\end{array}$ & $\begin{array}{l}\text { S-10 } \\
\text { R-0 }\end{array}$ & $\begin{array}{l}\text { S-10 } \\
\text { R-0 }\end{array}$ & $\begin{array}{l}\text { S-10 } \\
\text { R-0 }\end{array}$ & $\begin{array}{l}\text { S-8 } \\
\text { R-2 }\end{array}$ & $\begin{array}{l}\text { S-6 } \\
\text { R-4 }\end{array}$ & $\begin{array}{l}\text { S-5 } \\
\text { R-5 }\end{array}$ & $\begin{array}{l}\text { S-0 } \\
\text { R-10 }\end{array}$ \\
\hline
\end{tabular}

\section{- No Bacterial Growth \\ + Bacterial Growth}


Table. 4.4. Wastewater Isolated Bacterial Sensitivity to Cinnamon oil by Employing Broth Tube Macro-dilution MIC Assay.

\begin{tabular}{|c|c|c|c|c|c|c|c|c|}
\hline \multirow[b]{2}{*}{ Bacteria } & \multicolumn{8}{|c|}{ Cinnamon Oil Concentration/ Volume Taken } \\
\hline & $\begin{array}{l}32.96 \\
\mathrm{mg} / \mathrm{ml} \\
(32 \mathrm{ul})\end{array}$ & $\begin{array}{l}16.4 \\
\mathrm{mg} / \mathrm{ml} \\
(16 \mathrm{ul})\end{array}$ & $\begin{array}{l}8.2 \\
\mathrm{mg} / \mathrm{ml} \\
(8 \mathrm{ul})\end{array}$ & $\begin{array}{l}4.12 \\
\mathrm{mg} / \mathrm{ml} \\
(4 \mathrm{ul})\end{array}$ & $\begin{array}{l}2.06 \\
\mathrm{mg} / \mathrm{ml} \\
(2 \mathrm{ul})\end{array}$ & $\begin{array}{l}1.03 \\
\mathrm{mg} / \mathrm{ml} \\
(\mathbf{l u l})\end{array}$ & $\begin{array}{l}0.51 \\
\mathrm{mg} / \mathrm{ml} \\
(0.5 \mathrm{ul})\end{array}$ & $\begin{array}{l}\text { Control } \\
5 \% \text { Polys } \\
\text { rbate } 80\end{array}$ \\
\hline Acinetobacter baumanii (10A) & - & - & - & - & - & - & - & + \\
\hline Acinetobacter bouretii (12K) & - & - & - & - & - & - & + & + \\
\hline Aeromonas hydrophila(7A) & - & - & - & - & + & + & + & + \\
\hline E. $\operatorname{coli}(36)$ & - & - & - & - & - & - & - & + \\
\hline Enterobacter cloaceae (12E) & - & - & - & - & - & - & - & + \\
\hline Flavobacterium branchiophilum(8I) & - & - & - & - & - & - & - & + \\
\hline Klebsiella pneumoniae (11A) & - & - & - & + & + & + & + & + \\
\hline Pseudomonas staurtii (17D) & - & - & - & - & + & + & + & + \\
\hline Serratia fonticola (4B) & - & - & - & + & + & + & + & + \\
\hline Staphylococcus muscae(15D) & - & - & - & + & + & + & + & + \\
\hline $\begin{array}{l}\text { Total Sensitive } \\
\text { Total Resistant }\end{array}$ & $\begin{array}{l}\text { S-10 } \\
\text { R-0 }\end{array}$ & $\begin{array}{l}\text { S-10 } \\
\text { R-0 }\end{array}$ & $\begin{array}{l}\text { S-10 } \\
\text { R-0 }\end{array}$ & $\begin{array}{l}\text { S-7 } \\
\text { R-3 }\end{array}$ & $\begin{array}{l}\text { S-5 } \\
\text { R-5 }\end{array}$ & $\begin{array}{l}\text { S-5 } \\
\text { R-5 }\end{array}$ & $\begin{array}{l}\text { S-4 } \\
\text { R-6 }\end{array}$ & $\begin{array}{c}\text { S-0 } \\
\text { R-10 }\end{array}$ \\
\hline
\end{tabular}

\section{- No Bacterial Growth \\ + Bacterial Growth}


Table. 4.5. Wastewater Isolated Bacterial Sensitivity to Oregano Oil by Employing Broth

Tube Macro-dilution MIC Assay.

\begin{tabular}{|c|c|c|c|c|c|c|c|c|}
\hline \multirow[b]{2}{*}{ Bacteria } & \multicolumn{8}{|c|}{ Oregano Oil Concentration/ Volume Taken } \\
\hline & $\begin{array}{c}30.08 \\
\mathrm{mg} / \mathrm{ml} \\
(32 \mathrm{ul})\end{array}$ & $\begin{array}{c}15.04 \\
\mathrm{mg} / \mathrm{ml} \\
(16 \mathrm{ul})\end{array}$ & $\begin{array}{c}7.52 \\
\mathrm{mg} / \mathrm{ml} \\
(8 \mathrm{ul})\end{array}$ & $\begin{array}{c}3.76 \\
\mathrm{mg} / \mathrm{ml} \\
(4 \mathrm{ul})\end{array}$ & $\begin{array}{c}1.88 \\
\mathrm{mg} / \mathrm{ml} \\
(2 \mathrm{ul})\end{array}$ & $\begin{array}{c}0.94 \\
\mathrm{mg} / \mathrm{ml} \\
(1 \mathrm{ul})\end{array}$ & $\begin{array}{c}0.47 \\
\mathrm{mg} / \mathrm{ml} \\
(0.5 \mathrm{ul})\end{array}$ & $\begin{array}{c}\text { Control } \\
5 \% \text { Polys } \\
\text { orbate } \\
80\end{array}$ \\
\hline Acinetobacter baumanii (10A) & - & - & - & - & - & - & - & + \\
\hline Acinetobacter bouretii (12K) & - & - & - & - & + & + & + & + \\
\hline Aeromonas hydrophila (7A) & - & + & + & + & + & + & + & + \\
\hline E. $\operatorname{coli}(36)$ & - & - & - & - & - & - & - & + \\
\hline Enterobacter cloaceae (12E) & - & - & - & - & - & - & - & + \\
\hline Flavobacterium branchiophilum (8I) & - & - & - & - & - & - & - & + \\
\hline Klebsiella pneumoniae (11A) & - & - & - & - & - & + & + & + \\
\hline Pseudomonas staurtii (17D) & - & - & - & - & + & + & + & + \\
\hline Serratia fonticola (4B) & - & - & - & - & - & + & + & + \\
\hline Staphylococcus muscae (15D) & - & - & - & - & - & - & - & + \\
\hline $\begin{array}{l}\text { Total Sensitive } \\
\text { Total Resistant }\end{array}$ & $\begin{array}{l}\text { S-10 } \\
\text { R-0 }\end{array}$ & $\begin{array}{l}\text { S-9 } \\
\text { R-1 }\end{array}$ & $\begin{array}{l}\text { S-9 } \\
\text { R-1 }\end{array}$ & $\begin{array}{l}\text { S-9 } \\
\text { R-1 }\end{array}$ & $\begin{array}{l}\text { S-7 } \\
\text { R-3 }\end{array}$ & $\begin{array}{l}\text { S-5 } \\
\text { R-5 }\end{array}$ & $\begin{array}{l}\text { S-5 } \\
\text { R-5 }\end{array}$ & $\begin{array}{c}\text { S-0 } \\
\text { R-10 }\end{array}$ \\
\hline
\end{tabular}

- No Bacterial Growth

+ Bacterial Growth 
Table 4.6. Wastewater Isolated Bacterial Sensitivity to Clove, Cinnamon and Oregano oils based on Broth Tube Macro-dilution MIC Assay.

\begin{tabular}{|c|c|c|c|c|c|}
\hline \multirow[b]{3}{*}{ Bacteria } & \multicolumn{5}{|c|}{ Essential Oils Used } \\
\hline & \multirow[t]{2}{*}{ Clove } & \multirow[t]{2}{*}{$\begin{array}{c}\text { MIC in } \mathrm{mg} / \mathrm{ml} \\
\text { Cinnamon }\end{array}$} & \multirow[t]{2}{*}{ Oregano } & \multicolumn{2}{|c|}{ Control } \\
\hline & & & & $\begin{array}{l}\text { Veg } \\
\text { Oil }\end{array}$ & $\begin{array}{l}5 \% \\
\text { Acetone }\end{array}$ \\
\hline Acinetobacter baumanii (12K) & $0.52 \leq$ & $0.51 \leq$ & $0.47 \leq$ & - & - \\
\hline Acinetobacter bouretii (10A) & 2.08 & 1.03 & 3.76 & - & - \\
\hline Aeromonas hydrophila (7A) & 2.08 & 4.12 & 30.08 & - & - \\
\hline E. coli (36) & $0.52 \leq$ & $0.51 \leq$ & $0.47 \leq$ & - & - \\
\hline Enterobacter cloaceae (12E) & $0.52 \leq$ & $0.51 \leq$ & $0.47 \leq$ & - & - \\
\hline Flavobacterium branchiophilum (8I) & $0.52 \leq$ & $0.51 \leq$ & $0.47 \leq$ & - & - \\
\hline Klebsiella pneumoniae (11A) & 1.04 & 8.24 & 1.88 & - & - \\
\hline Pseudomonas staurtii (14D) & 4.16 & 4.12 & 3.76 & - & - \\
\hline Serratia fonticola (4B) & 4.16 & 8.24 & 1.88 & - & - \\
\hline Staphylococcus muscae (15D) & $0.52 \leq$ & 8.24 & $0.47 \leq$ & - & - \\
\hline
\end{tabular}

\subsection{Growth of Bacteria from Wastewater Samples Percentage Reduction Analysis}

The antibacterial activity of the essential oils Clove, Cinnamon, Oregano were tested directly against wastewater samples (AT-2, AT-4, AT-6, AT-8, DIG-1, DIG-2, Return Sludge) that include a diversity of bacterial cultures. The results revealed the inhibitory potential of all three essential oils against all seven wastewater samples on R2A agar plate to a varying degree (Table 4.7; Appendix M). clove oil reduced the mixed wastewater bacterial population to the largest degree, relative to other tested essential oils. in the anaerobic digesters, less against the bacteria in the aerated sludge samples and not at all to the return sludge sample. cinnamon oil showed a reduction of bacterial colonies consistently across all three types of samples. Similarly, oregano oil was 
effective at reducing the numbers of bacteria in all three types of samples. However, none of the essential oils at the concentrations (even lowest MICs) tested were able to completely inhibit all of the bacteria in the samples.

Table 4.7. The Percent Reduction in Colony Forming Unit of mixed Wastewater Bacterial Cultures due to Inhibition by Clove oil, Cinnimon oil and Oregano oil.

\begin{tabular}{|c|c|c|c|c|}
\hline \multirow{2}{*}{$\begin{array}{c}\text { Wastewater } \\
\text { Samples }\end{array}$} & \multicolumn{3}{|c|}{ Mixed Culture Percentage Reduction Analysis } & \multirow{2}{*}{$\begin{array}{l}\text { Control } \\
\text { WWTP } \\
\text { sample }\end{array}$} \\
\hline & $\begin{array}{l}\text { Clove } \\
\text { \% Reduction }\end{array}$ & $\begin{array}{l}\text { Cinnamon } \\
\text { \% Reduction }\end{array}$ & $\begin{array}{c}\text { Oregano } \\
\% \text { Reduction }\end{array}$ & \\
\hline AT-2 & $75 \%$ & $99 \%$ & $82.5 \%$ & $100 \%(660)$ \\
\hline AT-4 & $80 \%$ & $97.7 \%$ & $70 \%$ & $100 \%(308)$ \\
\hline AT-6 & $46 \%$ & $46 \%$ & $97 \%$ & $100 \%(295)$ \\
\hline AT-8 & $59.8 \%$ & $99.7 \%$ & $94.7 \%$ & $100 \%(430)$ \\
\hline DIG-1 & $78.1 \%$ & $84 \%$ & $87.7 \%$ & $100 \%(345)$ \\
\hline DIG-2 & $94.2 \%$ & $96.4 \%$ & $88.9 \%$ & $100 \%(267)$ \\
\hline $\begin{array}{l}\text { Return } \\
\text { Sludge }\end{array}$ & $0 \%$ & $82.7 \%$ & $75.35 \%$ & $100 \%(920)$ \\
\hline
\end{tabular}

\footnotetext{
${ }^{5} 100 \mathrm{ul}$ of raw wastewater sample mixed with $100 \mathrm{ul}$ of distilled water.
} 


\section{CHAPTER FIVE}

\section{DISCUSSION}

\subsection{Kirby-Bauer Disc Diffusion Assay}

In this study, the main objective was to determine the effectiveness of essential oils against wastewater bacteria. This study is the first to determine the effectiveness of essential oils against wastewater bacteria.

\subsubsection{Clove oil}

Previous studies have shown that clove oil can be quite inhibitory against bacterial strains by employing Kirby-Bauer disc diffusion assay. Moreira et al. (2005) reported that clove essential oil had strong bactericidal and bacteriostatic action against E. coli (Babu et al. 2011) further reported extreme sensitivity of $E$. coli to clove with zones of inhibition ranging from $21 \mathrm{~mm}$ to $61 \mathrm{~mm}$ by employing disc diffusion method with Muller-Hinton agar. (Burt et al. 2002) who reported clove being antibacterial against $E$. coli 0157: $H 7$ with a zone of inhibition halos $15.7 \mathrm{~mm}$. In the case of Staphylococcus aureus (Babu et al. 2011) who reported zone of inhibition halos $25 \mathrm{~mm}$, I found zone of inhibition halos of greater than 32.5. Further Aeromonas hydrophilla (Deans et al. 1987) reported zone of inhibition halos $16.5 \mathrm{~mm}$ while in this study zone of inhibition were found to be greater than $20 \mathrm{~mm}$. Deans et al. (1987) also reported zone of inhibition of $7 \mathrm{~mm}$ for Klebsiella pneumonii whereas this study recorded zone of inhibition greater than $23 \mathrm{~mm}$. The difference in results can be attributed to the fact all above reported experiments had used different essential oil concentrations and different growth media so it is not possible to compare results of current study with reported results in literature. However, this was the first study to examine the effect of essentail oils on Pseudomonas fluorescence, Stenotrophomonas maltophilies (2), Pseudomonas poa, Pseudomonas putida, Acinetobacter baumanii, Pseudomonas staurtii, Serratia fonticola, Staphylococcus muscae, Enterobacter cloaceae, Flavobacterium brachiophillum, and Acinetobacter bouretii and therefore this study adds to the existing information in the literautre.

\subsubsection{Cinnamon oil}

The previous studies based on Kirby-Bauer disc diffusion assay of cinnamon oil without added stabilizers (Prabuseenivasan. 2006) reported that cinnamon oil could be a of antibacterial agent based on zone of inhibition from 16.2 to $29.8 \mathrm{~mm}$ for E.coli, Staphylococcus aureus, Klebsiella 
pneumonii whereas this study found zones of inhibition halos between 19 and 36. Further, Silveria et al. (2012) reported a zone of inhibition of $17.4 \mathrm{~mm}$ and $11.5 \mathrm{~mm}$ against Staphylococcus aureus and E.coli respectively, whereas this study reported zone of inhibition from $27.5 \mathrm{~mm}$ to greater than $36 \mathrm{~mm}$. Zhang et al. 2016 who reported that cinnamon oil produced significant result against gram positive, and gram-negative bacteria and it exhibited good potential for application in food products, based on zones of inhibition of 19.2 to $28.7 \mathrm{~mm}$, whereas this study reported a zone of inhibition from $27.5 \mathrm{~mm}$ to greater than $36 \mathrm{~mm}$ against Staphylococcus aureus and E.coli. The difference in results can be attributed to the fact all above reported experiments had used different essential oil concentrations and different growth media so it is not possible to compare results of current study with reported results in literature. To the best of my knowledge the literature is silent on the effectiveness of cinnamon oil against bacteria in the species, Pseudomonas fluorescence, Stenotrophomonas maltophilies (2), Pseudomonas poa, Pseudomonas putida, Acinetobacter baumanii, Pseudomonas staurtii, Serratia fonticola, Staphylococcus muscae, Enterobacter cloaceae, Flavobacterium brachiophillum, and Acinetobacter bouretii.

\subsubsection{Oregano oil}

The previous studies based on disc diffusion assay of oregano oil (Burt et al. 2003) reported oregano oil zones of inhibition of $24.3 \mathrm{~mm}$ against E.coli whereas this study recorded zone of inhibition between $16 \mathrm{~mm}$ and $25 \mathrm{~mm}$, Marira et al. (2010) reported oregano oil zones of inhibition of $32 \mathrm{~mm}, 26 \mathrm{~mm}, 35 \mathrm{~mm}$ against Staphylococcus aureus, E.coli and Enterobacter cloceae whereas this study recorded zones of inhibition halos from 16 to greater than $40.5 \mathrm{~mm}$. Similarly Mith et al. (2014) reported oregano oil zones of inhibition of $15.9 \mathrm{~mm}$, and $15.6 \mathrm{~mm}$ against Pseudomonas flourescence, E.coli whereas this study reported zones of inhibition between $16 \mathrm{~mm}$ and $20 \mathrm{~mm}$. (Moreira et al. 2005) reported zones of inhibition of 10-12 mm, against different strains of E.coli whereas this study found zone of inhibition from 16 to $25 \mathrm{~mm}$. Dobre et al. (2011) reported zones of inhibition of $43.5 \mathrm{~mm}$ against Staphylococcus aureaus whereas I recorded zones of inhibition of $40.5 \mathrm{~mm}$. Rusenova et al. (2009) reported zone of inhibition of $17.7 \mathrm{~mm}, 35 \mathrm{~mm}$, $29.3 \mathrm{~mm}$ against Staphylococcus aureus, E.coli, Klebsiella pneumonii whereas this study recorded zone of inhibition of $40.5 \mathrm{~mm}, 16 \mathrm{~mm}$ and $22 \mathrm{~mm}$. The difference in results can be attributed to the fact that all above reported experiments had used different essential oil concentrations and 
different growth media so it is not possible to compare results of current study with reported results in literature. To the best of my knowledge, the literature is silent on the effectiveness of oregnao against Stenotrophomonas maltophilies, Pseudomonas poa, Pseudomonas putida, Acinetobacter baumanii, Pseudomonas staurtii, Serratia fonticola, Staphylococcus muscae, Flavobacterium brachiophillum, and Acinetobacter bouretii.

\subsubsection{Tea tree oil}

Previous studies (Rusenova et al. 2009) have reported teatree oil producing zones of inhibition of $27 \mathrm{~mm}$ against Staphylococcus aureus whereas this study reported zones of inhibition of $22 \mathrm{~mm}$ Rusenova et al. (2009) and Moreira et al. (2005) reported that tea tree oil produced zones of inhibition between $26 \mathrm{~mm}$, and $32 \mathrm{~mm}$ against E.coli whereas this study reported zones of inhibition of $14.5 \mathrm{~mm}$. The difference in results can be attributed to the fact all above reported experiments had used different essential oil concentrations and different growth media so it is not possible to compare results of current study with reported results in literature. Whereas to the best of my knowledge literature is silent in case of Stenotrophomonas maltophilies (2), Pseudomonas poa, Pseudomonas putida, Acinetobacter baumanii. This study showed that tea tree oil was inhibitory to some of the bacteria but not to all of them. This additional information adds the dispository of information about the usefulness of this essential oli in antibacterial inhibition

\subsubsection{Fennel oil}

The previous studies based on disc diffusion assay (Silveria et al. 2012) reported fennel oil zones of inhibition of $12.1 \mathrm{~mm}$, and $11.1 \mathrm{~mm}$ against Staphylococcus aureus, E. coli, whereas this study reported zones of inhibition of $24 \mathrm{~mm}$ and $18 \mathrm{~mm}$ respectively. Similarly, Deans et al. (1987) reported fennel oil zones of inhibition between $0 \mathrm{~mm}$, and $7.5 \mathrm{~mm}$ for E. coli, and Staphylococcus aureus and Diao et al. (2014) who reported zones of inhibition of $19.1 \mathrm{~mm}$ against $E$. coli. The difference in results can be attributed to the fact all above reported experiments had used different essential oil concentrations and different growth media so it is not possible to compare results of current study with reported results in literature. To the best of my knowledge literature is silent in case of Stenotrophomonas maltophilies, Pseudomonas poa, Pseudomonas putida, and Acinetobacter baumani. Overall Fennel oil did not exhibit strong antibacterial activity againsts the selected bacteria and therefroe was not included in further testing. 


\subsubsection{Wintergreen oil}

The previous studies based on disc diffusion assay (Prabuseenivasan 2006) reported zones of inhibition between $0 \mathrm{~mm}$, and $8.9 \mathrm{~mm}$ for Staphylococcus aureus and E. coli, whereas this study reported zones of inhibition between 14.9 and $27 \mathrm{~mm}$. The difference in results can be attributed to the fact all above reported experiments had used different essential oil concentrations and different growth media so it is not possible to compare results of current study with reported results in literature. Whereas to the best of my knowledge literature is silent in case of Stenotrophomonas maltophilia (2), Pseudomonas poae, Pseudomonas putida, and Acinetobacter baumanii.

\subsection{Minimum Inhibitory Concentration Assay}

The three essential oils (clove, cinnamon and oregano), which showed comparatively greater inhibitory activity during preliminary screening by employing disc diffusion assay, were selected for determination of the minimum inhibitory concentration (MIC) using broth tube dilution method.

\subsubsection{MIC of clove oil}

The literature suggested that clove essential oil at different concentration was inhibitory against different bacterial strains. Clove essential oil was able to reduce the bacterial population completely at or below MIC value of $5000 \mathrm{mg} / \mathrm{L}$ level for Escherichia coli, Staphylococcus aureus, Bacillus cereus, Yersinia enterocolitica (Siddiqua et al. 2014). In another study, (Stephani de Rapper et al. 2013) reported MIC values against Staphylococcus aureus and Pseudomonas aeruginosa of $1.5 \mathrm{mg} / \mathrm{ml}$. Similarly, Burt et al. (2003) reported a MIC value of $0.4-2.5 \mathrm{ul} / \mathrm{ml}$ each based on microdilution assay for clove essential oil against food isolated pathogens such as E.coli and Staphylococcus aureus. It was also reported that MICs against Klebsiella pneumoniae and E.coli were $>6.4 \mathrm{mg} / \mathrm{ml}$ and $>1.6 \mathrm{mg} / \mathrm{ml}$ respectively (Prabuseenvasan et al. 2006). Moreira et al. (2005) reported a MIC value of clove essential oil against E.coli ATCC 25158 of $0.25 \mathrm{ml} / 100 \mathrm{ml}$. This study found the MIC of the clove essential oil to be $0.52 \mathrm{mg} / \mathrm{ml}$ against E.coli, Staphylococcus muscae, Enterobacter cloaceae, Acinetobacter baumanii and Flavobacterium branchiophilum. 
The MIC concentration was $1.04 \mathrm{mg} / \mathrm{ml}$ against Klebsiella pneumoniae, $2.08 \mathrm{mg} / \mathrm{ml}$ against Aeromonas hydrophila, Acinetobacter bouretii, and $4.16 \mathrm{mg} / \mathrm{ml}$ against Pseudomonas staurtii, and Serratia fonticola.The MIC in this study was found to be in the same range as other studies, although it demonstrated that different bacteria were susceptibile to varying concnetrations of the essential oil.

\subsubsection{MIC of cinnamon oil}

The literature suggested that cinnamon oil at different concentration was inhibitory against bacteria isolated from different sources. In one paper, cinnamon essential oil showed significant inhibition with a MIC value of $0.125 \mathrm{ul} / \mathrm{ml}$ and an MBC (Minimum Bactericidal Concentration) value of $0.25 \mathrm{ul} / \mathrm{ml}$ against all five bacteria tested except Pseudomonas fluorescence that remained resistant against cinnamon at $\mathrm{MIC} / \mathrm{MBC}$ value $1 \mathrm{ul} / \mathrm{ml}$. According to another paper, the MIC of cinnamon essential oil against Klebsiella pneumonii and E.coli was $3.2 \mathrm{mg} / \mathrm{ml}$, and $>1.6 \mathrm{mg} / \mathrm{ml}$ respectively (Prabuseenvasan et al. 2006). Similarly, another paper has reported a MIC value of $5 \mathrm{mg} / \mathrm{ml}$ of cinnamon essential oil against E.coli with broth microdilution assay (Silveria et al. 2012).

In this study cinnamon oil had a MIC of $0.51 \mathrm{mg} / \mathrm{ml}$ against E.coli, Enterobacter cloaceae, Acinetobacter baumanii, Flavobacterium branchiophilum, a MIC of $1.03 \mathrm{mg} / \mathrm{ml}$ against Acinetobacter bouretii, a MIC of $4.12 \mathrm{mg} / \mathrm{ml}$ against Pseudomonas staurtii, Aeromonas hydrophila, and a MIC of $8.24 \mathrm{mg} / \mathrm{ml}$ against Klebsiella pneumoniae, Serratia fonticola, and Staphylococcus muscae.

\subsubsection{MIC of oregano oil}

The MIC of oregano essential oil against Aeromonas hydrophilla has been reported to be $2.5 \mathrm{ul} / \mathrm{ml}$ when the broth microdilution assay was employed (Azeredo et al. 2011). Similarly, another paper showed a MIC value of $0.5 \mathrm{ug} / \mathrm{ml}$ against Enterobacter cloacae by employing the broth microdilution assay (Sokovic et al. 2010). It was also reported in the literature that oregano essential oil possesses a MIC value of $1.8 \mathrm{ml} / 100 \mathrm{ml}$ against E.coli based on a broth microdilutrion assay (Moreira et al. 2005). The literature suggested that cinnamon oil at different concentration was inhibitory against bacteria isolated from different sources. This study found the MIC of oregano to be $0.47 \mathrm{mg} / \mathrm{ml}$ against E.coli, Staphylococcus muscae, Enterobacter cloaceae, 
Acinetobacter baumanii and Flavobacterium branchiophilum, to be $1.88 \mathrm{mg} / \mathrm{ml}$ against Klebsiella pneumoniae, Serratia fonticola, to be $3.76 \mathrm{mg} / \mathrm{ml}$ against Pseudomonas staurtii, Acinetobacter bouretii, to be $30.08 \mathrm{mg} / \mathrm{ml}$ against Aeromonas hydrophila. Although the MICs to the common bacteria were similar to that previously found, this was the first report of oregano's effect towards A. hydrophila, which appears to be quite resistant to the oil.

\subsection{Wastewater samples bacterial growth reduction percentage analysis}

In the literature, one study done by Moura et al. (2011) suggested a possible use of plant compounds and oils for the disinfection of water. Antibacterial activity of the M. oleifer flower preparations were evaluated and found to be active against Gram-negative and Gram-positive bacteria and impair the growth of microorganisms from environmental lake water. This study tested the antibacterial activity of six essentail oils. It was found that three of the essential oils, clove, cinnamon, and oregano were effective against seven different wastewater mixture samples including both aerated sludge (AT-2, AT-4, AT-6, AT-8), anaerobic digesters (DIG-1, DIG-2) and Return Sludge (RS) samples. 


\section{Conclusion}

This study opens a new window to essential "oils" antibacterial activity against municipal wastewater bacteria. The research on antibacterial activity of clove, cinnamon and oregano oil did not only confirm their antibacterial activity but also fill a void in scientific literature. This study aimed to identify antibacterial activity of these essential oils against wide array of municipal wastewater isolated bacteria and muncipal wastewater samples augments objectives of the research project. None of the oils completely inhibited bacteria growth in the samples; however, all the oils had a significant effect on both the aerobic (aerated sludge samples) and anaerobic (digester samples) bacterial population. The inhibition test performed at the lowest MIC was found to inhibit the individual strains and therefore higher concentrations may produce even further reductions in bacterial growth. Finally, the use of essential oils in conjunction with current chlorine treatment may improve the ability to eliminate all bacteria from water samples. On the other hand, the use of an essential oil treatment may allow a reduction in the chlorine usage and consequent reduction in the production of disinfection byproducts. 


\section{Future Study}

- This study is limited in scope as only bacteria isolated from wastewater were tested against these essential oils, but a broader investigation should include enteric bacteria such Compylobacter jejuni, Leptospira spirochete enteric viruses, the fungus Aspergillus, the protozoans Giardia and Cryptosporidium, and the tapeworm Hymenolepis respectively.

- Plant essential oils are screened and quantified for their antimicrobial activity, but so far their application as a disinfectant in the water reuse system have not been explored extensively (Winward et al. 2008). Based on these findings the application of plant essential oils in foodborne, food spoilage opens a new window towards the water, wastewater and water reuse disinfection potential that needs to be explored fully by further study.

- Electron microscopic analysis of bacterial strains inhibited by the activity of essential oils would help in understanding the mode of action of effective essential oils against bacteria. 


\section{APPENDIX A}

Preliminary Screening results of the antibacterial potential of Syzygium aromaticum

(Clove), Cinnamomum zeylanicum (Cinnamon), Origanum vulgare (Oregano), Melaleuca

alternifolia (Tea tree), Foeniculum vulgare (Fennel), Gaultheria procumbens (Wintergreen) against bacterial pure cultres (Disc size 13mm).

\section{Bacteria}

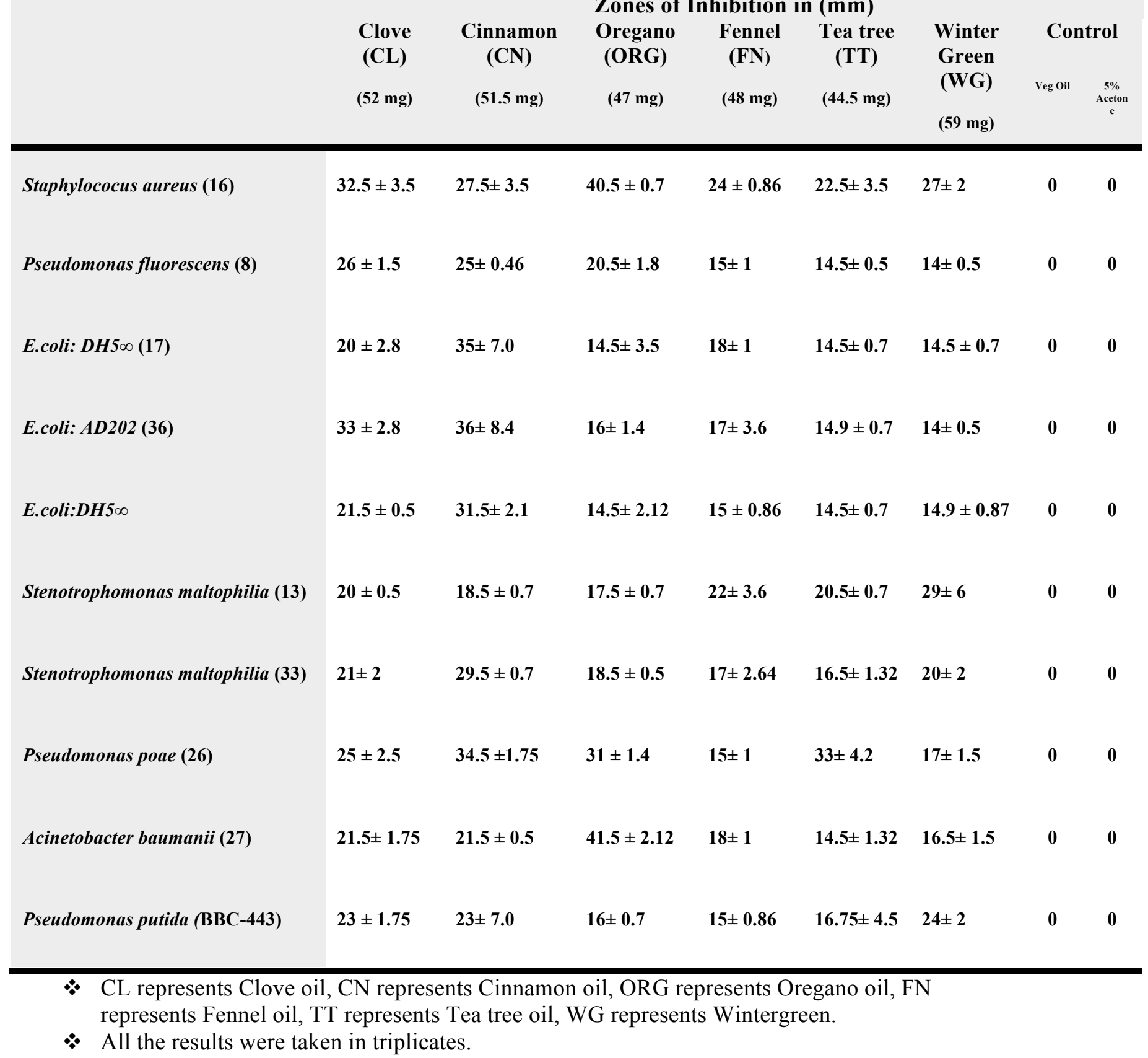




\section{APPENDIX B}

Preliminary Screening results of the antibacterial potential of Syzygium aromaticum (Clove), Cinnamomum zeylanicum (Cinnamon), Origanum vulgare(Oregano) against Wastewater isolated bacterial strains (Disc 6 mm).

\begin{tabular}{|c|c|c|c|c|c|}
\hline \multirow{3}{*}{ Bacteria } & \multirow{3}{*}{$\begin{array}{c}\text { Clove } \\
\text { (CL) } \\
(52 \mathrm{mg})\end{array}$} & \multicolumn{3}{|c|}{$\begin{array}{l}\text { Essential Oils Used } \\
\text { Zones of Inhibition in (mm) }\end{array}$} & \\
\hline & & \multirow{2}{*}{$\begin{array}{l}\text { Cinnamon } \\
\quad(\mathrm{CN}) \\
(51.5 \mathrm{mg})\end{array}$} & \multirow{2}{*}{$\begin{array}{l}\text { Oregano } \\
\text { (ORG) } \\
(47 \mathrm{mg})\end{array}$} & Control & \\
\hline & & & & Veg Oil & $\begin{array}{c}5 \% \\
\text { Acetone }\end{array}$ \\
\hline Pseudomonas staurtii (14D) & $22.6 \pm 3.5$ & $24.6 \pm 1.52$ & $22 \pm 4$ & 0 & 0 \\
\hline Aeromonas hydrophila (7A) & $20 \pm 2$ & $23.6 \pm 3.5$ & $31 \pm 1$ & 0 & 0 \\
\hline E. coli (36) & $31.6 \pm 1.5$ & $25 \pm 5$ & $25 \pm 5$ & 0 & 0 \\
\hline Klebsiella pneumoniae (11A) & $23 \pm 3$ & $19 \pm 1$ & $22 \pm 1$ & 0 & 0 \\
\hline Acinetobacter baumanii (2K) & $19.3 \pm 3.5$ & $26.3 \pm 3.2$ & $30 \pm 5.5$ & 0 & 0 \\
\hline Serratia fonticola (4B) & $27 \pm 2.6$ & $16 \pm 3.6$ & $25 \pm 5$ & 0 & 0 \\
\hline Staphylococcus muscae (15D) & $28 \pm 2$ & $25 \pm 5$ & $32 \pm 2$ & 0 & 0 \\
\hline Enterobacter cloaceae (12E) & $20.3 \pm 1.5$ & $18.6 \pm 3.5$ & $14 \pm 5.2$ & 0 & 0 \\
\hline Flavobacterium branchiophilum (8I) & $19.6 \pm 2.08$ & $33.3 \pm 7.6$ & $34.3 \pm 4.04$ & 0 & 0 \\
\hline Acinetobacter bouretii (10A) & $34 \pm 1.6$ & $27.3 \pm 3.7$ & $24 \pm 2$ & 0 & 0 \\
\hline
\end{tabular}


APPENDIX C
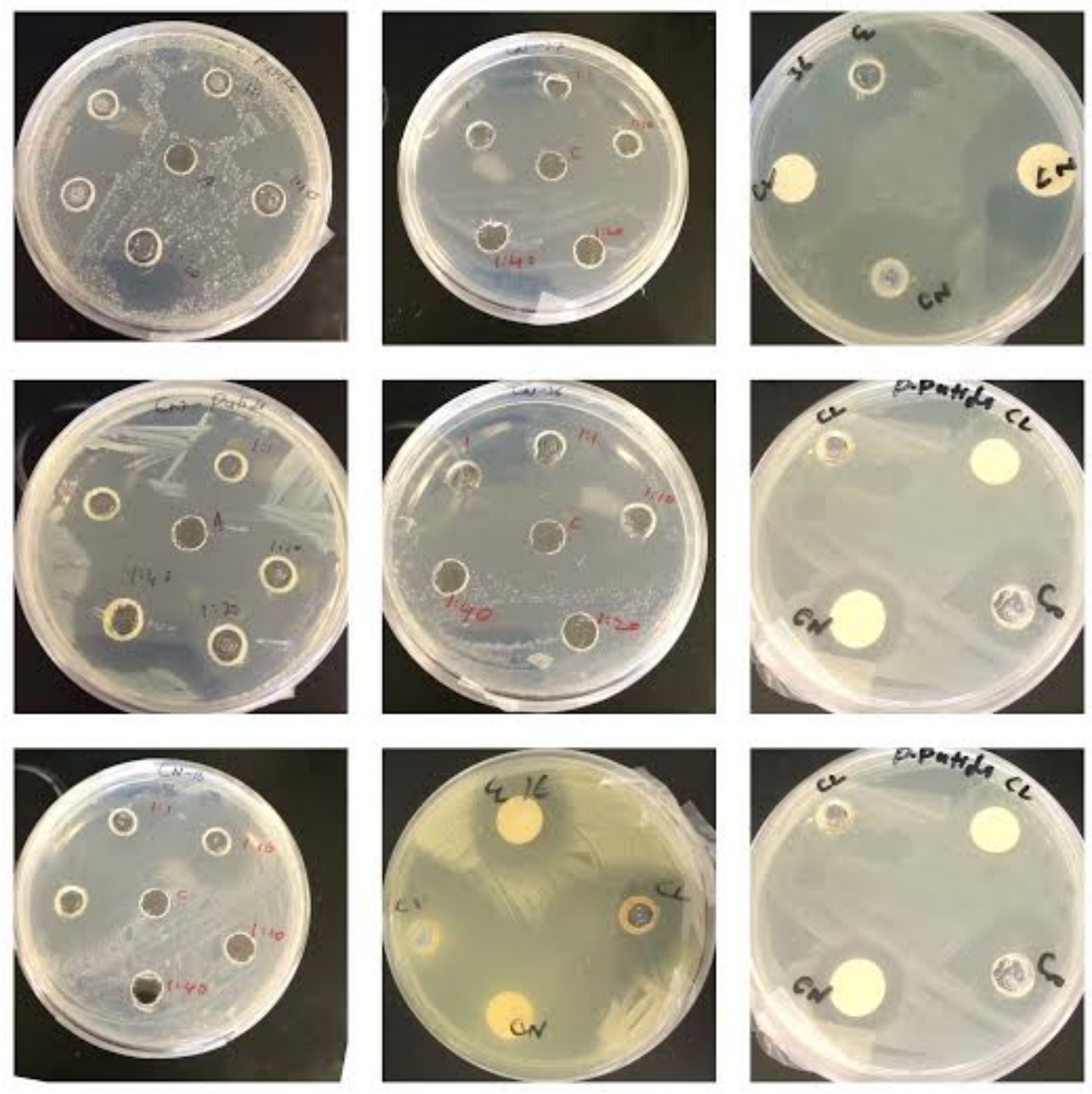

Plates Wild-type Bacterial Pure Cultures Sensitivity to Clove and Cinnamon Essential Oil. 
APPENDIX D
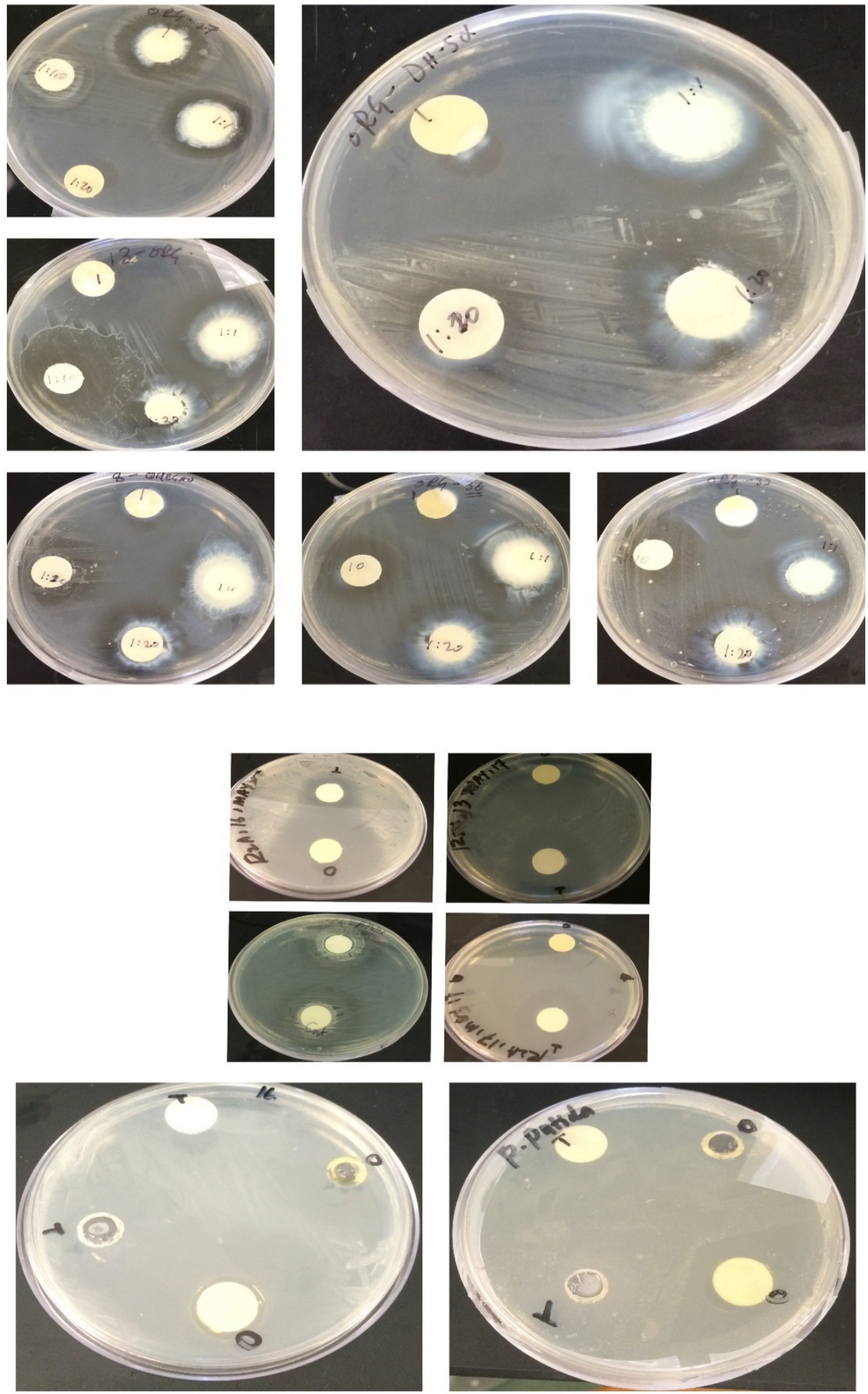

Plates Wild-type Bacterial Cultures Sensitivity to Oregano and Tea Tree Essential Oil. 


\section{APPENDIX E}
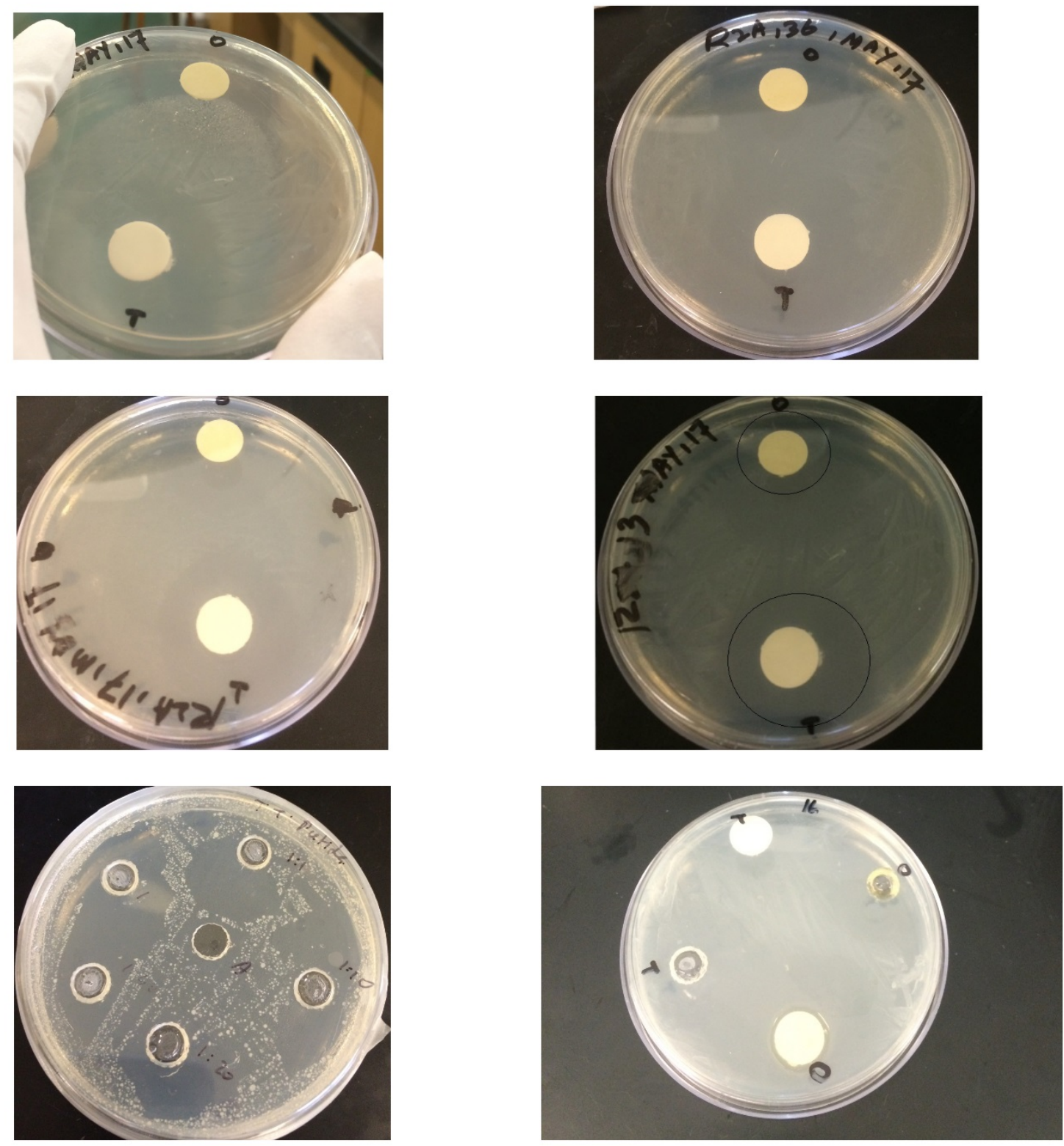

Plates Wild-type Bacterial Pure Cultures Sensitivity to Oregano and Tea Tree Essential Oil 


\section{APPENDIX F}
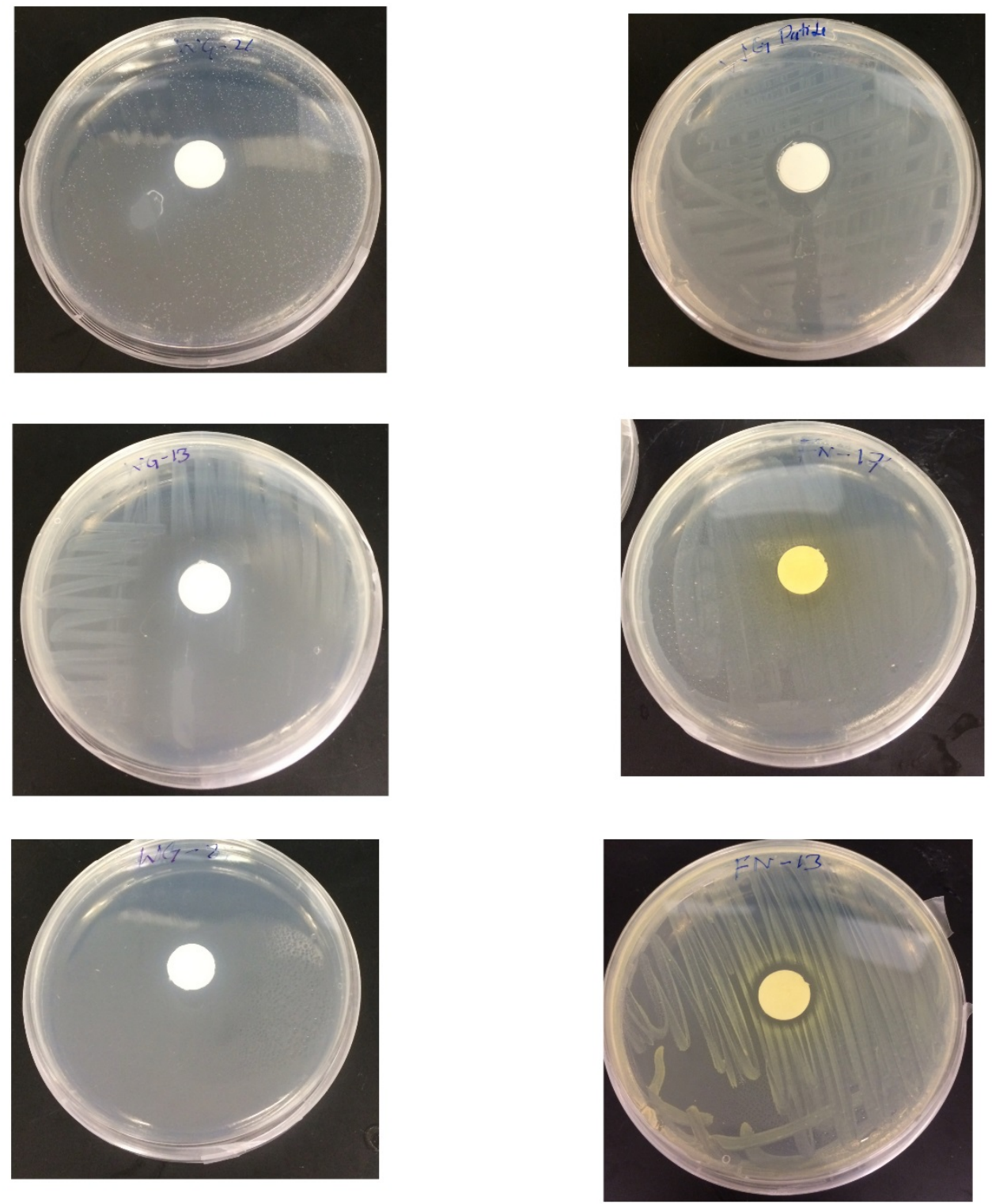

Plates Bacterial Pure Cultures Sensitivity to Fennel and Winter Green Essential Oil. 


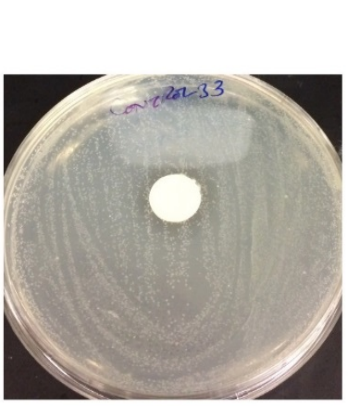

APPENDIX G
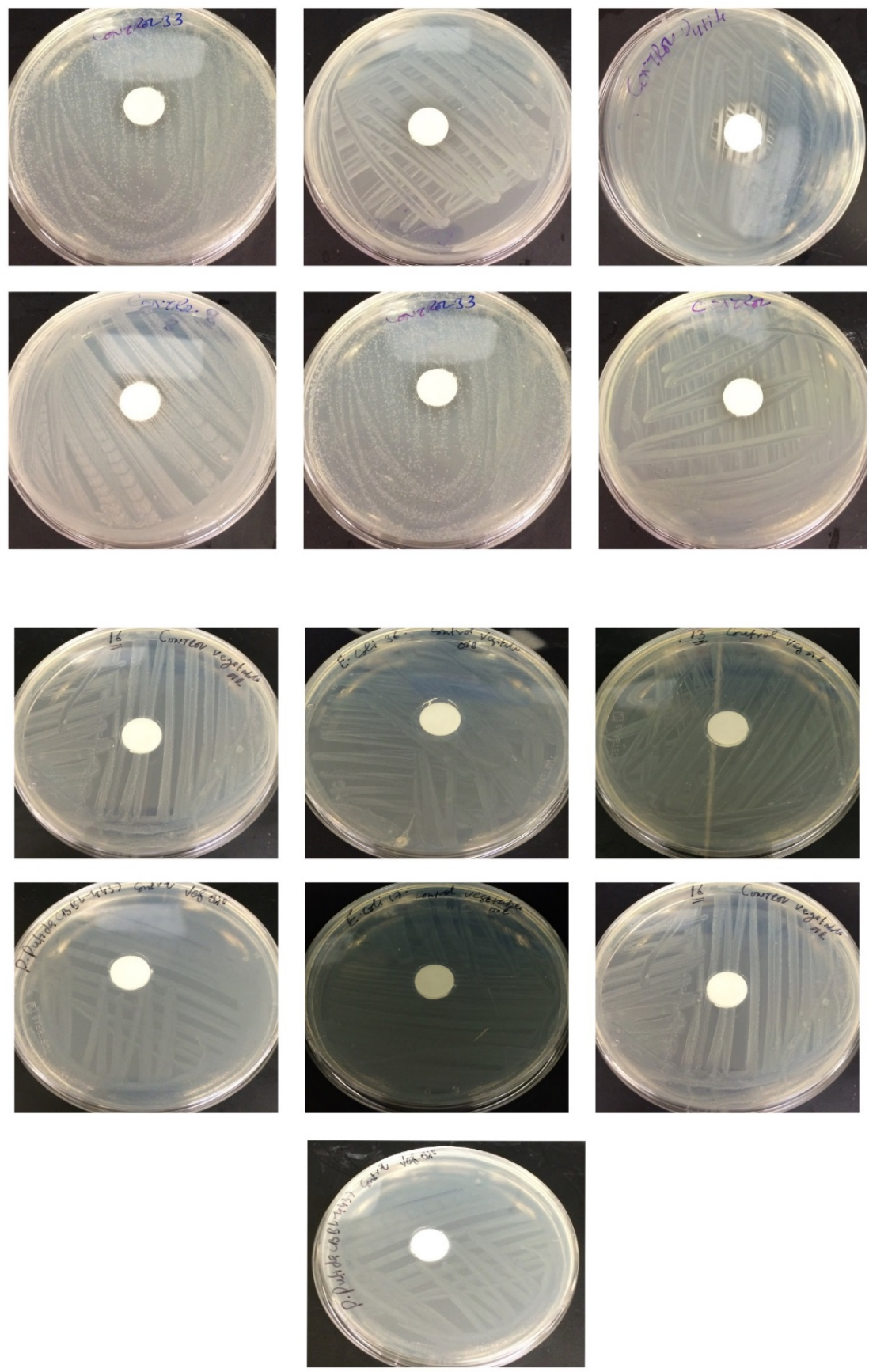

Plates Wild-type Bacterial Pure Cultures Sensitivity to Control Vegetable Oil and 5\% Acetone. 
APPENDIX H
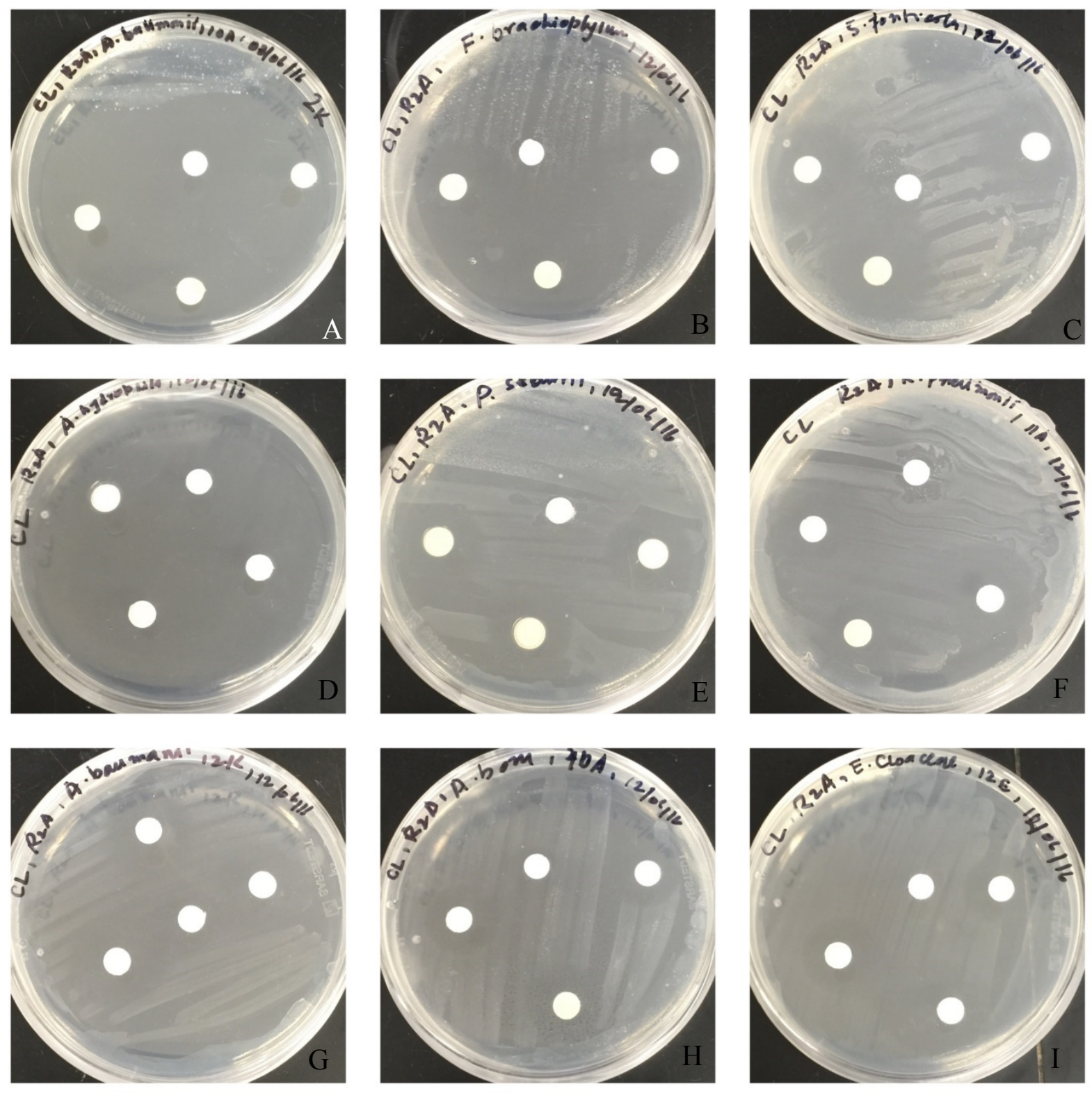

Plates Wastewater isolated Bacterial Sensitivity to Clove Essential Oil. 


\section{APPENDIX I}
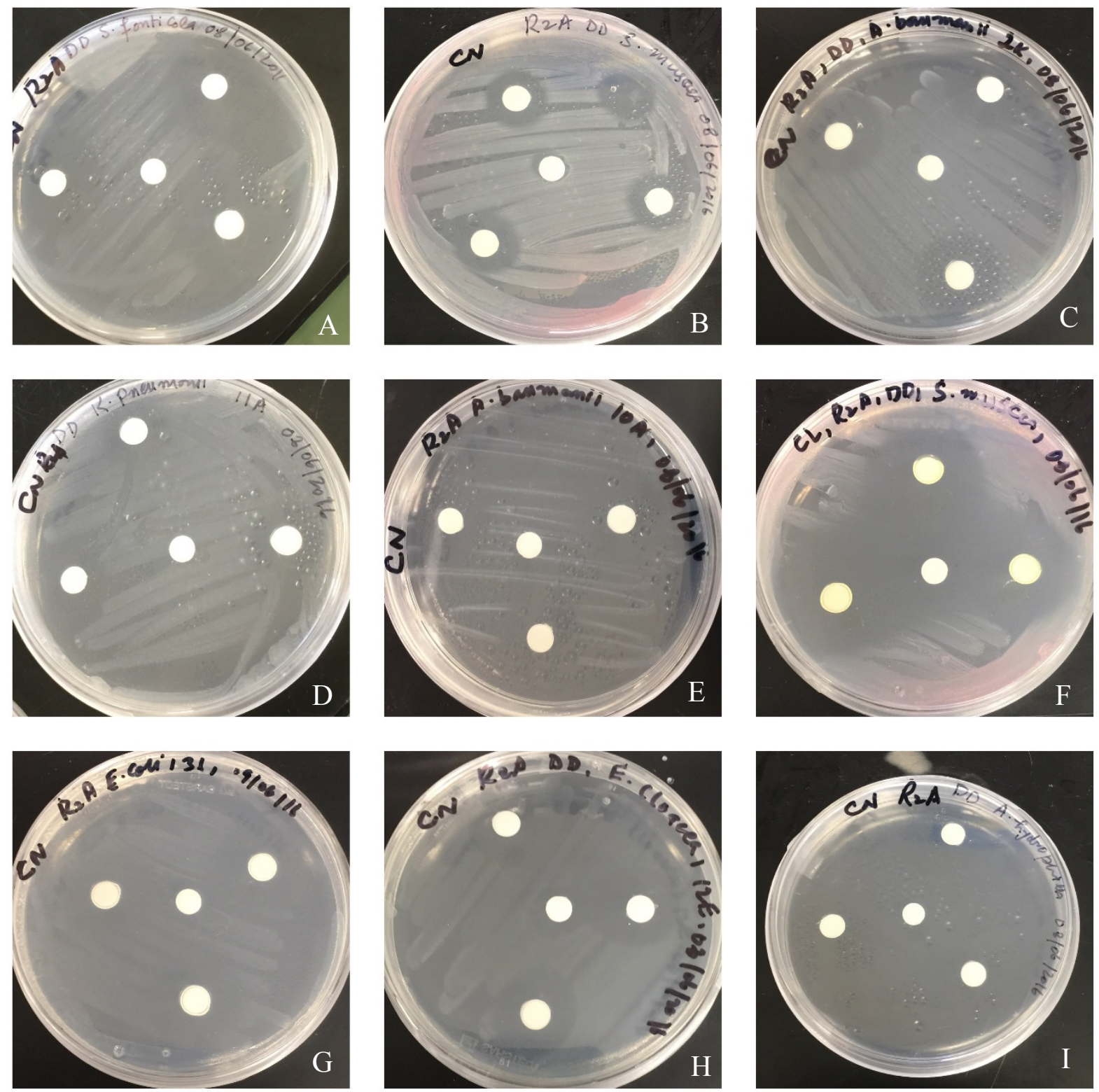

Plates Wastewater Isolated Bacterial Sensitivity to Clove Essential Oil. 
APPENDIX J
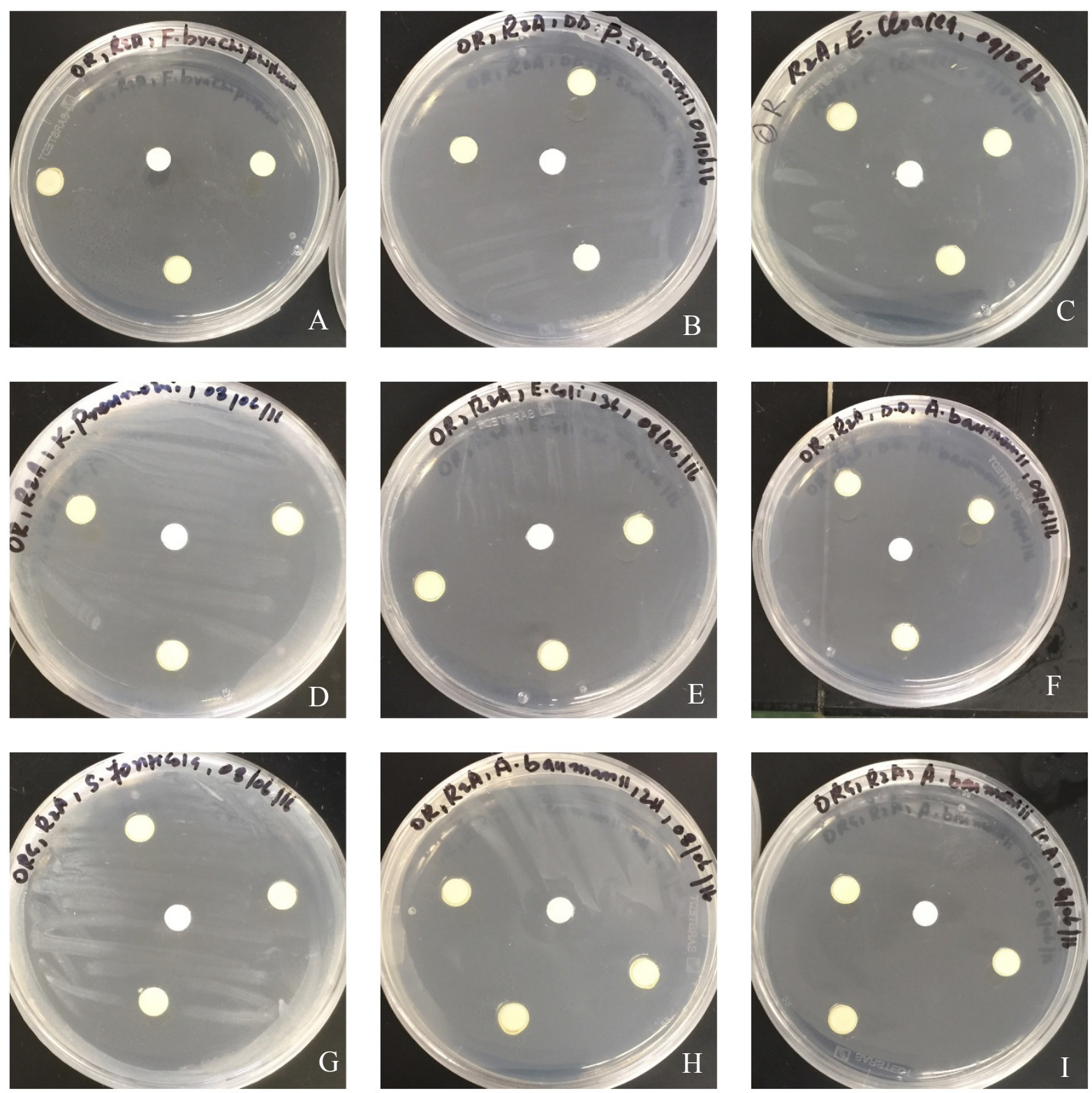

Plates Wastewater Isolated Bacterial Sensitivity to Clove Essential Oil. 
APPENDIX K

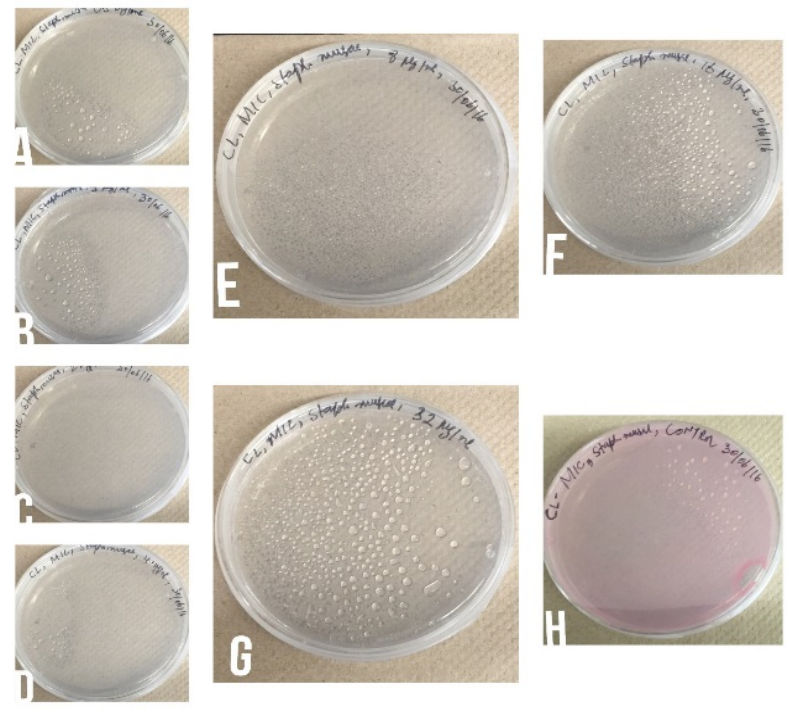

Plate Clove Essential Oil MIC (Minimum Inhibitory Concentration) against Staphylococcus muscae.
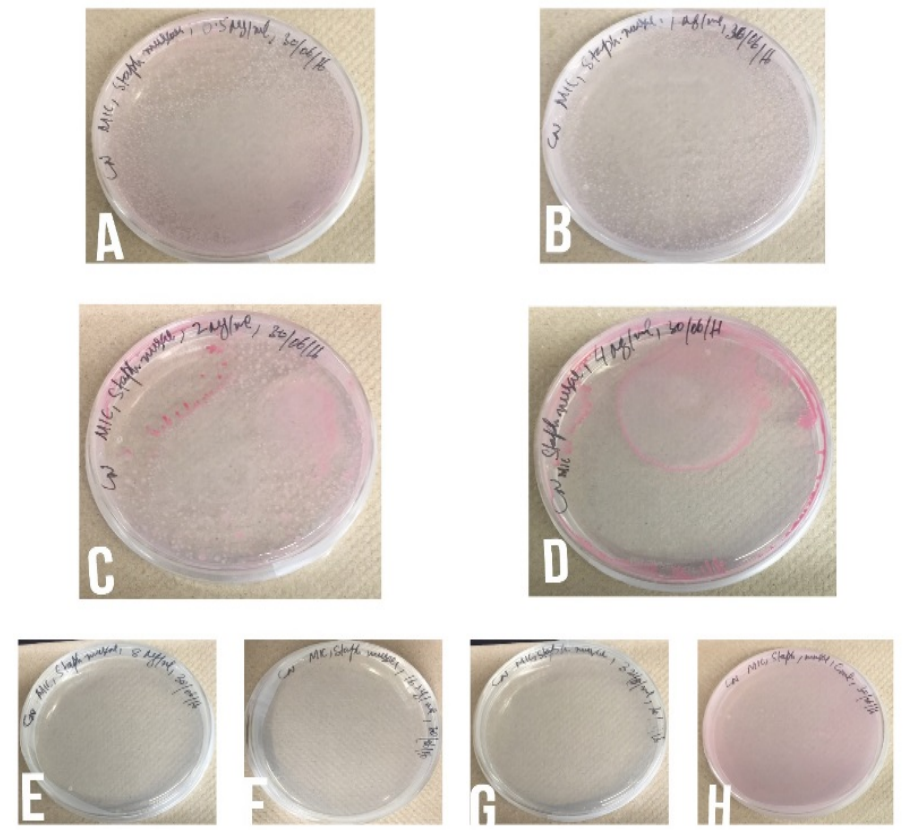

Plate Cinnamon Essential Oil MIC (Minimum Inhibitory Concentration) against Staphylococcus muscae. 

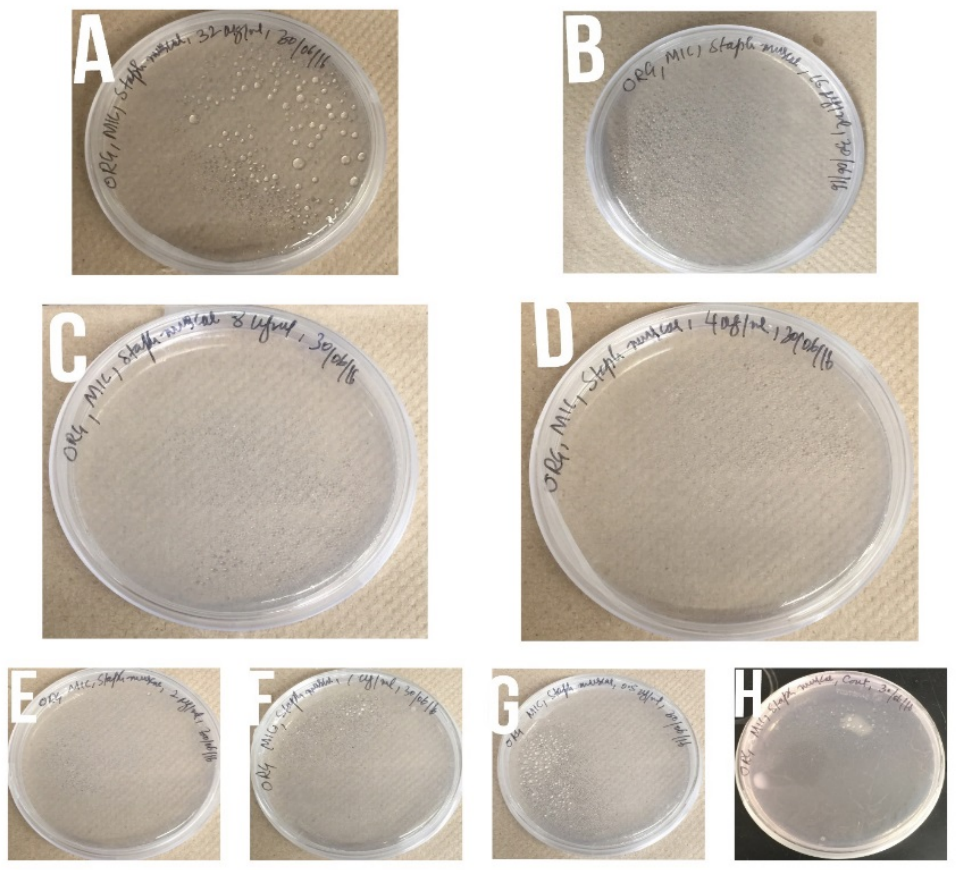

Plate Oregano Essential Oil MIC (Minimum Inhibitory Concentration) against

Staphylococcus muscae A-G $32 \mathrm{mg} / \mathrm{ml}, 16 \mathrm{mg} / \mathrm{ml}, 8 \mathrm{mg} / \mathrm{ml}, 4 \mathrm{mg} / \mathrm{ml}, 2 \mathrm{mg} / \mathrm{ml}, 1 \mathrm{mg} / \mathrm{ml}$, $0.5 \mathrm{mg} / \mathrm{ml}$, H Control. 


\section{APPENDIX L}
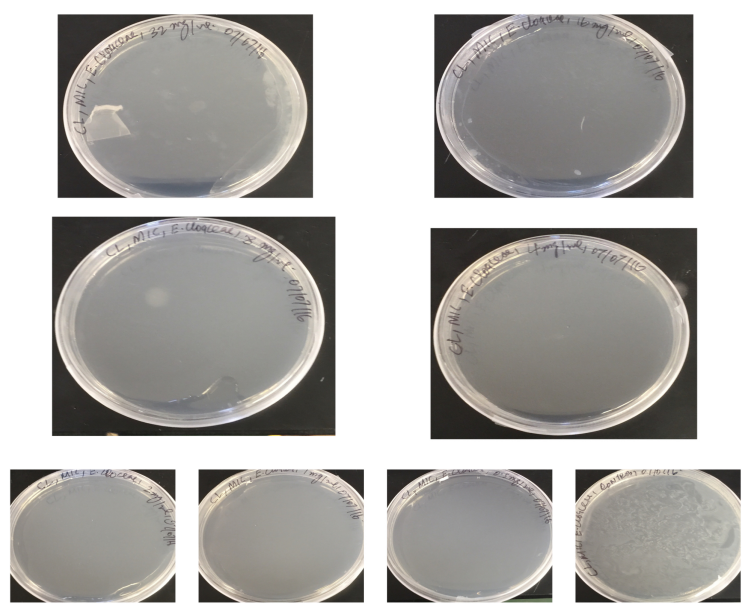

Plate Clove Essential Oil MIC (Minimum Inhibitory Concentration) against Enterobacter cloaceae.

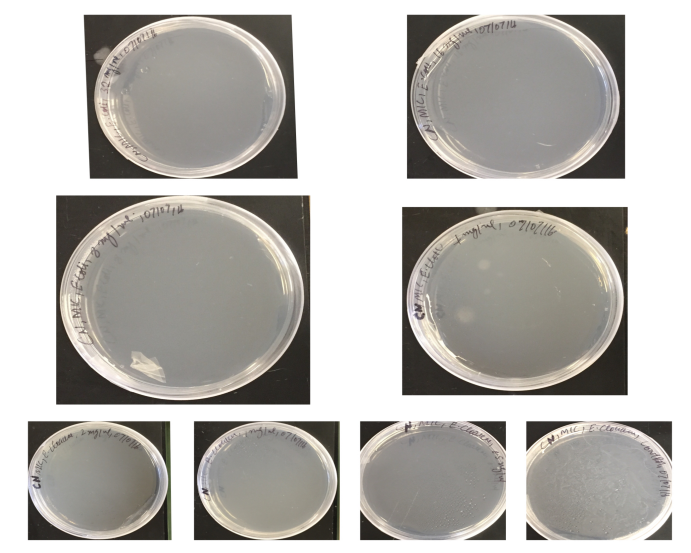

Plate Cinnamon Essential Oil MIC (Minimum Inhibitory Concentration) against Enterobacter cloaceae. 


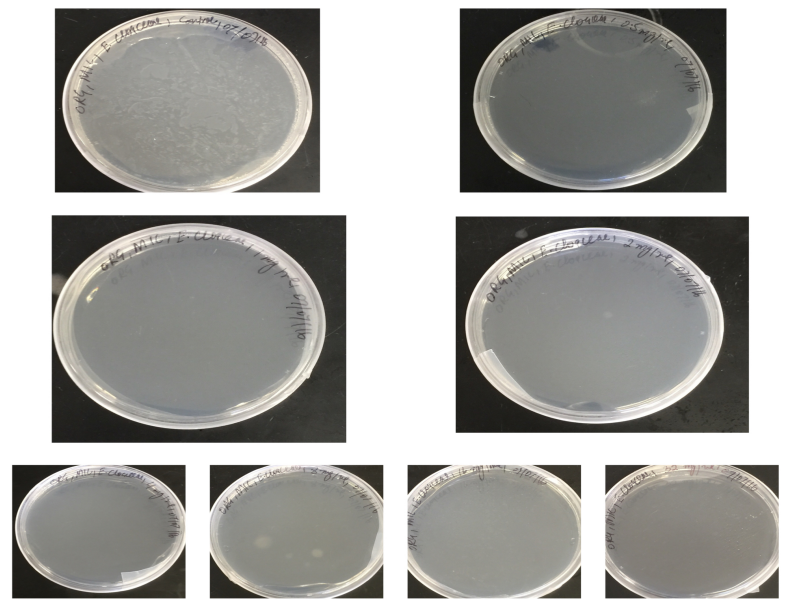

Plate Oregano Essential Oil MIC (Minimum Inhibitory Concentration) against Enterobacter cloaceae 

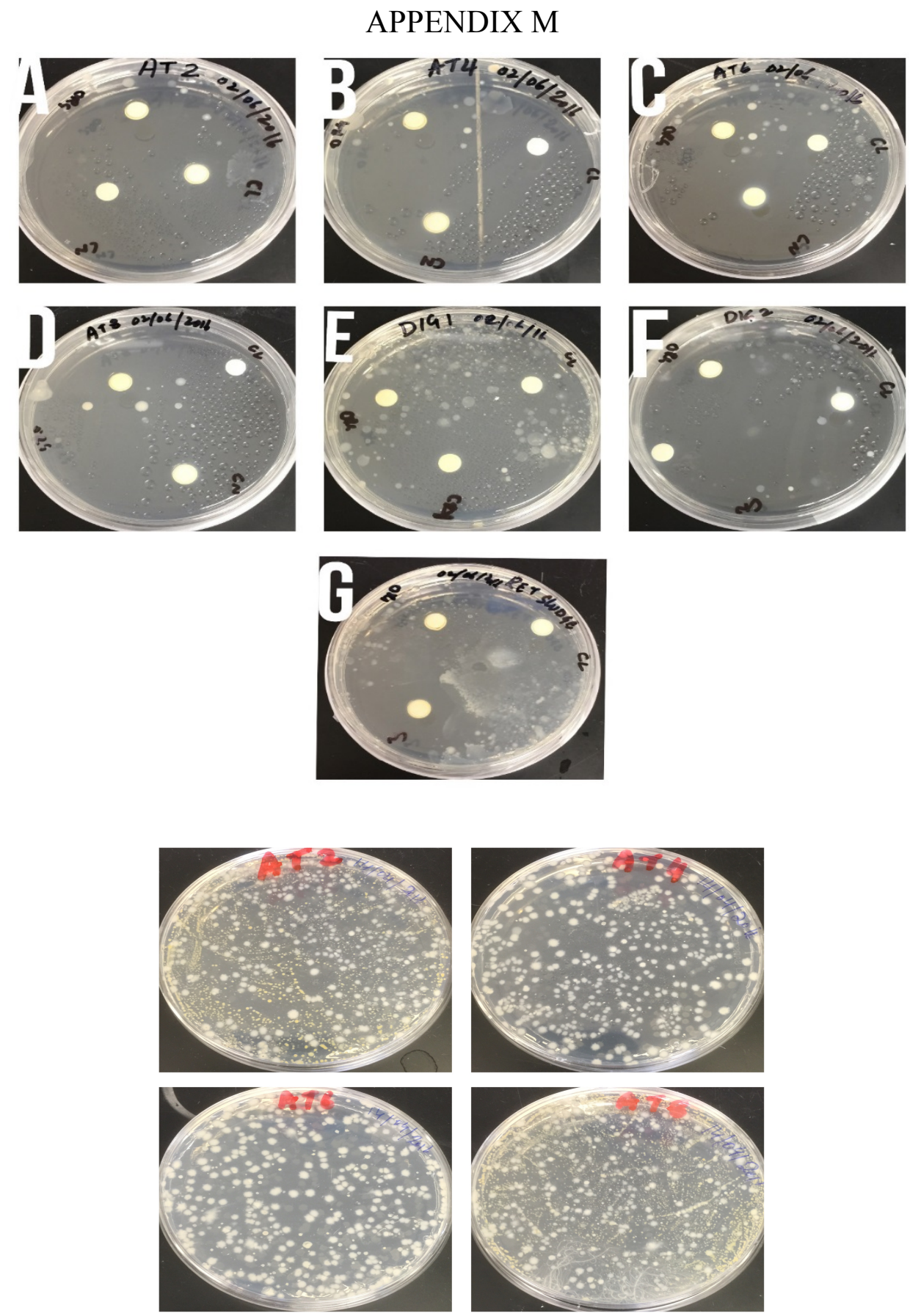

Plates Wastewater Mixture Bacterial Growth Inhibition A-D Aeration Tank (AT-2, AT-4, AT-6, AT-8), E-F Digester (DIG-1, DIG-2), G Return Sludge (RS) and Control. 


\section{REFERENCES}

Ali, B. Al-Wabel, N. A. Shams, S. Ahmad, A. Khan, S. A. and Anwar, F. 2015. Essential oils used in aromatherapy: A systemic review. Asian Pacific Journal of Tropical Biomedicine, 5:8:601-611.

Akthar, M. S. Degaga, B. and Azam, T. 2014. Antimicrobial activity of essential oils extracted from medicinal plants against the pathogenic microorganisms: a review. Issues in Biological Sciences and Pharmaceutical Research, 2:1:1-7.

Appendini, P. Hotchkiss, J. H. 2002. Review of antimicrobial food packaging. Innovative Food Science \& Emerging Technologies, 3:2:113-126.

Ashbolt, N. J. 2004 Risk analysis of drinking water microbial contamination versus disinfection by-products (DBPs). Toxicology, 198:1: 255-262.

Ayvaz, A. Sagdic, O. Karaborklu, S. and Ozturk, I. 2010. Insecticidal activity of the essential oils from different plants against three stored-product insects. Journal of insect science, $10: 1,21$.

Babu, A. J. Sundari, A. R. Indumathi, J. Srujan, R. V. N. and Sravanthi, M. 2011. Study on the antimicrobial activity and minimum inhibitory concentration of essential oils of spices. Vet. World, 4:7:311-316.

Bakkali, F. Averbeck, S. Averbeck, D. and Idaomar, M. 2008. Biological effects of essential oils-a review. Food and chemical toxicology, 46:2:446-475.

Baquero, F. Martínez, J. L. Cantón, R. 2008. Antibiotics and antibiotic resistance in water environments. Current opinion in biotechnology, 19:3:260-265. 
Bauer, A. W. Kirby, W. M. M. Sherris, J. C. and Turck, M. 1966. Antibiotic susceptibility testing by a standardized single disk method. American journal of clinical pathology, $45: 4: 493$.

Becerril, R., Nerín, C., and Gómez-Lus, R. 2012. Evaluation of bacterial resistance to essential oils and antibiotics after exposure to oregano and cinnamon essential oils. Foodborne pathogens and disease. 9:8:699-705.

Benchaar, C. Calsamiglia, S. Chaves, A. V. Fraser, G. R., Colombatto, D. McAllister, T. A. and Beauchemin, K. A. 2008. A review of plant-derived essential oils in ruminant nutrition and production. Animal Feed Science and Technology, 145:1:209-228.

Beuchat, L. R., and Golden, D. A. 1989. Antimicrobials occurring naturally in foods. Food technology (USA).

Bishop, C. D. 1995. Antiviral activity of the essential oil of Melaleuca alternifolia (Maiden amp; Betche) Cheel (tea tree) against Tobacco Mosaic Virus. Journal of Essential Oil Research. 7:6:641-644.

Bouhdid, S. Abrini, J. Zhiri, A. Espuny, M. J. Manresa, A. 2009. Investigation of functional and morphological changes in Pseudomonas aeruginosa and Staphylococcus aureus cells induced by Origanum compactum essential oil. Journal of applied microbiology, 106:5:15581568.

Brackman, G. Cos, P., Maes, L. Nelis, H. J. and Coenye, T. 2011. Quorum sensing inhibitors increase the susceptibility of bacterial biofilms to antibiotics in vitro and in vivo. Antimicrobial agents and chemotherapy, 55:6:2655-2661.

Brantner, A. and Grein, E. 1994. Antibacterial activity of plant extracts used externally in traditional medicine. Journal of Ethnopharmacology, 44:1:35-40. 
Brubaker, E. 2011. A Bridge Over Troubled Waters: Alternative Financing and Delivery of Water and Wastewater Services. CD Howe Institute Commentary.330.

Burt, S. A. and Reinders, R. D. 2003. Antibacterial activity of selected plant essential oils against Escherichia coli O157: H7. Letters in applied microbiology, 36:3:162-167.

Burt, S. 2004. Essential oils: their antibacterial properties and potential applications in foods - a review. International journal of food microbiology, 94:3, 223-253.

Burton, G. A. 2013. Assessing sediment toxicity: past, present, and future. Environmental Toxicology and Chemistry, 32:7:1438-1440.

Campiglia, E., Mancinelli, R., Cavalieri, A., and Caporali, F. 2007. Use of Essential Oils of Cinnamon, Lavender and Peppermint for Weed Control. Italian Journal of agronomy, $2: 2: 171-178$.

Caillet, S. Shareck, F. Lacroix, M. 2005. Effect of gamma radiation and oregano essential oil on murein and ATP concentration of Escherichia coli O157: H7. Journal of Food Protection ${ }^{\circledR}$, 68:12:2571-2579.

Canada Health 1995. A national survey of disinfection by products in Canadian drinking water

(95-EHD-197), Environmental Health Directorate, Ottawa, Ontario.

Canada Health 2015. Guidelines for Canadian Drinking Water Quality: Guideline Technical Document - pH. Water and Air Quality Bureau, Healthy Environments and Consumer Safety Branch, Health Canada, Ottawa, Ontario. (Catalogue No H144-28/2016E-PDF). 
Canada, Health 2008, Guidelines for Canadian Drinking Water Quality, Prepared by the Federal-Provincial-Territorial Committee on Health and the Environment. Print

Canada, Health 2011. Canadian drinking water guidelines. http://www.hc-sc.gc.ca/ewhsemt/water-eau/drink-potab/guide/index-eng.php.

Canada, Health 2014. Guidelines for Canadian Drinking Water Quality—Summary Table.

Water and Air Quality Bureau, Healthy Environments and Consumer Safety Branch, Health Canada, Ottawa, Ontario. Print

Canada, Health 2015. Drinking water advisories in First Nations Communities. Retrieved December 9, 2015, from www.hc-sc.gc.ca/fniah-spnia/promotion/public-publique/waterdwa-eau-eng.php.

Canada Statistics 2008. Canada: Essential Oil Imports and Exports. www.agr.gc.ca/resources/prod/doc/prod/psc-lcs/pdf/essential_en.pdf

Carson, C. F. Cookson, B. D. Farrelly, H. D. and Riley, T. V. 1995. Susceptibility of methicillin-resistant Staphylococcus aureus to the essential oil of Melaleuca alternifolia. Journal of Antimicrobial Chemotherapy, 35:3:421-424.

CBC 2015. Billions of liters of raw sewage, untreated waste water pouring into Canadian Waterways http://www.cbc.ca/news/politics/sewage-pollution-wastewater-cities$\underline{1.3889072}$

CEPA. 1999. Canadian Environmental Protection Act: Chlorinated Wastewater Effluents. 
Chemat, F. Vian, M. A. Cravotto, G. 2012. Green extraction of natural products: Concept and principles. International journal of molecular sciences, 13:7:8615-8627.

Chowdhury, S. Rodriguez, M. J. and Sadiq, R. 2011. Disinfection byproducts in Canadian provinces: associated cancer risks and medical expenses. Journal of hazardous materials, 187:1: 574-584.

Costa Batllori, P. Salado, S. Medel, P. and Asensio Bonin, J. 1999. Productos naturales de origen vegetal: una alternativa a los aditivos antimicrobianos en alimentación animal. Anaporc. Revista de Porcinocultura, 19:190:51-58.

Cosentino, S. Tuberoso, C. I. G. Pisano, B. Satta, M. L. Mascia, V., Arzedi, E. Palmas, F. 1999. In-vitro antimicrobial activity and chemical composition of Sardinian thymus essential oils. Letters in applied microbiology, 29:2:130-135.

City of Toronto 2010. Ashbridges Bay Treatment Plant Effluent Disinfection Class EA Study Report. www1.toronto.ca/city.../ashbridges_bay.../disinfection-ea-project-file.pdf

Cutter, C. N. 2000. Antimicrobial effect of herb extracts against Escherichia coli O157: H7, Listeria monocytogenes, and Salmonella typhimurium associated with beef. Journal of Food Protection ${ }^{\circledR}, 635,601-607$.

De Azeredo, G. A. Stamford, T. L. M. Nunes, P. C. Neto, N. J. G. De Oliveira, M. E. G. De Souza, E. L. 2011. Combined application of essential oils from Origanum vulgare L. and Rosmarinus officinalis L. to inhibit bacteria and autochthonous microflora associated with minimally processed vegetables. Food Research International. 44:5, 1541-1548.

De Silva, T. 1997. Industrial utilization of medicinal plants in developing countries. Rome: Medicinal plants for forest conservation and health care FAO, 34-44. 
de Rapper, S. Kamatou, G. Viljoen, A. and van Vuuren, S. 2013. The in vitro antimicrobial activity of Lavandula angustifolia essential oil in combination with other aromatherapeutic oils. Evidence-Based Complementary and Alternative Medicine.

Delaquis, P. J., and Mazza, G. 1995. Antimicrobial properties of isothiocyanates in food preservation. Food Technology, 49:11:73-84.

Dias, D. A. Urban, S. and Roessner, U. 2012. A historical overview of natural products in drug discovery. Metabolites, 2:2:303-336.

Djilani, A. and Dicko, A. 2012. The therapeutic benefits of essential oils. Nutrition, Well-Being and Health, 7:155-179.

Djeussi, D. E. Noumedem, J. A. Seukep, J. A. Fankam, A. G. Voukeng, I. K. Tankeo, S. B. Kuete, V. 2013. Antibacterial activities of selected edible plants extract against multidrug-resistant Gram-negative bacteria. BMC Complementary and Alternative Medicine, 13:164. http://doi.org/10.1186/1472-6882-13-164.

Dobre, A. A., Gagiu, V., and Petru, N. 2011. Antimicrobial activity of essential oils against food-borne bacteria evaluated by two preliminary methods. Rom Biotech Lett, 16:6, 119125 .

Dorman, H. J. D., and Deans, S. G. 2000. Antimicrobial agents from plants: antibacterial activity of plant volatile oils. Journal of applied microbiology, 88:2:308-316.

Edris, A. E. 2007. Pharmaceutical and therapeutic potentials of essential oils and their individual volatile constituents: a review. Phytotherapy Research, 21:4:308-323.

Epstein, P. R. Ford, T. E. Puccia, C.and Possas, C. D. A. 1994. Marine ecosystem health implications for public health. Annals of the New York Academy of Sciences, 740:1: $13-23$. 
Ericsson, H. M. and Sherris, J. C. 1971. Antibiotic sensitivity testing. Report of an international collaborative study. Acta Path. et Microb. Scandinavica, Suppl. 217.

Evans, W. C. 2009. Trease and Evans' pharmacognosy. Elsevier Health Sciences.

Environment and Climate Change Canada 2015. Examination report by independent experts on the technical and scientific information regarding the planned discharge of untreated wastewater effluent into the St. Lawrence by the City of Montréal October 30, 2015 https://www.ec.gc.ca/eau-water/default.asp?lang=En\&n=9FF2FE18-1

Environment and Climate Change Canada 2016. Wastewater system effluents regulation Enacted under the Fisheries Act https://www.ec.gc.ca/pollution/default.asp?lang=En\&n=072416B9-1

Fawell, J. and Nieuwenhuijsen, M. J. 2003. Contaminants in drinking water environmental pollution and health. British Medical Bulletin, 68:1:199-208.

FDA 2016. Substance Generally recognised as safe: essential oils, solvents, oleoresins and natural extractive.

Fent, K. Weston, A. A. and Caminada, D. 2006. Ecotoxicology of human pharmaceuticals. Aquatic toxicology, 76:2:122-159. 
Fernando, D. M. Tun, H. M. Poole, J. Patidar, R. Li, R., Mi, R. and Kumar, A. 2016.

Detection of Antibiotic Resistance Genes in Source and Drinking Water Samples from a First Nation Community in Canada. Applied and environmental microbiology, AEM00798.

Finnemore, H. 1926. The essential oils. Ernest Benn Limited.

Galvão, L. C. D. C. Furletti, V. F. Bersan, S. M. F. da Cunha, M. G. Ruiz, A. L. T. G. Carvalho, J. E. D. and Ikegaki, M. 2012. Antimicrobial activity of essential oils against Streptococcus mutants and their antiproliferative effects. Evidence-Based Complementary and Alternative Medicine.

Gaunt, L. F. Higgins, S. C. Hughes, J. F. 2005. Interaction of air ions and bactericidal vapours to control micro-organisms. Journal of applied microbiology, 99:6:1324-1329.

Gilbride, K. A. Lee, D. Y. and Beaudette, L. A. 2006. Molecular techniques in wastewater: understanding microbial communities, detecting pathogens, and real-time process control. Journal of microbiological methods, 66:1:1-20.

Goldman, P. 2001. Herbal medicines today and the roots of modern pharmacology. Annals of internal medicine, 135:8:1:594-600.

Gopal, K. Tripathy, S. S. Bersillon, J. L. and Dubey, S. P. 2007. Chlorination byproducts, their toxicodynamics and removal from drinking water. Journal of hazardous materials, 140:1:16.

Guenther, E. 1948. The Essential Oils, Vol. IV. The Essential Oils, Vol. IV.

Haagen-Smit, A. J. 1961. Essential Oils. Engineering and Science, 24:8:7-11.

Hammer, K. A. Carson, C. F. and Riley, T. V. 1999. Antimicrobial activity of essential oils and other plant extracts. Journal of applied microbiology, 86:6:985-990. 
Helt, C. 2012. Occurrence, fate, and mobility of antibiotic resistant bacteria and antibiotic resistance genes among microbial communities exposed to alternative wastewater treatment systems.

Helal, G. A. Sarhan, M. M. Abu Shahla, A. N. K. and Abou El-Khair, E. K. 2006. Antimicrobial activity of some essential oils against microorganisms deteriorating fruit juices. Mycobiology, 34:4:219-229.

Hili, P. Evans, C. S. Veness, R. G. 1997. Antimicrobial action of essential oils: the effect of dimethylsulphoxide on the activity of cinnamon oil. Letters in applied microbiology, 24:4: 269-275.

Hrudey, S. E. Payment, P. Huck, P. M. Gillham, R.W. and E.J, Hrudey. 2003 "A Fatal Waterborne Disease Epidemic in Walkerton, Ontario: Comparison with Other Waterborne Outbreaks in the Developed World." IWA Publishing 37:3 Print.

Hlavinek, P. 2009. Risk management of water supply and sanitation systems Springer.

Rasooli, I. 2007. Food preservation-a biopreservative approach. Food, 1:2:111-136.

Joy, P. P. Thomas, J. Mathew, S. and Skaria, B. P. 1998. Medicinal plants. Tropical Horticulture. 2:449-632.

Jorgensen, J. H. and Turnidge, J. D. 2015. Susceptibility test methods: dilution and disk diffusion methods. In Manual of Clinical Microbiology, Eleventh Edition (pp. 1253-1273). American Society of Microbiology.

Julian Davies and Dorothy Davies. 2010. "Origins and Evolution of Antibiotic Resistance." Microbiol Mol Biol Rev 74: 417-433. Print. 
Kavanagh .F, Analytical Microbiology. London: Academic press. 1963:125-141.

Khan, M. S. A. Zahin, M. Hasan, S. Husain, F. M. and Ahmad, I. 2009. Inhibition of quorum sensing regulated bacterial functions by plant essential oils with special reference to clove oil. Letters in applied microbiology, 49:3:354-360.

Lang, G.Buchbauer, G. 2012. A review on recent research results (2008-2010) on essential oils as antimicrobials and antifungals. A review. Flavour and Fragrance Journal, 27:1:13-39.

Lambert, R. J. W. Skandamis, P. N. Coote, P. J. Nychas, G. J. 2001. A study of the minimum inhibitory concentration and mode of action of oregano essential oil, thymol and carvacrol. Journal of applied microbiology, 91:3:453-462.

Lawrence, B. M. 2009. A preliminary report on the world production of some selected essential oils and countries. Perfumer \& Flavorist, 34:1:38-44.

Lawless, J. 2013. The Encyclopedia of essential oils: the complete guide to the use of aromatic oils in aromatherapy, herbalism, health, and wel being. Conari Press.

Leroi-Gourhan, A. 1975. The flowers found with Shanidar IV, a Neanderthal burial in Iraq. Science, 190:562-564.

Lietava, J. 1992. Medicinal plants in a Middle Paleolithic grave Shanidar IV, Journal of ethnopharmacology, 35:3:263-266.

Lis-Balchin, M. and Deans, S. G. 1997. Bioactivity of selected plant essential oils against Listeria monocytogenes. Journal of Applied Microbiology, 82:6:759-762.

Maiara C. Moura, Emmanuel V. Pontual, Francis S. Gomes, Thiago H. Napoleão, Patrícia M.G. Paiva, Luana C.B.B. Coelho and Haroudo S., Xavier 2011. Preparations of Moringa oleifera flowers to treat contaminated water. : Nova Science Publishers, Inc. 
Manabe, M. Kawamura, H. Yamashita, A. and Tokunaga, S. J. 1987. Colloid Interface Sci. 115:147.

Mendes, M. F. and Pessoa, F. L. 2010. Spices, Seasonings, and Essential Oils. Handbook of Fruit and Vegetable Flavors, 1023.

Michael, I., Rizzo, L. McArdell, C. S., Manaia, C. M., Merlin, C., Schwartz, T. and FattaKassinos, D. 2013. Urban wastewater treatment plants as hotspots for the release of antibiotics in the environment: a review. Water research, 47:3:957-995.

Mith, H. Duré, R. Delcenserie, V. Zhiri, A. Daube, G. and Clinquart, A. 2014. Antimicrobial activities of commercial essential oils and their components against foodborne pathogens and food spoilage bacteria. Food science \& nutrition, 2:4:403-416.

Minister of Supply and Services, Canada 1993. Canadian Environmental Protection Act, Chlorinated Wastewater Effluents, Catalog No. 40- 215/12E, ISBN 0-662-20470-0 p.21

Mittal, M. Gupta, N., Parashar, P. Mehra, V. and Khatri, M. 2014. Phytochemical evaluation and pharmacological activity of Syzygium aromaticum: a comprehensive review. International Journal of Pharmacy and Pharmaceutical Sciences, 6:8:67-72.

MOE. 2008. Ontario Design Guidelines for Sewage Works. ISBN 978-1-42498438-1

Mohan, T. 2011. Evaluation of LD50 Value of the Phytopesticide Piperidine on the Adult Male Insect Odontopus varicornis (Heteroptera: Pyrrhocoridae). International Journal of Pharmaceutical \& Biological Archive, 2:6. 
Moldovan, Z. 2006. Occurrences of pharmaceutical and personal care products as micropollutants in rivers from Romania. Chemosphere, 64:11:1808-1817.

Monzote, L. García, M. Scull, R. Cuellar, A., and Setzer, W. N. 2014. Antileishmanial activity of the essential oil from Bixa orellana. Phytotherapy Research, 28:5:753-758.

Moreira, M. R. Ponce, A. G. Del Valle, C. E. Roura, S. I. 2005. Inhibitory parameters of essential oils to reduce a foodborne pathogen. LWT-Food Science and Technology, 38:5:565570 .

Moura, M. C. Pontual, E. V. Gomes, F. S. Napoleão, T. H. Xavier, H. S. Paiva, P. M.and Coelho, L. C. B. B. 2011. Preparations of Moringa oleifera flowers to treat contaminated water. Advances in envinronmental research, 21: 269-275.

Murphy, H. M. Corston-Pine, E. Post, Y. and McBean, E. A. 2015. Insights and Opportunities: Challenges of Canadian First Nations Drinking Water Operators. International Indigenous Policy Journal, 6:3.

Nazzaro, F. Fratianni, F. De Martino, L. Coppola, R. and De Feo, V. 2013. Effect of essential oils on pathogenic bacteria. Pharmaceuticals, 6:12:1451-1474.

NCCLS 2014. Methods for Dilution Antimicrobial Susceptibility Tests for Bacteria That Grow Aerobically; Approved Standard, Seventh Edition. NCCLS Approved Standard M7-A7 26 (2) Clinical and Laboratory Standards Institute, Wayne, PA. Print.

Oussalah, M. Caillet, S. Saucier, L. and Lacroix, M. 2007. Inhibitory effects of selected plant essential oils on the growth of four pathogenic bacteria: E. coli O157: H7, Salmonella typhimurium, Staphylococcus aureus and Listeria monocytogenes. Food control, 18:5:414-420. 
Price S. 1987 Practical Aromatherapy: how to use essential oils to restore vitality. London: Harper Thorsons Publishing.

Pimentel, D. Cooperstein, S. Randell, H. Filiberto, D. Sorrentino, S. Kaye, B. Nicklin, C. Yagi, J. Brian, J. O'hern, J. and Habas, A. 2007. Ecology of increasing diseases: population growth and environmental degradation. Human Ecology, 35:6:653-668. Print.

Prabuseenivasan, S. Jayakumar, M. and Ignacimuthu, S. 2006. In vitro antibacterial activity of some plant, essential oils. BMC complementary and alternative medicine, 6:1:39.

Public Health Agency of Canada. 2013. Estimates of Food-borne Illness in Canada. Food-borne and Water-borne Infections-Invisible Threats. http://www.phac-aspc.gc.ca/cphorsphcrespcacsp/2013/food-water_alim-eau-eng.php.

Rai, M. and Kon, K. (Eds.). 2013. Fighting Multidrug Resistance with Herbal Extracts, Essential Oils and Their Components. Academic Press.

Ramaiah, N. Kenkre, V.D. and Verlecar, X.N. 2002 "Marine Environmental Pollution Stress Detection through Direct Viable Counts of Bacteria." Water Research 36:2383-2393. Print.

Rather, M. A. Dar, B. A. Dar, M. Y. Wani, B. A. Shah, W. A. Bhat, B. A. Ganai, B.A. Bhat, K.A. Anand, R. and Qurishi, M. A. 2012. Chemical composition, antioxidant and antibacterial activities of the leaf essential oil of Juglans regia L. and its constituents. Phytomedicine, 19:13:1185-1190.

Raut, J. S. and Karuppayil, S. M. 2014. Bioprospecting of plant essential oils for medicinal uses. In Environment and Sustainable Development 59:76. Springer India. 
Richardson, S. D. Plewa, M. J. Wagner, E. D. Schoeny, R. and DeMarini, D. M. 2007.

Occurrence, genotoxicity, and carcinogenicity of regulated and emerging disinfection byproducts in drinking water: a review and roadmap for research. Mutation

Research/Reviews in Mutation Research, 636:1:178-242.

Rizzo, L. Manaia, C. Merlin, C. Schwartz, T. Dagot, C. Ploy, M. C. and Fatta-Kassinos, D. 2013. Urban wastewater treatment plants as hotspots for antibiotic resistant bacteria and genes spread into the environment: a review. Science of the total environment, 447:345-360.

Roller, S. Ernest, N. and Buckle, J. 2009. The antimicrobial activity of high-necrodane and other lavender oils on methicillin-sensitive and-resistant Staphylococcus aureus (MSSA and MRSA). The Journal of Alternative and Complementary Medicine, 15:3:275-279.

Sangwan, N. S. Farooqi, A. H. A. Shabih, F. and Sangwan, R. S. 2001. Regulation of essential oil production in plants. Plant growth regulation, 34:1:3-21.

Siddiqua, S. Anusha, B. A. Ashwini, L. S. and Negi, P. S. 2014. Antibacterial activity of cinnamaldehyde and clove oil: effect on selected foodborne pathogens in model food systems and watermelon juice. Journal of Food Science and Technology, 1:8.

Silveira, S. M. D. Cunha Júnior, A. Scheuermann, G. N., Secchi, F. L. Vieira, C. R. W. 2012. Chemical composition and antimicrobial activity of essential oils from selected herbs cultivated in the South of Brazil against food spoilage and foodborne pathogens. Ciência Rural, 42:7:1300-1306.

Sinclair, J. and Hechtman, L. 2011. Herbal Medicine. Clinical Naturopathic Medicine, 103.

Soković, M. Glamočlija, J.Marin, P. D. Brkić, D. van Griensven, L. J. 2010. Antibacterial effects of the essential oils of commonly consumed medicinal herbs using an in vitro model. Molecules, 15:11:7532-7546. 
Somaatmadja, D. Powers, J. J. and Hamdy, M. K. 1964. Anthocyanins. VI. Chelation Studies on Anthocyanins and Other Related Compoundsa. Journal of Food Science, 29:5: 655-660.

Smith-Palmer, A. Stewart, J. and Fyfe, L. 1998. Antimicrobial properties of plant essential oils and essences against five important food-borne pathogens. Letters in applied microbiology, 26:2:118-122.

Tajkarimi, M. M. Ibrahim, S. A. and Cliver, D. O. 2010. Antimicrobial herb and spice compounds in food. Food control, 21:9:1199-1218.

Teixeira, B. Marques, A. Ramos, C. Neng, N. R. Nogueira, J. M. Saraiva, J. A. and Nunes, M. L. 2013. Chemical composition and antibacterial and antioxidant properties of commercial essential oils. Industrial Crops and Products, 43:587-595.

Ternes, T. A. Joss, A. and Siegrist, H. 2004. Peer reviewed: scrutinizing pharmaceuticals and personal care products in wastewater treatment. Environmental Science \& Technology, 38:20:392A-399A.

Thomson, W. A. Schultes, R. E. 1978. Medicines from the Earth. McGraw-Hill.

Turgis, M. Han, J. Caillet, S. and Lacroix, M. 2009. Antimicrobial activity of mustard essential oil against Escherichia coli O157: H7 and Salmonella typhi. Food Control, 20:12:1073-1079.

Ultee, A. Slump, R. A. Steging, G. and Smid, E. J. 2000. Antimicrobial activity of carvacrol toward Bacillus cereus on rice. Journal of Food Protection ${ }^{\circledR}, 63: 5: 620-624$.

Ultee, A. and Smid, E. J. 2001. Influence of carvacrol on growth and toxin production by Bacillus cereus. International journal of food microbiology, 64:3:373-378. 
US EPA 2006. Guidelines for Carcinogen Risk Assessment. Risk Assessment Forum.

Washington, D.C., U.S. Environmental Protection Agency.

Walsh, C. 2003. Where will new antibiotics come from?. Nature Reviews Microbiology, 1:1:6570.

WHO 2000, Swimming Pools, Spas and Similar Recreational Water Environment. Guidelines for Safe Recreational-water Envi- ronments, vol. 2, World Health Organization, Geneva.

WHO 2011. Guidelines for drinking-water quality. World Health Organization, 216:303-4.

Wiegand, I. Hilpert, K. and Hancock, R. E. 2008. Agar and broth dilution methods to determine the minimal inhibitory concentration (MIC) of antimicrobial substances. Nature protocols, 3:2:163-175.

Winward, G. P., Avery, L. M., Frazer-Williams, R., Pidou, M., Jeffrey, P., Stephenson, T., and Jefferson, B. 2008. A study of the microbial quality of grey water and an evaluation of treatment technologies for reuse. Ecological engineering, 32:2:187-197.

Yap, P. S. X., Yiap, B. C., Ping, H. C., and Lim, S. H. E. 2014. Essential oils, a new horizon in combating bacterial antibiotic resistance. The open microbiology journal, 8:6.

Yongabi, K. A., Lewis, D. M., and Harris, P. L. 2011. A Moringa Oleifera Disinfectant-Sand Filter Integration: A Review of an Alternative Sustainable Technology for Household Water Treatment. Journal of Environmental Science and Engineering, 5:9:1100-1108. 